\begin{abstract}
UNIVERSIDADE DE SÃO PAULO
ESCOLA DE ENFERMAGEM DE RIBEIRÃO PRETO

DEPARTAMENTO DE ENFERMAGEM GERAL E ESPECIALIZADA
\end{abstract}

SUELI SOLDATI ABRANCHES

A situação ergonômica do trabalho de enfermagem em

unidade básica de saúde

Ribeirão Preto

2005 
SUELI SOLDATI ABRANCHES

A situação ergonômica do trabalho de enfermagem em unidade básica de saúde

Tese apresentada à Escola de Enfermagem de Ribeirão Preto da Universidade de São Paulo para obtenção do título de Doutor pelo Programa Pós-Graduação em Enfermagem Fundamental.

Linha de Pesquisa: Saúde do Trabalhador

Orientadora:Dr ${ }^{\mathrm{a}}$ Maria Helena Palucci Marziale

Ribeirão Preto

2005 
AUTORIZO A REPRODUÇÃO E DIVULGAÇÃO TOTAL OU PARCIAL DESTE TRABALHO, POR QUALQUER MEIO CONVENCIONAL OU ELETRÔNICO PARA FINS DE ESTUDO E PESQUISA DESDE QUE CITADA A FONTE

FICHA CATALOGRÁFICA

Abranches, Sueli Soldati

A situação ergonômica do trabalho de enfermagem em unidade básica de saúde. Ribeirão Preto, 2005.

216 p. : il. ; $30 \mathrm{~cm}$

Tese apresentada à Escola de Enfermagem de Ribeirão Preto/USP - Programa Pós-Graduação em Enfermagem Fundamental. Linha de Pesquisa: Saúde do Trabalhador

Orientadora: Maria Helena Palucci Marziale

1. Enfermagem 2. Saúde Ocupacional 3. Ergonomia 


\section{FOLHA DE APROVAÇÃO}

Sueli Soldati Abranches

A situação ergonômica do trabalho de enfermagem em unidade básica de saúde

Tese apresentada à Escola de Enfermagem de Ribeirão Preto da Universidade de São Paulo para obtenção do título de Doutor.

Linha de Pesquisa: Saúde do Trabalhador

Aprovado em:

Banca Examinadora

Prof. Dr.

Instituição: Assinatura:

Prof. Dr.

Instituição: Assinatura:

Prof. Dr.

Instituição: Assinatura:

Prof. Dr.

Instituição: Assinatura:

Prof. Dr.

Instituição: Assinatura: 


\section{DEDICATÓRIA}

Ao meu querido esposo Paulo Luiz Abranches, amigo e companheiro, pela presença constante, carinho e confiança. Incentivador permanente, que com seu amor, compreendeu e acompanhou todos os passos.

Aos meus queridos filhos Vitor, Rodrigo $e$

Débora bens de minha vida, que tornam possivel acreditar no amor, no cuidar e em um mundo melhor.

Aos meus queridos pai Reinaldo Soldati e mãe Maria de Lourdes Lucarelli Soldati (in memorian) por acreditarem, incentivarem $e$ mostrarem que só é possivel construir com dignidade e amor, sendo exemplo.

Às minhas queridas irmãs, Celeste Soldati Mol e Marta Soldati Martins, companheiras e amigas de todos os momentos.

Aos meus queridos sobrinhos Mariana, Viviane, Isabella, Luiza e José Henrique, sementes de luz que tanto amo. 


\section{AGRADECIMENTOS}

À Deus, obrigado por ter me dado coragem para enfrentar os vários momentos, saúde durante toda esta trajetória, discernimento para ir de encontro às pessoas bondosas e amigas no caminho.

À Dra. Maria Helena Palucci Marziale, minha orientadora, pela sensibilidade que sempre demonstrou ao perceber-me como gente, ser humano em constante busca. Obrigada pelo respeito $e$ por sua maneira de acompanhar a busca e a expansão de meu conhecimento. A sua amizade, disponibilidade e confiança foram os estímulos necessários para a construção do trabalho.

À Dra. Maria Lúcia do Carmo Cruz Robazzi, por seu apoio no Mestrado e por me acompanhar em todas as fases desta tese, Seu carinho, amizade, profissionalismo e acolhimento desde os primeiros momentos, permanecerão para sempre em minhas lembranças.

Aos Dra. Neuza Maria Costa Alexandre, Dra. Vanda Elisa Anches Celi, Dr. César Aléxis Galera e Dra Maria Yvone Chaves Mauro pelo saber compartilhado, pelo acolhimento e pelas contribuições marcantes nesta pesquisa.

Aos coordenadores, docentes e secretários da pósgraduação Stricto Sensu da Escola de Enfermagem de Ribeirão Preto/USP - Doutorado em Enfermagem.

Aos colegas de Doutorado, pelo prazer da troca $e$ convivência .

À Reitoria e Pró-Reitoria do Centro Universitário de Barra Mansa- UBM/RJ, pelo apoio e confiança.

Aos docentes e discentes do Curso de Enfermagem de 
Barra Mansa/RJ. pelo respeito e harmonia nos caminhos da responsabilidade na formação em enfermagem.

\section{À Secretaria de Saúde do Município de Volta Redonda} que permitiu a realização desta pesquisa, que soube perceber a contribuição que este estudo traria para seus trabalhadores e para à saúde da população.

$\grave{A}$ equipe de enfermagem participante deste estudo, que me receberam de forma solícita e desprendida, expressaram sua maneira de identificar as situações de vida e trabalho, me possibilitando conhecer a riqueza contida em suas experiências e forma de expressão.

À enfermeira Orminda por seu apoio, educação e carinho, no atendimento às solicitações feitas, mesmo com as responsabilidades no cotidiano de seu trabalho. Sempre atenta e preocupada com a equipe de enfermagem, percebeu a importância e a contribuição que esse estudo proporcionaria.

Agradeço a todos que de forma direta ou indireta contribuíram para meu crescimento como pessoa e profissional e na realização desta conquista. 
" Um homem só é grande quando junto de outros homens constrói um bem que é de todos. 


\section{RESUMO}

ABRANCHES, Sueli Soldati. A situação ergonômica do trabalho de enfermagem em unidade básica de saúde. 2005. f. Tese (Doutorado) - Escola de Enfermagem de Ribeirão Preto, Universidade de São Paulo, Ribeirão Preto, 2005.

O trabalho de enfermagem em unidades básicas de saúde é caracterizado por situações geradoras de riscos à saúde, muitas vezes desconhecidas. Esta investigação teve como objetivo analisar as condições do trabalho de enfermagem em uma unidade básica de saúde, utilizando-se o método ergonômico proposto por IIDA (1990). Os dados foram coletados no período de fevereiro a maio de 2005, utilizando-se formulários, aplicados às trabalhadoras de enfermagem, contendo variáveis relativas aos dados dos profissionais, do ambiente e postos de trabalho e à atividade do trabalho e a técnica de observação. Os resultados evidenciaram que 50\% das trabalhadoras é portadora de hipertensão arterial, 75\% está com peso acima do ideal, a maioria identifica a excessiva de tarefas demandada pela população em relação ao insuficiente número de trabalhadoras como fator predisponente de estresse e violência ocupacional que interferem na qualidade de vida no trabalho. $\mathrm{O}$ ambiente apresenta inadequação de mobiliários nos postos de trabalho, ruído e temperaturas em níveis elevados. A situação de trabalho é geradora de violência do tipo estrutural e psicológica portanto, a situação de trabalho analisada não oferece adequadas condições de trabalho as trabalhadores de enfermagem. Pode-se inferir que a situação de trabalho vivida pela enfermagem na UBS interfere na organização e qualidade de vida no trabalho em saúde coletiva, culminando na influência sobre sua saúde, desempenho e bem-estar.

Palavras-chave: enfermagem, saúde ocupacional, ergonomia 


\begin{abstract}
ABRANCHES, Sueli Soldati. The ergonomic situation of the work of nursing in basic unit of health. 2005. f. Tese (Doutorado)- Escola de Enfermagem de Ribeirão Preto, Universidade de São Paulo, Ribeirão Preto, 2005.
\end{abstract}

The work of nursing in basic units of health is characterized by generating situations of risks to the health, many unknown times. This inquiry had as objective to analyze the conditions of the work of nursing in a basic unit of health, using the ergonomic method considered by IIDA (1990). Os data they had been collected in the period of February the May of 2005, using forms, applied to the nursing workers, I contend changeable relative to the data of the professionals, the environment and ranks of work and to the activity of the work and the technique of comment. The diligent results had evidenced that $50 \%$ are carrying of arterial hipertension, $75 \%$ are with do above ideal weight, the majority identifies the extreme one of tasks demanded population in relation the insufficient number of workers as predisponent factor of stress and occupational violence that intervenes na quality of life no work. The environment presents inadequacion of movable in the work ranks, noise and temperatures in high levels. The work situation is generating of violence of the structural type and psychological therefore, the analyzed situation of work does not offer to adequate conditions of work the nursing workers. It can be inferred that the situation of work lived for the nursing in the UBS interfe in the organization and quality of life in the work in collective health, culminating in the influence on its health, performance and well-being.

Keywords: nursing; occupational health; human engineering 


\section{RESUMEN}

ABRANCHES, Sueli Soldati. La ergonómico situación del trabajo del cuidado en la unidad básica de la salud. 2005. f. Tese (Doutorado) - Escola de Enfermagem de Ribeirão Preto, Universidade de São Paulo, Ribeirão Preto, 2005.

El trabajo del cuidado en unidades básicas de la salud es caracterizado generando situaciones de los riesgos a la salud, muchas veces desconocidas. ¿Esta investigación tenía como objetivo para analizar las condiciones del trabajo del cuidado en una unidad básica de la salud, usando el método ergonómico considerado por IIDA (los datos 1990).Os que habían sido recogidos en el período de febrero el mayo de 2005, usando las formas, aplicadas a los trabajadores del oficio de enfermera, yo afirman cambiable concerniente a los datos de los profesionales, del ambiente y de filas del trabajo y a la actividad del trabajo y a la técnica del comentario. Los resultados diligentes habían evidenciado que los das del 50\% son el llevar de hipertension arterial, el 75\% están con hacen sobre peso ideal, la mayoría identifica el extremo de población exigida las tareas del pela en el número escaso del ao de la relación de trabajadores como factor predisponent del estresse y de la violencia ocupacional que interviene calidad del na de la vida ningún trabajo. El ambiente presenta inadequacion del mueble en las filas, el ruido y las temperaturas del trabajo en altos niveles. La situación de trabajo es generación de la violencia del tipo estructural y psicológica por lo tanto, la situación analizada del trabajo no ofrece a las condiciones adecuadas del trabajo a trabajadores del oficio de enfermera. Puede ser deducido que la situación del trabajo vivió para el oficio de enfermera en el influencia de UBS en la 
organización y la calidad de la vida en el trabajo en salud colectiva, culminando en la influencia en su salud, funcionamiento y bienestar.

Palabras-claves: enfermería; salud ocupacional; ingeniería humana 


\section{LISTA DE TABELAS}

Tabela 1 Dados biográficos dos profissionais de enfermagem----------- 100

Tabela 2 Respostas dos profissionais de enfermagem na UBS quanto às tarefas em cada jornada de trabalho. Volta Redonda/RJ, 2005--- 117

Tabela 3 Respostas dos profissionais de enfermagem na UBS em relação aos materiais utilizados para executar as tarefas. Volta Redonda/RJ. 2005

Tabela 4 Respostas dos profissionais de enfermagem na UBS em relação à adequação do ambiente de trabalho. Volta Redonda/RJ.2005.

Tabela 5 Respostas dos profissionais de enfermagem na UBS em relação à organização do trabalho. Volta Redonda/RJ.2005-- 


\section{LISTA DE QUADROS}

Quadro 1 Dados antropométricos das trabalhadoras de enfermagem da UBS.Volta Redonda -RJ.2005

Quadro 2 Distribuição do tempo de serviço na enfermagem e na unidade. Volta Redonda/RJ, 2005

Quadro 3 Valores de temperaturas aferidas nas salas de atuação da equipe de enfermagem da UBS. Volta Redonda/RJ.2005-----

Quadro 4 Valores médios de iluminação (em LUX) obtidos nas salas de atuação da equipe de enfermagem da UBS. Volta Redonda/RJ.2005-

Quadro 5 Valores médios de ruídos em $\mathrm{dB}(\mathrm{A})$ aferidos nas salas de atuação da equipe de enfermagem da UBS. Volta Redonda /RJ.2005

Quadro 6 Tempo gasto (em segundos) pelo auxiliar de enfermagem na sala de vacinação para execução desta atividade durante o turno da tarde (vacina BCG)

Quadro 7 Tempo gasto (em segundos) pelo auxiliar de enfermagem na sala de vacinação para execução desta atividade durante o turno da tarde (vacina Hepatite B) 


\section{LISTA DE FIGURAS}

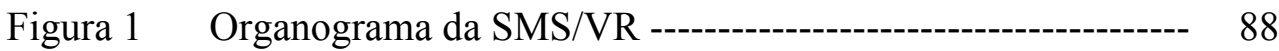

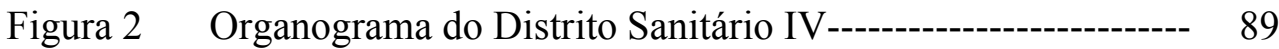

Figura 3 Condições de saúde dos profissionais de enfermagem na UBS-- 109

Figura 4 Respostas dos profissionais de enfermagem na UBS em relação ao treinamento ao iniciar as atividades na UBS. Volta Redonda/RJ.2005--------------------------------------------- 119

Figura 5 Respostas dos profissionais de enfermagem na UBS em relação 120 à educação em serviço. Volta Redonda/RJ.2005

Figura 6 Planta Física da Unidade Básica de Saúde. Volta Redonda, 2005

Figura 7 Sala de ginecologia ------------------------------------------------- 132

Figura 8 Cadeira não planejada segundo as recomendações ergonômicas-

Figura 9 Cadeira e mesa não planejadas segundo as recomendações ergonômicas induzindo à má postura corporal pelos trabalhadores-

Figura 10 Visão da sala de nebulização em relação à bancada de pia e outros equipamentos

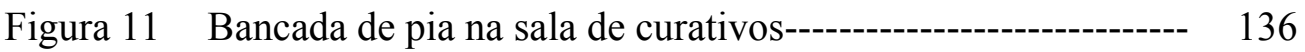

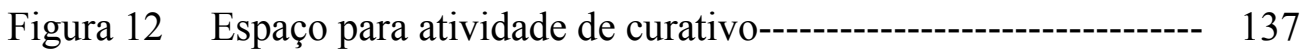

Figura 13 Inadequação quanto às recomendações ergonômicas da mesa 
e cadeira-

Figura 14 Acondicionamento do lixo da sala de vacinação----------------- 139

Figura 15 Preparo do material em sala de esterilização-------------------- 141

Figura 16 Mesa e cadeira em condições não recomendadas em ergonomia----------------------------------------------------------------- 14

Figura 17 Cadeira sem encosto e em condições inseguras para o uso--- 142

Figura 18 Sala de distribuição de medicamentos---------------------------- 143

Figura 19 Prateleiras e altura inadequada------------------------------------ 143

Figura 20 Janela para distribuição de medicamentos----------------------- 145

Figura 21 Aplicação de vacina BCG e a postura adotada pela profissional 159

Figura 22 Preparo da vacinação na posição em pé ------------------------- 162

Figura 23 Posições adotadas (em minutos) pelo auxiliar de enfermagem 164 na sala de vacinação

Figura 24 Registros durante a vacinação na posição inclinada e de pé--- 165 
Resumo

Abstract

Resumen

Lista de Tabelas

Lista de Quadros

Lista de Figuras

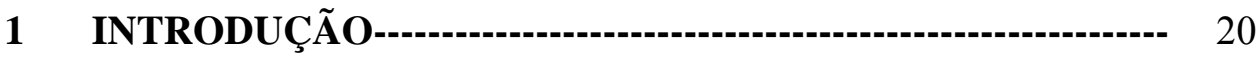

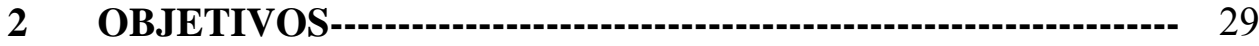

2.1 GERAL------------------------------------------------------------------------ 29

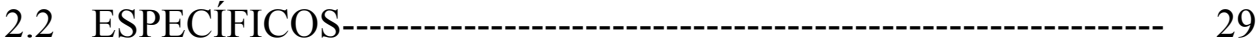

3 REFERENCIAL TEÓRICO-METODOLÓGICO------------ 30

3.1 AS POLÍTICAS DE SAÚDE, O PROCESSO DE TRABALHO EM SAÚDE COLETIVA E A UNIDADE BÁSICA DE SAÚDE-- 30

3.2 O TRABALHO DE ENFERMAGEM E AS DIMENSÕES DO

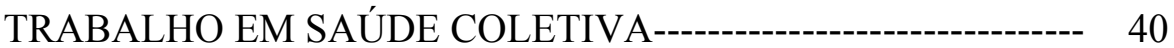

3.3 A VIOLÊNCIA NO TRABALHO DO SETOR DE SAÚDE ------- 56

3.4 ABORDAGEM ERGONÔMICA DO TRABALHO----------------- 65 
4 MÉTODO-- 78

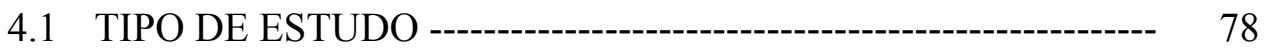

4.2 CENÁRIO--

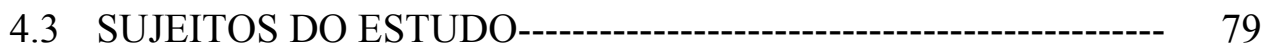

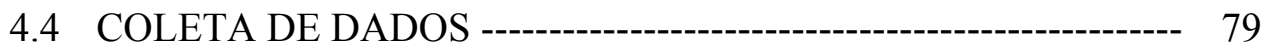

4.5 INSTRUMENTOS DE COLETA DE DADOS --ב-י-:--- 82

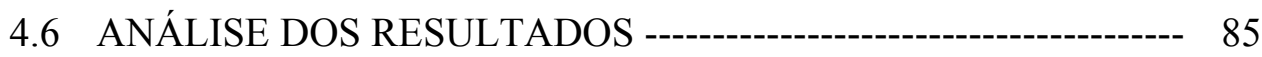

5 ANÁLISE E DISCUSSÃO DOS RESULTADOS---י--:--- 87

5.1 CONDIÇÕES DE VIDA E TRABALHO EM ENFERMAGEM NA UBS 88

OS TRABALHADORES DE ENFERMAGEM E OS FATORES

5.2 DETERMINANTES DAS CONDIÇÕES DE TRABALHO ------- 100

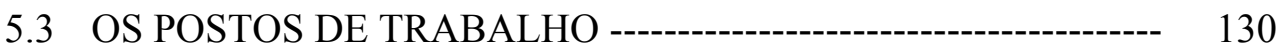

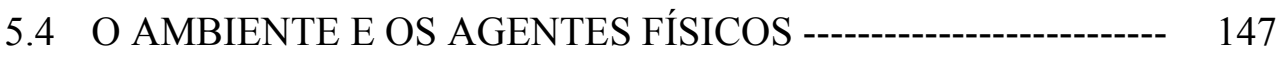

5.5 A ATIVIDADE DO TRABALHO E OS FATORES ERGONÔMICOS ASSOCIADOS - 154

6 RECOMENDAÇÕES --

7 CONCLUSÕES - 


\section{APÊNDICES}

APÊNDICE A - Termo de consentimento livre e esclarecido APÊNDICE B - Roteiro de entrevista com a gerente APÊNDICE C - Roteiro de entrevista com o profissional de enfermagem da UBS

APÊNDICE D - Ambiente físico de trabalho APÊNDICE E - Postos de trabalho APÊNDICE F - Folha de registro das atividades de trabalho APÊNDICE G - Rotina da sala de vacinação

\section{ANEXOS}

A - Ofício de autorização para realização da pesquisa à SMS

B - Autorização concedida para a Pesquisa

C - Autorização do Comitê de Ética em Pesquisa/EERP/USP- 


\section{1- Introdução}

O trabalho é considerado por muitos estudiosos como uma forma elevada de socialização humana, representando muitas vezes um aprendizado e um contato permanente entre as pessoas. Seu significado é de compreensão dialética, propicia a criatividade, a imaginação, o progresso para alguns e, para outros, o sofrimento, a insatisfação e a doença (MIELNIK, 1976, p. 49)

Sob este aspecto, pode afetar o estado de saúde do homem. Sua forma de organização e concepção pode expô-lo aos riscos provenientes do ambiente e das atividades laborais.

Dentre as diferentes atividades de trabalho exercidas pelos homens, o estudo, ora apresentado, está direcionado à situação de trabalho dos serviços de saúde, em especial ao trabalho de enfermagem, considerando que tais serviços requerem uma organização complexa. Neles, a enfermagem é a que concentra a maior força de trabalho em saúde e é a que mais está exposta aos riscos provenientes de sua ocupação.

Segundo Leopardi (1999, p. 60), a enfermagem, em sua área de atuação profissional, utiliza-se dos elementos do processo terapêutico do cuidado com seres humanos, nos quais estão implicadas as dimensões da vida social, afetiva, psicológica e espiritual, e às quais direcionam o sentido de bem-estar individual e coletivo das pessoas assistidas. Os profissionais de enfermagem executam um trabalho cuja finalidade corresponde ao desejo de manutenção da saúde das pessoas. 
A enfermagem atua visando o cuidado do outro, que pode ser o paciente, o usuário, os familiares e a população que necessita de seus cuidados. Entretanto, nem sempre esta lógica é aplicada à sua própria situação de saúde e mais precisamente à sua situação laboral de trabalho. Portanto, faz-se necessário reconhecer e analisar as situações de trabalho que interferem na sua qualidade de vida e de saúde.

Como profissional, precisa despertar sua consciência para os seus direitos e deveres e necessita conhecer a natureza e as condições do ambiente ocupacional, para agir sobre os determinantes do sofrimento e do adoecimento provenientes deste local.

A equipe de enfermagem, conforme a Lei 7.498, de 25 de julho de 1986, é composta por enfermeiros, técnicos de enfermagem, auxiliares de enfermagem e parteiras (ASSOCIAÇÃO BRASILEIRA DE ENFERMAGEM, 1987), constituindo-se numericamente o maior grupo de profissionais do setor saúde tendo composição predominantemente feminina.

Um número significativo destes profissionais atua em mais de um emprego, caracterizando, nestes casos, a dupla e às vezes tripla jornada remunerada, em decorrência do fato dos salários recebidos estarem em sua maioria, aquém de seu nível de qualificação. Entre as mulheres, grande parte assume também encargos domésticos (ROBAZZI; MARZIALE, 1999, p. 333).

Preocupados com esta situação, a Organização Mundial de Saúde e a Organização Internacional do Trabalho (OMS; OIT, 1976) normatizam a assistência em saúde e a Organização Internacional do Trabalho (OIT; OMS, 
1977) formula orientações, que vem ao encontro das questões de saúde. Assim, vêm atuando, historicamente sobre as questões de saúde, em especial sobre a saúde da equipe de enfermagem, com o objetivo de garantir-lhe melhores condições de vida e de trabalho.

Esse esforço em conjunto tem primado pela melhoria de ações voltadas para o exercício da prática profissional. Neste sentido, estas organizações vêm interagindo com diferentes segmentos sociais, com o intuito de promover a realização de convenções que serão posteriormente ratificadas em muitos países e constituem-se em tratados internacionais.

Ainda sobre a enfermagem, os profissionais exercem suas atividades em locais, nos quais a insalubridade é evidente e há falta de recursos humanos e materiais (ROBAZZI; MARZIALE, 1999, p. 335). Entre estes locais, destacam-se as Unidades Básicas de Saúde (UBS) nas quais expressiva quantidade de trabalhadores de enfermagem atua.

No atual contexto sócio-político e econômico do Brasil, sérias dificuldades são enfrentadas no setor saúde, no que se refere à qualidade da assistência prestada à população e as condições oferecidas neste setor. Observa-se, em particular, na UBS, os baixos salários, a demanda intensa da clientela em relação às atividades assistenciais da enfermagem e as exigências do trabalho, que favorecem atos de violência no trabalho, particularmente dos usuários em relação aos trabalhadores. O ritmo intenso e a repetitividade das tarefas os expõem aos riscos que, reconhecidos como físico/mecânicos, psicossociais, químicos, biológicos e especialmente ergonômicos, podem ocasionar-lhes desgaste e adoecimento, em 
função das condições laborais.

Para Marziale e Carvalho (1998), as condições de trabalho e os riscos ocupacionais podem ser estudados por diferentes abordagens, dentre elas a ergonômica. Para a ergonomia, as condições de trabalho são representadas por um conjunto de fatores interdependentes que atuam direta ou indiretamente na qualidade de vida das pessoas e nos resultados do próprio trabalho. E o homem, a atividade e o ambiente de trabalho são os componentes da situação de trabalho, que devem ser analisados.

De acordo com a International Ergonomics Association (IEA) (2000), ergonomia é a disciplina científica que trata da compreensão das interações entre os seres humanos e os outros elementos de um sistema.

A ergonomia nasceu da necessidade de responder às questões importantes levantadas por situações de trabalho insatisfatórias (WISNER, 1994, p. 87). Entre estas situações, destaca-se o trabalho de enfermagem, em relação aos seus postos de trabalho, suas atividades e ambiente laboral.

Os estudos ergonômicos têm evidenciado o estresse e os problemas osteomusculares mais freqüentes na enfermagem, como conseqüência das más condições de trabalho, o que interfere em sua saúde, em sua disposição para o trabalho e na qualidade dos cuidados prestados por estes profissionais. Esta afirmativa leva em consideração que a qualidade do cuidado prestado, em geral, mantém uma relação direta com os problemas de saúde dos executores das atividades, o que contribui para o entendimento de que existem fatores bio-psicosociais que interferem no trabalho de enfermagem (MAURO; CUPELLO, 2001). 
Os estudos em ergonomia têm se realizado em sua maioria no setor hospitalar. No entanto a UBS, que também compõe a estrutura organizacional do sistema de saúde. Neste local, há atividades realizadas em sua maioria pela equipe de enfermagem, que merecem a atenção pela complexidade das ações programadas e as circunstâncias laborais, ou seja, organização do trabalho, tarefas repetitivas, mobiliário inadequado, planta física restrita, comunicação inadequada, falta de apoio e treinamento da equipe, ausência de recursos materiais e humanos para execução do número de atividades que realizam e problemas osteomusculares aos quais se encontram sujeitos os membros desta equipe.

O trabalho nos serviços de saúde, dentre os quais o hospital e a unidade de saúde, os problemas são mais evidenciados, porque se lida diretamente com pessoas portadoras de doenças e com substâncias químicas.

A trajetória como docente das disciplinas de saúde e trabalho e administração aplicada à enfermagem na graduação em enfermagem, bem como coordenadora e docente do curso de vigilância em saúde em nível de PósGraduação Lato-sensu, oferecido no Centro Universitário de Barra Mansa do Estado do Rio de Janeiro - este em parceria com o Ministério da Saúde (MS) -, permitiu ampliar o entendimento sobre a saúde dos trabalhadores e sobre a saúde coletiva, uma vez que compartilhou materiais pedagógicos atualizados do MS, com a participação efetiva dos discentes que eram profissionais provenientes dos serviços públicos das secretarias de saúde da região.

O motivo pela escolha do referencial no presente estudo deu-se pela aplicabilidade da ergonomia com a natureza do problema e com a aproximação 
destes conhecimentos obtidos no Curso de Especialização em Ergonomia, que foi realizado na Universidade Federal do Rio de Janeiro (UFRJ), onde se obteve o instrumento para aprofundar neste contexto. Ao cursar esta especialização, realizou-se um estudo que se constituiu da análise ergonômica de uma UBS, permitindo observar a enfermagem no contexto dessa Unidade. Os trabalhadores desta profissão apresentavam queixas de dores lombares, cefaléias e absenteísmos, os quais estavam relacionados aos fatores psicossociais enfrentados pelos profissionais, entre eles as questões de ordem familiar e socioeconômica, como a baixa renda familiar e o custo para manutenção da sua própria saúde e de seus familiares e, ainda, da qualidade de vida.

Também foram apontadas queixas sobre agressões verbais de usuários insatisfeitos com os trabalhadores de enfermagem, muitas vezes pelo tempo de espera para o atendimento.

$\mathrm{Na}$ atividade de docência, houve relatos de profissionais de enfermagem sobre as agressões físicas e ameaças de homicídio à equipe, em decorrência da violência social vivida pela população, mas que também os afetava. Eles eram ameaçados por pessoas envolvidas com atos criminosos e ilegais que, de forma inapropriada, exigem a atenção e os cuidados dos profissionais sob condições agressivas, sendo estes problemas indicativos de violência laboral.

Esta situação provoca tensão e frustração nos trabalhadores e remete à responsabilidade institucional dos serviços de saúde, em relação à saúde e integridade dos profissionais - o que constitui um indicador institucional que poderia ser mais bem compreendido. 
Segundo a Organização Mundial da Saúde (2002)

a violência é o uso intencional da força física ou do poder, real ou por ameaça, contra a própria pessoa, contra outra pessoa, ou contra um grupo ou comunidade que pode resultar em ou tem alta probabilidade de resultar em morte, lesão, dano psicológico, alterações do desenvolvimento ou de privação.

A violência ocupacional está constituída por incidentes nos quais os trabalhadores sofrem abusos, ameaças ou ataques em circunstâncias relacionadas com o seu trabalho, incluindo o trajeto de ida e volta que colocam em perigo, implícita ou explicitamente, sua segurança, seu bem estar ou sua saúde.

Vários fatores podem interferir na violência ocupacional tais como os aspectos individuais dos trabalhadores (personalidade, formação); aspectos relacionados ao próprio ambiente de trabalho (estratégia organizacional, recursos humanos e materiais, sistema de comunicação); além de aspectos ligados à clientela atendida (CEZAR, 2005).

Assim, a inadequação de postos de trabalho pode ser considerada um fator de violência ocupacional que impossibilita o trabalhador de se sentir seguro nestes locais, fato que pode favorecer a não adaptação às condições de trabalho, adoecimento pelo trabalho e baixa produtividade.

Foram detectadas dificuldades de estudantes e profissionais de enfermagem em reconhecerem, no desempenho de suas atividades práticas, situações possíveis de comprometimento de sua saúde.

Assim, o objeto deste estudo é a situação ergonômica do trabalho em enfermagem em UBS, uma vez que a atenção da maioria dos pesquisadores tem sido voltada ao hospital e a unidade de saúde merece ser mais detalhada em seu 
processo e condições de trabalho.

O Ministério da Saúde (BRASIL.MS., 2005, p. 61) definiu os princípios e diretrizes da política de saúde ocupacional para o trabalhador do Sistema Único de Saúde (SUS). Conceitua a saúde ocupacional do trabalhador como um valor social público, para o qual concorrem dimensões sociais, políticas, econômicas, ambientais e organizacionais que demandam o estabelecimento de políticas, planos, programas, projetos e ações de promoção e proteção da saúde, de controle e vigilância dos riscos advindos das condições e dos ambientes e processos de trabalho, de prevenção e detecção de agravos, de recuperação e reabilitação da saúde e da capacidade de trabalho e qualidade de vida.

Os profissionais que atuam em UBS são trabalhadores do SUS. Deste modo, fazem-se necessários estudos que subsidiem a implantação desta política. O estudo ergonômico permite detalhar a situação de trabalho da enfermagem e esclarecer as correlações entre o adoecimento, baixo desempenho e dimensionamento inadequado da equipe. $\mathrm{O}$ estudo busca contribuir com projetos e programas de atenção à saúde ocupacional dos trabalhadores.

Pretende-se contribuir para a saúde e melhores condições de trabalho em enfermagem, trazendo à discussão os seus aspectos e dimensões, bem como contribuir para:

- o ensino de enfermagem, incrementando estudos nesta temática, especialmente despertando para os aspectos ergonômicos do trabalho;

- o processo de trabalho da equipe de enfermagem em saúde coletiva; 
- o cuidado de enfermagem, enfocando as possibilidades de ações voltadas para o bem estar, conforto e qualidade de vida e trabalho dos trabalhadores. 


\section{Objetivos}

\section{Geral}

- Analisar as condições ergonômicas do trabalho de enfermagem em uma Unidade Básica de Saúde.

\section{Específicos}

- Identificar a demanda de análise ergonômica;

- Identificar as características dos trabalhadores de enfermagem que atuam na unidade básica de saúde;

- Avaliar as condições de vida e trabalho;

- Levantar os determinantes de violência laboral;

- Caracterizar o ambiente de trabalho e postos de trabalho da equipe de enfermagem da UBS;

- Analisar uma atividade efetivamente realizada pelos profissionais de enfermagem na UBS. 


\section{Referencial Teórico-Metodológico}

\subsection{As Políticas de Saúde, o processo de trabalho em saúde coletiva e a Unidade Básica de Saúde}

Desde a origem do Estado brasileiro, o sistema de saúde tem sido objeto de um permanente debate e cenário de fatos históricos marcantes, em busca de seu avanço e melhorias. Neste contexto, destaca-se a Reforma Sanitária e $8^{\mathrm{a}}$ Conferência Nacional de Saúde (BRASIL, MS., 1986) que determinaram mudanças substanciais no sistema de saúde brasileiro.

No Brasil, o processo de reforma no setor saúde foi impulsionado pelo Movimento de Reforma Sanitária, parte do processo de redemocratização do país, que propunha expressar um projeto político de mudança de concepção e de suas práticas em saúde. Com este movimento, houve uma ampliação do conceito de saúde que passou a ser um direito do cidadão e dever do Estado, decorrente da expansão estatal, da elaboração da legislação sanitária a partir de 1990 e da reorganização dos serviços de saúde, buscando instituir um novo modelo assistencial centrado no usuário, na população, voltado ao atendimento integral à saúde, baseado na promoção da saúde e na melhoria da qualidade de vida (WITT, 2005, p. 26).

A reforma sanitária, conforme ressalta Mendes (1995), pode ser conceituada como um processo modernizador e democratizante de transformação nos âmbitos político-jurídico, político-institucional e político operativo. Para dar conta da saúde dos cidadãos, entendida como um direito universal e suportada por 
um Sistema Único de Saúde-SUS, ela abordou três aspectos fundamentais. O primeiro foi a saúde com um conceito mais amplo, resultante das condições de alimentação, moradia, educação, renda, meio ambiente, trabalho, transporte, emprego, lazer, liberdade, acesso e posse de terra e acesso aos serviços de saúde. É assim, o resultado das formas de organização social da produção. O segundo aspecto foi a saúde como direito de cidadania e dever do Estado. Para que isto pudesse ocorrer, definiu o Estado como regulador público, responsável pela garantia desse direito de cidadania. E o terceiro aspecto, como elemento estratégico, propôs uma profunda reformulação do Sistema Nacional de Saúde, com a constituição de um Sistema Único de Saúde - SUS que tivesse como princípios a universalidade, a integralidade das ações, a descentralização com mando único em cada instância federativa e a participação popular.

A $8^{\text {a }}$ Conferência Nacional de Saúde constituiu o momento de formatação político-ideológica do projeto da reforma sanitária brasileira.

Movimentos nos campos político, ideológico e institucional, desde o início dos anos setenta, confluíram para esse acontecimento, que se diferiu das demais conferências realizadas anteriormente, por duas características principais. Uma é o seu caráter democrático, pela significativa representatividade de delegados de todas as forças sociais interessadas na questão saúde, e outra, ligada à primeira, refere-se a sua configuração como processo social que começa com conferências municipais e estaduais até chegar à nacional (MENDES, 1995). 
Para Witt (2005, p. 26), foram vários os avanços produzidos por esta reforma, devido à amplitude e profundidade das mudanças que determinou. Seu tortuoso processo de implantação valorizou certos componentes do sistema de saúde, tais como o financiamento, a gestão, a organização e a infra-estrutura. Em relação ao sistema de financiamento do sistema de saúde, avanços importantes foram obtidos a partir da operacionalização dos princípios e diretrizes da Norma Operacional Básica (NOB) do SUS EM 1996, com a implantação do Piso de Atenção Básica $(\mathrm{PAB})$, com transferência regular e automática dos recursos federais para os municípios habilitados, proporcionando maior autonomia para a execução das ações e atividades de atenção básica consideradas de responsabilidade municipal.

A descentralização das ações e serviços de saúde no Brasil tem assumido distintas configurações, pela via da municipalização e pela via da distritalização (ROUQUAYROL; ALMEIDA FILHO, 1999). A municipalização da saúde implica na desconcentração dos serviços e descentralização da gestão. Já a distritalização representa um processo político-organizativo de reorientação do sistema de saúde, com ênfase no nível local, capaz de facilitar a implantação e o desenvolvimento de modelos assistenciais alternativos na construção do SUS.

No campo da legislação, encontram-se as Portarias do Ministério do Trabalho, as deliberações do Conselho Nacional de Saúde, as Leis Orgânicas de Saúde e os relatórios finais das Conferências Nacionais de Saúde. As Conferências Municipais de Saúde e os Conselhos Municipais de Saúde são instâncias 
colegiadas do SUS em cada esfera do governo, por expressa disposição legal. Os Conselhos têm caráter deliberativos, cabendo-lhes a formulação de estratégias e o controle da política de saúde, cujas decisões são homologadas pelo chefe do poder legalmente constituído (BRASIL, MS., 2005, p. 24)

A prestação de serviços de saúde tem se caracterizado predominantemente pela ênfase às ações curativas, com um modelo centrado na atenção hospitalar e baixa prioridade para os serviços de promoção da saúde e de prevenção de doenças.

$\mathrm{Na}$ organização dos serviços de saúde, o hospital constitui um complexo centro de atendimento que se destina à assistência em nível terciário (tratamento e reabilitação) das pessoas acometidas por doenças ou acidentes. A Unidade Básica de Saúde (UBS) representa um outro componente na estrutura de organização do sistema de saúde, no qual se desenvolve a atenção primária em saúde, representando o primeiro contato do indivíduo com o complexo sistema de atendimento em saúde, para a resolução de problemas de saúde que se apresentem.

Neste sentido, Nemes Filho (2000, p. 279) remete à reflexão de que as políticas de saúde consubstanciavam-se no padrão de assistência que privilegiava as práticas curativas, individuais e especializadas. O processo de reforma política e administrativa possibilitou a configuração de uma mudança assistencial e na organização dos serviços de saúde pública. A proposta de reorganização concebia a existência da rede básica de serviços de saúde, hierarquizada em relação à complexidade tecnológica em nível primário, secundário e terciário. Assim, o 
nível primário funcionaria como porta de entrada do sistema oferecendo cuidados básicos em saúde, incluindo a atenção integral à saúde, e referenciando os casos mais complexos para os demais níveis da rede de saúde.

Este modelo assistencial exige uma participação ativa da equipe de saúde das unidades básicas de saúde, quer na incorporação do instrumental utilizado para a tarefa, quer na relação intra e extra-setorial exigida para o equacionamento dos problemas identificados (NEMES FILHO, 2000, p. 285)

De acordo com os dados da Secretaria de Estado de Saúde do Rio de Janeiro, há 28 Unidades Próprias (16 hospitais, 7 institutos, 2 postos de atendimento médico -PAM-, 1 laboratório, 1 centro psiquiátrico e 1 centro de tratamento de adictos) localizadas no Estado do Rio de Janeiro. Estas Unidades da Rede Estadual fazem parte do SUS - Sistema Único de Saúde (disponível em http://www.saude.rj.gov.br).

No município de Volta Redonda/RJ, há seis hospitais (conveniados ao SUS), vinte UBS e seis módulos de Saúde da Família (disponível em http://www.portalvr.com/sms) .

Segundo Schraiber; Nemes; Mendes (2000, p. 29), quando lidamos com a organização de serviços, as necessidades de saúde são os aspectos mais importantes, pois suscitam os serviços de saúde e embasam a configuração geral de sua estrutura. A UBS destina-se ao atendimento das necessidades básicas em saúde. Pensar em assistência de saúde é pensar em seu caráter genérico e reconhecer sua complexidade.

Andrade e Adami (1996) destacam que o sistema de saúde tem a função 
primordial de proporcionar bem estar à comunidade, funcionando como um sistema aberto em constante inter-relação com o ambiente que o cerca. Neste sentido, se configura a UBS, com a oferta de serviços de saúde que visam a promoção, a proteção e a recuperação da saúde da coletividade.

A atenção primária em saúde tem sido associada a uma assistência de baixo custo, um serviço simples que requer poucos equipamentos. No entanto, as enormes dificuldades na extensão dos serviços, ou até mesmo para manter a cobertura assistencial, torna este serviço mais complexo do que se supunha (SCHRAIBER; NEMES; MENDES, 2000, p. 34).

As situações assistenciais em UBS quase sempre podem ser conceituadas como casos epidemiologicamente complexos. Esta é uma complexidade que se transfere para o trabalho profissional, mesmo em situações clínicas (SCHRAIBER; NEMES; MENDES, 2000, p. 35).

O trabalho em UBS inclui demandas sanitárias como o saneamento do meio, o acompanhamento do desenvolvimento e crescimento da criança e adolescente, a imunização, o planejamento familiar, a informação e orientação em saúde, que geram ações em saúde individual e coletiva, porém também geram demandas relacionadas às ações clínicas, entre estas a consulta de enfermagem que envolve a prevenção, a profilaxia e o tratamento de doenças de caráter clínico e epidêmico.

Este contexto exige para sua adequada compreensão sofisticada síntese de saberes e complexa interação de ações individuais e coletivas, curativas e preventivas, assistenciais e educativas (NEMES, 1990). 
Segundo o mesmo autor, este conjunto de ações envolve atuação sanitária e um trabalho complexo. Os requisitos assistenciais de uma Unidade Básica de Saúde serão os de alta capacidade resolutiva e ao mesmo tempo alta sensibilidade diagnóstica para atuar corretamente nas demandas primárias e propor encaminhamentos adequados ao interior do complexo sistema de saúde.

O trabalhador de UBS representa hoje um grande desafio organizacional, no sentido de que a assistência exige inovação tecnológica e deve ser realizada em seu sentido mais global. Como avanços tecnológicos, são apontadas a integralização das ações e uma visão mais ecológica, constituindo a assistência integral em saúde coletiva (SCHRAIBER; NEMES; MENDES, 2000, p. 44).

Nemes (1990) ressalta que estudos nesta concepção de organização permitem aprender o técnico e o social do trabalho, encontrando na prática $o$ representante tecnológico da dimensão ético-política da vida social no trabalho. Configura, então, um posicionar-se diante dessas tecnologias, permitindo criticar e inovar a dimensão técnica das práticas.

O trabalho de UBS vem se modificando, mediante a adoção de saberes e modelos organizacionais modernos e de produção de serviços, que implicam nas práticas de trabalho e na formação e qualificação dos trabalhadores.

Merhy (2002, p. 39) reflete que vários estudiosos do movimento sanitário vêm procurando equacionar a construção de modelos de atenção à saúde, no nível dos estabelecimentos e das redes de serviços, no terreno da gestão organizacional e do trabalho, mostrando que, para superar o modelo capitalista, devem constituir-se em organizações de saúde gerenciadas de modo mais coletivo. Os processos de 
trabalho devem ser cada vez mais partilhados, que permitam construir cotidianamente vínculos e compromissos estreitos entre os trabalhadores e os usuários nas formulações das intervenções tecnológicas em saúde, conforme suas necessidades individuais e coletivas.

No interior deste processo de trabalho, o trabalhador de saúde se encontra com o usuário, dirigindo-lhe ações e atenção no ato de cuidar. Estabelece-se entre eles um espaço que Merhy (2002, p. 57) denomina de intercessor que sempre existirá nos seus encontros. Reconhecer a existência desse processo singular é descobrir o tipo de interseção que se constitui e os distintos motivos que operam em seu interior.

Assim, ressalta que no processo de trabalho em saúde há um encontro do agente produtor com suas ferramentas (conhecimentos, equipamentos, tecnologias em geral) com o agente consumidor, em que se revela ou não a busca de realização e de efetiva interseção partilhada.

Neste cenário, ocorrem múltiplas e complexas interações, visíveis e invisíveis, que se manifestam no dia-a dia dos locais de trabalho, conduzindo a sempre refletir sobre as possibilidades e os limites das negociações que possam ocorrer (FREITAS, 2002, p. 1161).

Para Wunsch Filho (2002, p. 1157), os elementos que regem as negociações cotidianas fixam sua análise no contraste de interesses conflitantes entre trabalhadores e gerência. $\mathrm{O}$ mesmo autor ressalta que a liberdade individual é importante para que tenham livre expressão e possam agir de forma mais criativa. A liberdade participativa no mundo do trabalho requer um grau de instrução e o 
conhecimento sobre a organização e os processos de trabalho.

Assim, a prevenção de agravos à saúde do trabalhador deve ocorrer por meio do replanejamento do trabalho, via negociações cotidianas para reconduzir o trabalhador à gerência de sua saúde (WUNSCH FILHO, 2002, p. 1158)

Destaca-se a ênfase que se deu às questões de Recursos Humanos em saúde na II Conferência Nacional de Recursos Humanos que afirmou que as oportunidades de capacitação são escassas. Os trabalhadores convivem no mesmo local de trabalho e com as mesmas funções, com salários profundamente desiguais. Não existe, na maioria, um plano de carreira, cargos e salários compatíveis com as responsabilidades, riscos e encargos inerentes ao processo de trabalho da área de saúde. Esta situação conduz a uma enorme e explicável desmotivação dos profissionais de saúde e ao descompromisso ético e social com os usuários e com o serviço público. Os trabalhadores querem assumir o seu papel de protagonista na transformação do setor (BRASIL, 2003, p. 24).

Com o objetivo de contribuir para uma gestão de qualidade que possibilite a valorização do trabalho no SUS como instrumento essencial da atenção à saúde e a criação de vínculo dos trabalhadores com a população e os serviços de saúde pública, o Conselho Nacional de Saúde Pública publica, em 2005, a edição revisada e atualizada dos "Princípios e Diretrizes para a Gestão do Trabalho no SUS (NOB/RH/SUS) aprovados como Política Nacional, por meio da Resolução $n^{\circ} 330$ de 4 de novembro de 2004. Espera-se, por meio de sua implementação, valorizar o trabalhador e promover o trabalho interdisciplinar e multissetorial (BRASIL, 2005, p. 9) 
A publicação citada tem o mérito de ter sido elaborada de forma participativa, em um processo democrático e descentralizado, com negociações entre trabalhadores e gestores, mediadas por outros atores que fazem o Controle Social do SUS nas Conferências e no Conselho Nacional de Saúde.

Os recursos humanos no setor saúde constituem a base para a viabilização e implementação dos projetos, das ações e serviços de saúde disponíveis para a população. A utilização dos avanços tecnológicos e da alta tecnologia não substituirá a atuação de um profissional de saúde na função essencial de atendimento àqueles que necessitam de atenção (BRASIL, 2003, p. 17).

A enfermagem participa, como integrante deste sistema, acompanha a mudança, que se reflete na organização de seu trabalho, o que demanda implicações sobre as suas dimensões e os determinantes, que serão abordados no próximo capítulo. 


\subsection{O Trabalho de Enfermagem e as dimensões do trabalho em saúde coletiva}

A enfermagem tem suas origens e atuações essencialmente voltadas para a prática de cuidados ao indivíduo, à família e à população que dela necessitam.

Neves (2002) argumenta que o cuidar tem recebido diferentes significados, tais como o cuidar como processo, atitude, afeto, característica humana, relação interpessoal, ação terapêutica, intervenção, ideal moral ou como meio de promover a vida .

Para Boff (1999, p. 9), cuidar é mais que um ato, é uma atitude de ocupação, de preocupação, de responsabilizar-se pelo outro. Cita os enfermeiros em seus atos e atitudes que cuidam e adotam procedimentos para o cuidar.

Silva (1999, p. 256), de forma dialética, aborda que o cuidado deve ser considerado em sua dimensão mais global. Para tanto, chama a atenção dos cuidadores da enfermagem, ou seja, dos trabalhadores, no sentido de fortalecer a integridade de seu ser, o senso de coesão e participação. Nesta dimensão, rejeitando as crenças e valores que a organização dos serviços de saúde lhes impõe, o cuidador deve encontrar coragem para vencer a impotência, o imobilismo que se apresenta no cotidiano do cuidado, para agir de forma transformadora.

Este apontamento remete aos levantamentos de outra autora, Silva (1989, p. 135), que, ao abordar a enfermagem como profissão, realiza uma análise crítica, descrevendo que os traços principais que caracterizam a enfermagem, que denomina de tradicional e as transformações que nela operam, que é apreender sobre o embate de transformações mais gerais na esfera das relações de produção e das forças produtivas. Assim é que a existência da enfermagem tradicional 
coincide com o pré-capitalismo e a enfermagem moderna fundamentou-se no conhecimento científico e no ensino sistematizado, com a criação das Escolas de Enfermagem no Brasil nas décadas de 40 e 50, caracterizada pelo assalariamento e pela reprodução em seu interior da divisão do trabalho intelectual e manual, que é produto do capitalismo.

A lógica capitalista encontrou possibilidades na enfermagem brasileira que tem suas raízes no sentimento de religiosidade e marca seu espírito até os dias atuais. Em função disso, os trabalhadores de enfermagem enfrentam dificuldades de ordem profissional, com uma organização política frágil, com baixa remuneração (MUROFUSE, 2004).

O trabalho de enfermagem tem características de predominância do gênero feminino e está hierarquicamente dividido nas categorias de nível superior, pelo enfermeiro e de nível médio, por técnicos e auxiliares de enfermagem. A profissão é regulamentada e sua legislação especifica as categorias profissionais e descreve as atribuições de cada uma no exercício da profissão (OGUISSO; SCHMIDT, 1999, p. 18).

A enfermagem, cuja essência encontra-se no cuidado, teve no Brasil um marco para conformação enquanto profissão, na década de vinte, quando as enfermeiras norte-americanas implantaram o sistema nigthingeleano, com a criação de uma Escola de nível superior (MUROFUSE et al., 2005, p. 257).

Nessa perspectiva, é de fundamental importância que a enfermagem entenda seu trabalho como uma prática social, histórica, determinada e transformadora. Mediante esta compreensão, é que o homem apreende, 
compreende e transforma as circunstâncias, ao mesmo tempo em que é transformado por elas (MARX; ENGELS, 1999, p. 202 ). Assim, então, é possível a construção social da profissão.

Almeida e Rocha (1997, p. 23) afirmam que o processo de trabalho é o modo como o homem produz e reproduz sua existência. Ao fazê-lo, estabelece relações sociais e objetiva a sua subjetividade. As concepções históricas, materialistas e dialéticas procuram demonstrar que cada geração transmite uma massa de força produtiva, de capitais e de circunstâncias que é, por um lado, muito modificada pela nova geração, mas por outro, dita-lhe suas condições de existência e lhe imprimem um desenvolvimento determinado, um caráter específico. Conseqüentemente, as circunstâncias fazem os homens, da mesma forma que os homens fazem as circunstâncias.

Nogueira (1997, p. 72) considera, ao analisar o processo de trabalho em saúde, que este apresenta características comuns como os outros processos de trabalho em geral, ou seja, tem uma direcionalidade técnica que envolve instrumentos e força de trabalho; é um serviço, trabalho prestado a alguém. O processo de trabalho em saúde é entendido como uma dinâmica das transformações sociais determinadas pelas relações entre os seres humanos por meio de seus trabalhos.

O processo de trabalho em saúde pressupõe uma antevisão dos resultados esperados e uma ação para que aconteça, como qualquer trabalho humano. A sua direcionalidade técnica é fazer com que os instrumentos necessários para essa 
transformação atuem sobre o objeto, fundamentados pelos conhecimentos científicos (KALINOWSKI, 2004, p. 23).

Tradicionalmente, a enfermagem exerce suas atividades predominantemente na área hospitalar que oferta mais serviços. Porém, a partir dos anos oitenta, especialmente com o debate instituído na $8^{\mathrm{a}}$ Conferência Nacional de Saúde em 1986, surgiram maiores oportunidades para o trabalho de enfermagem em centros de saúde e ambulatórios.

De acordo com Schraiber; Nemes; Mendes (2000, p. 35), a Unidade Básica de Saúde é a célula básica, o estabelecimento da rede oficial que detém autoridade e responsabilidade legais para programar as atividades junto à comunidade, partindo de um diagnóstico de saúde. Ela atua em área determinada geograficamente, enfatiza as atividades de proteção e promoção da saúde da população, utiliza técnicas preventivas e curativas com tecnologia adequada. Neste sentido, apresenta caráter dinâmico, desenvolvendo as atividades em ação conjunta com a comunidade e equipe multiprofissional. A equipe de enfermagem neste contexto é o sustentáculo dos serviços e modelos assistenciais em saúde.

Kalinowski (2004, p. 18) pondera que a prática social da Enfermagem deve ser discutida e aprofundada cotidianamente com os profissionais atuantes em unidade de saúde para que possibilite o reconhecimento, a valorização e mudanças no trabalho da enfermeira - este voltado muito mais para as ações administrativas e gerenciais do serviço.

A enfermagem que sempre se interessa pela saúde do outro, ao executar seu contínuo trabalho de cuidar, abandona muitas vezes a necessidade de voltar-se 
para seu próprio autocuidado como pessoa e profissional de enfermagem. Executa seu trabalho em locais mal equipados, o que a expõe a riscos e agravos à sua saúde.

O trabalho é caracterizado por ambientes de trabalho insalubres, pela falta permanente de recursos humanos e de recursos materiais, pelo uso de tecnologia de procedimentos avançados, acompanhada de escassez de recursos para sua melhor adequação. Aliada a esta situação, há uma constante exigência de inovação e qualidade dos cuidados prestados, embora não acompanhado de uma adequada valorização de sua atuação.

Robazzi e Marziale (1999, p. 333) apontam que os profissionais de enfermagem estão sujeitos a trabalhar em condições geralmente penosas e desagradáveis pela necessidade de rodízios em escalas de plantões. Um trabalho ininterrupto, em turnos alternados, com realização de horas extras, muitas vezes em condições angustiantes, causando perturbações em seu ritmo biológico e em sua saúde. As autoras ressaltam os salários aviltantes, incompatíveis com a dignidade de suas atividades, obrigando muitas vezes os trabalhadores de enfermagem a terem duplo ou triplo emprego. Vêem-se repetidas vezes com os dilemas e dores alheias, com o sofrimento e com os demais problemas do setor de trabalho, demonstrando uma postura profissional controlada, em relação ao outro que recebe seus cuidados.

Estes fatos podem ser entendidos porque durante muitos anos a enfermagem foi considerada uma ocupação por vocação, sem preocupações com os ambientes laborais (BULHÕES, 1998). 
Stacciarini e Trócoli (2001, p. 17) destacam que alguns componentes são ameaçadores ao meio ocupacional do enfermeiro, entre eles o número reduzido de profissionais de enfermagem no atendimento em saúde em relação ao excesso de atividades que eles executam, as dificuldades em limitar os diferentes papéis entre as categorias de enfermagem e a falta de reconhecimento nítido entre o público em geral de quem é o enfermeiro.

Entre os estudos sobre o dimensionamento de pessoal de enfermagem é mister citar que estes privilegiam a área hospitalar. São pesquisas sobre dimensionamento de enfermagem em centro obstétrico (RICHTER et al, 1982), estudo das variáveis do dimensionamento de pessoal de enfermagem em hospitais de grande porte (MAGALHÃES et al, 1995), análise do dimensionamento na unidade de pós-operatório (PAVANI, 2000) e em pronto socorro (FARIAS, 2003)

Não existem estudos específicos de dimensionamento de pessoal de enfermagem em unidades básicas de saúde.

A enfermagem desenvolve ações de forma efetiva em UBS, compreendendo a atenção à saúde da criança, da mulher, do adulto, idoso e da comunidade através da consulta de enfermagem, planejamento, familiar, imunização e curativos.

Em relação à organização do trabalho, Almeida e Rocha (1997, p. 109), em seus estudos em UBS, relatam sobre o trabalho de enfermagem e sua articulação com o processo de trabalho em saúde coletiva. Assinalam que o trabalho das várias categorias profissionais não é articulado, as tarefas visam o imediatismo do atendimento. Neste sentido, apontam que a organização tecnológica deve ser 
refletida com a participação dos trabalhadores, pois a prática em saúde coletiva é social e outras ações devem ser implementadas.

No sentido de contribuir para esta questão, a Associação Brasileira de Enfermagem publicou em 1999, a classificação das práticas em saúde coletiva. Esse projeto configurou-se como uma estratégia técnica e política da ABEn para o desenvolvimento da enfermagem brasileira em saúde coletiva. Para tanto, três propósitos foram traçados e alcançados, os quais foram estabelecer mecanismos de cooperação para a classificação da prática de enfermagem em saúde coletiva no país, revisitar as práticas de enfermagem em saúde coletiva no país, contextualizadas no processo de produção em saúde, diante da implantação do Sistema Único de Saúde; e construir um sistema de informação das práticas de enfermagem em saúde coletiva que permita a sua classificação, troca de experiências e interlocução nos níveis nacional e internacional (ASSOCIAÇÃO BRASILEIRA DE ENFERMAGEM -ABEn, 1999).

Silva; Nozawa; Silva (2001, p. 989), em pesquisa realizada no município de Campinas do Estado de São Paulo, apontam as principais atividades desenvolvidas pelas enfermeiras na rede básica com as de treinamento e supervisão do pessoal de enfermagem; a assistência e as ações educativas e preventivas nas áreas da criança e adolescente, mulher, adulto e idoso; bem como as ações de vigilância epidemiológica e sanitária. Destacaram, ainda, as atividades agrupadas na "co-gerência", junto ao coordenador da unidade local de saúde que, na maioria das vezes, também é uma profissional enfermeira, tais como o planejamento das atividades do Centro de Saúde nas diferentes áreas de atenção; a 
organização de campanhas de vacinação e ações extramuros e intersetoriais, junto às escolas, creches, indústrias, empresas e demais instituições de sua área de abrangência.

Dentre as atividades assistenciais desenvolvidas nas unidades de saúde, preconiza-se que a enfermeira seja a coordenadora das ações assistenciais de saúde e administrativas inseridas nos programas ou projetos de saúde planejados nas unidades de saúde ou na comunidade sob a responsabilidade do serviço de saúde. Cabe à Enfermeira, também, ser a coordenadora das atividades assistenciais advindas da atividade médica, isto é, ser a executora, supervisora e avaliadora de procedimentos de enfermagem: curativos; administração de medicamentos; visita domiciliar; triagem, organização da demanda às consultas médicas, entre outras, que são na grande maioria realizadas pela equipe de auxiliares de enfermagem (KALINOWSKI, 2004, p. 19).

A divisão do trabalho da equipe aparece nas atividades e nas ações dentro e fora da unidade de saúde, o auxiliar de enfermagem é encarregado de um dos procedimentos por determinado período, estando a sua prática profissional sob supervisão, controle e responsabilidade da Enfermeira (KALINOWSKI, 2004, p. 19).

Estudos sobre trabalhadores em Unidades Básicas de Saúde são escassos e nenhum deles aborda a análise ergonômica. Silva e Felli (2002) realizaram um estudo comparativo sobre a identificação dos riscos ocupacionais por trabalhadores de enfermagem em duas unidades básicas de saúde. Nesta pesquisa, evidenciaram a exposição dos trabalhadores aos riscos biológicos, mecânicos, 
psíquicos, fisiológicos e químicos:

- biológicos: transmissão de patógenos por vias áreas, e/ou secreções de sangue por contato direto com o cliente;

- mecânicos: representados por acidentes com objetos perfuro-cortantes, quedas e agressão física;

- psíquico: estresse, pressão, insatisfação com a situação da saúde pública e situações angustiantes;

- fisiológicos: agravos à coluna vertebral, danos ósteo-musculo-articulares, caminhadas excessivas, execução de movimentos repetitivos e a presença de mobiliários inadequados;

- químicos: evidenciados pela exposição a medicações, vacinas e odores fortes.

Nascimento (2003), em sua dissertação, preocupou-se com o absenteísmo dos trabalhadores de enfermagem em uma unidade básica e distrital de saúde do município de Ribeirão Preto. Em seu estudo, evidenciou o absenteísmo como um problema gerencial correlacionado ao dimensionamento de pessoal.

Para Laurell e Noriega (1989), sob o referencial do materialismo histórico dialético, o trabalho de enfermagem deve ser analisado através das cargas de trabalho. Para os referidos autores, a situação de trabalho constitui uma integração entre o trabalhador e as características sócio-econômicas relativas ao processo de trabalho que gera processos de saúde-doença, o que implica na necessidade de explicitar como o social se traduz no biológico e como este se submete ao social. Para compreender o trabalho, como determinante do processo saúde-doença, é necessário analisar as formas históricas do capitalismo. Assim, a análise das 
intermediações do processo de trabalho e das cargas e desgaste permitem articular essa relação.

O trabalho é desenvolvido como um modo de produção capitalista, com a finalidade de gerar lucro e mais valia. Esse ocorre simultaneamente e somente pode materializar-se no momento concreto da produção de bens e serviços, ou seja, no processo de trabalho. No processo de trabalho, ocorrem as formas de adaptação, ou seja, a capacidade de o corpo responder com plasticidade diante das condições específicas de desenvolvimento que se expressam como formas biológicas características. Quando ocorrem as formas de adaptação destrutivas da integridade corporal, depreende-se que existem nos processos de trabalho elementos que interatuam entre si e com o corpo do trabalhador que se traduzem em desgaste, este relacionado às cargas de trabalho. As transformações negativas que se originam na interação com as cargas de trabalho geram a perda da capacidade efetiva e/ou potencial e psíquica, que é definida como desgaste (LAURELL; NORIEGA, 1989).

Distinguem-se dois tipos de cargas, as cargas de materialidade externa (independentes do corpo do trabalhador) representadas pelas biológicas, físicas, químicas e mecânicas; e as cargas de materialidade interna (identificadas através do corpo do trabalhador) que constituem as fisiológicas e psíquicas (LAURELL; NORIEGA, 1989).

Para Gonçalves (1994, p. 108), o trabalho em saúde como um serviço prestado desenvolveu-se no capitalismo com a finalidade de controlar as doenças e recuperar a força de trabalho incapacitada, isto pelo significado que os corpos 
humanos adquirem como força de trabalho. Castellanos (1989) ressalta que o trabalho de enfermagem insere-se no trabalho coletivo em saúde. Diante da mesma finalidade, transforma o corpo em objeto de trabalho, investido socialmente, e utiliza meios e instrumentos: saber, materiais, equipamentos e o local de trabalho, sob determinada organização e divisão.

No trabalho de enfermagem, esses indicadores não têm sido captados, tornando menos visível o processo de desgaste a que os profissionais têm sido submetidos. O desgaste deve ser considerado juntamente com os processos produtivos (LAURELL; NORIEGA, 1989).

Bulhões (1998, p. 15) considera, no referencial positivista, que a enfermagem executa suas atividades em condições de trabalho que expõe os profissionais a riscos ocupacionais diversificados.

Segundo Mattos (1997, p. 13), a origem do fator de risco, a extensão em relação a sua ação, o exercício da atividade e a lesão oferecem subsídios para classificar em relação aos agentes internos do trabalho:

riscos físicos: são os agentes que têm capacidade de modificar as características físicas do meio ambiente. A ação independe da pessoa estar exercendo sua atividade e do contato direto com a fonte; em geral, ocasionam lesões crônicas. riscos mecânicos : são os agentes cuja fonte tem ação em pontos específicos do ambiente. Sua ação independe da pessoa estar exercendo sua atividade e depende do contato direto com a fonte. Em geral, ocasionam lesões agudas. Como exemplo, as decorrentes de choque elétrico ou de tombos em piso escorregadio, 
dentre outros.

riscos químicos : são encontrados na forma sólida, líquida ou gasosa, cuja ação pode ocasionar tanto lesão crônica quanto aguda. Podem atuar em distintos estados e condições, isto é, sob a forma gasosa (sólidas e líquidas), diluídos no ar (gases ou vapores), suspensos no ar (poeiras e fumos) e na forma líquida (neblina e névoas) diluídos no ar e os suspensos são chamados de aerodispersóides.

riscos biológicos: são os seres vivos (micro ou macrorganismos), cuja ação pode provocar tanto lesão crônica quanto aguda. Exemplo: vírus, bacilos, parasitas, insetos transmissores de doenças (barbeiros, moscas, mosquitos), ratos, cobras.

riscos sociais: são ligados às relações de produção. Exemplo: treinamento, jornada, trabalho noturno, horas extras, revezamentos.

riscos ergonômicos: são os agentes cuja fonte tem ação em pontos específicos do ambiente. Sua ação depende de a pessoa estar exercendo a sua atividade e tem reflexos psicofisiológicos. Geralmente ocasionam lesões crônicas. Exemplo: ritmo, repetitividade, postura, dimensionamento e arranjo inadequado das estações e seções de trabalho.

Os riscos ergonômicos envolvem máquinas, mobiliários, posturas, adequação dos equipamentos e instrumentos, dimensões. Também geram estudos biomecânicos, de conforto ambiental, de posto de trabalho e organização laboral. Relacionam a hierarquia, a divisão do trabalho, a comunicação, a característica dos trabalhadores, o processo de trabalho e o estudo do desgaste humano em relação à alimentação, metabolismo, trabalho estático e dinâmico, cargas, confiabilidade e 
fadiga. Todos inseridos no ambiente profissional (MARZIALE, 1995; FARIAS, 1999). Assim, a análise ergonômica constitui-se um referencial teórico apropriado para estudar a situação de trabalho na enfermagem.

Bulhões (1998, p. 78) descreve que a análise da situação ergonômica de trabalho faz-se necessária para atentar-se aos aspectos que proporcionem conforto no desempenho das tarefas entre as quais a temperatura, o ruído, a umidade, a organização, desenvolvimento das tarefas, ritmo e modo como se desenvolve a atividade de enfermagem.

A Organização Internacional do Trabalho (OIT) e Organização Mundial da Saúde (OMS) vêm atuando ao longo dos anos, com o objetivo de garantir melhores condições de vida e trabalho e emprego aos trabalhadores, incluindo os integrantes da equipe de enfermagem.

Em 1977, durante a $62^{\mathrm{a}}$ Conferência da OIT, foram aprovados sob a forma de Convênio 149 e Recomendação 157 apontamentos versando sobre emprego e condições de trabalho e vida do pessoal de enfermagem. As questões relativas à saúde do trabalhador em geral foram retomadas pela OIT e, em 1985, na $71^{\text {a }}$ Reunião Internacional do Trabalho, foi discutida a realização do Convênio 161 e da Recomendação 171 acerca dos serviços de saúde do trabalhador (FARIAS; MAURO; ZEITOUNE, 2000, p. 31).

No Brasil, somente em maio de 1991 o convênio foi ratificado. O mesmo não ocorreu com o Convênio 149, que tratou especificamente do pessoal de enfermagem, suas condições de vida, trabalho e emprego. O Consejo Internacional de Enfermeras (CIE, 1986, p. 3) então destacou que as inquietações relacionadas 
com a saúde e a segurança no trabalho são cada vez mais expressivas e que, em muitos países, a maior responsabilidade para prover os serviços de saúde do trabalhador recai sobre o enfermeiro.

Em 1972, o Ministério do Trabalho (MTb), por meio do Plano Nacional de valorização do Trabalhador, homologou a Portaria MTb nº 3.236 criando assim o serviço de saúde ocupacional nas empresas, formado por engenheiro do trabalho, médico do trabalho e técnico de segurança do trabalho. Posteriormente, a Portaria MTb $n^{\circ} 3.237 / 72$ tornou obrigatórios nas empresas com mais de 100 empregados os serviços de saúde ocupacional, incluindo o auxiliar de enfermagem do trabalho na equipe de saúde ocupacional.

Cabe destacar que, em 1975 pela Portaria MTb n 3.260, o enfermeiro foi obrigatoriamente incluído na equipe de saúde ocupacional. A Portaria MTb $\mathrm{n}^{\circ}$ 3.214/78 e a Norma Regulamentadora $\mathrm{n}^{\mathrm{o}} 4$ do Ministério do Trabalho preconizam o dimensionamento de enfermeiros e auxiliares de enfermagem do trabalho para cada empresa, de acordo com o grau de riscos e o número de empregados de cada empresa (SCHMIDT, 1984, p. 91).

A enfermagem buscou avançar em sua especialidade de enfermagem do trabalho, criando cursos de especialização no país, encontros nacionais e, em 1986, dá-se a criação da Associação Nacional de Enfermeiros do Trabalho (ANENT), num esforço conjunto dos enfermeiros do trabalho de todo o país, visando o intercâmbio e união de ideais que estavam isolados nas ações e atuações destes profissionais.

No cenário de atuação da enfermagem do trabalho, insere-se a assistência 
aos trabalhadores, na promoção e proteção da saúde, na informação e educação em saúde, com a participação dos trabalhadores, a integralidade e interdisciplinaridade da prática em equipe em benefício da saúde do trabalhador.

A saúde do trabalhador teve seu conceito amplamente discutido por ocasião da realização da I Conferência Nacional sobre a Saúde dos Trabalhadores. Três pilares sustentaram significativamente este debate: o diagnóstico da situação de saúde e segurança dos trabalhadores, as novas alternativas de atenção à saúde dos trabalhadores e a política nacional de saúde e segurança dos trabalhadores.

A mudança no paradigma da saúde conduziu a mudança no conceito de saúde dos trabalhadores que, de acordo com o documento final da I Conferência Nacional de Saúde do Trabalhador em 1986, ultrapassa os aspectos biológicos e extrapola os limites da saúde ocupacional, apontando-a como resultante de um conjunto de fatores de ordem política, social, econômica, ou seja, traz novos significados. Este conceito inclui: condições dignas de trabalho, pleno emprego, trabalho estável e bem remunerado, oportunidade de lazer, organização livre, autônoma e representativa de classe, informação sobre todos os dados que digam respeito à relação saúde/vida/trabalho, acesso a serviços de saúde com capacidade de resolutividade em todos os níveis, efetiva participação em quaisquer decisões sobre assuntos referentes à classe, e direito de recusa ao trabalho sob condições reconhecidas de agressividade à saúde (ABRANCHES, 2000, p. 19).

Farias (1999, p.10) ressalta que a enfermagem deve refletir sobre suas questões de trabalho e saúde, com vistas à melhoria de suas condições de vida e de trabalho. Assim, evidenciam-se investimentos no desenvolvimento de mecanismos 
e estudos voltados para este objetivo, pois se acredita que a qualidade da assistência prestada tem relação direta proporcional às condições de trabalho que lhe são oferecidas.

Apesar dos avanços históricos da compreensão do mundo do trabalho da enfermagem, os profissionais ainda enfrentam desafios em seu processo de trabalho. 


\subsection{A violência no trabalho do setor de saúde}

A violência no Brasil configura, nos dias atuais, uma situação preocupante que atinge os indivíduos, as famílias, as comunidades, a população, ou seja, a sociedade como um todo. Ela se agrava continuamente, ganha magnitude e causa forte impacto sobre os dados de morbidade e mortalidade da população.

A violência é um evento representado por ações realizadas por indivíduos, grupos, classes, nações, que ocasiona danos físicos, emocionais, morais e espirituais a si próprio e a outros. Observa-se o aumento deste evento, refletido pela deterioração das condições de vida e de saúde, associado à precária atuação da rede de serviços de saúde (BRASIL, 2002).

A violência apresenta-se, nesta década, como fenômeno cujas facetas são objeto do cotidiano, pelo desencadeamento de temores aos assaltos, seqüestros e assassinatos. Ela também passa a ser objeto de reflexão por parte de várias áreas do saber, entre elas a saúde pública, pelo papel que assume diante da morbimortalidade, vitimizando crianças, jovens, adultos e idosos (MINAYO; SOUZA, 1993, p. 65).

Ela atinge a todos enquanto sujeitos e vítimas, sobretudo os trabalhadores, seja nas suas formas fatais, seja em manifestações tais como lesões físicas, psíquicas e simbólicas (ALMEIDA, 1988, p. 132).

Minayo (1994, p. 7) argumenta que trata-se de um complexo e dinâmico fenômeno biopsicossocial, mas seu espaço de criação e desenvolvimento é a vida 
em sociedade. Na configuração da violência, cruzam-se problemas da política, da economia, da moral, do direito, da psicologia, das relações humanas e institucionais, e do plano individual.

Num esforço de trazer o tema para a reflexão científica, a mesma autora apresenta uma classificação bastante geral, mas que permite, pelo menos, não reduzi-lo ao mundo da delinqüência, conforme abaixo:

\section{Violência Estrutural}

Entende-se como aquela do comportamento e se aplica tanto às estruturas organizadas e institucionalizadas da família como aos sistemas econômicos, culturais e políticos que conduzem à opressão de grupos, classes, nações e indivíduos, aos quais são negadas conquistas da sociedade, tornando-os mais vulneráveis que outros ao sofrimento e à morte.

\section{Violência de Resistência}

Constitui-se das diferentes formas de resposta dos grupos, classes, nações e indivíduos oprimidos à violência estrutural. Esta categoria de pensamento e ação geralmente não é "naturalizada"; pelo contrário, é objeto de contestação e repressão por parte dos detentores do poder político, econômico e/ou cultural.

\section{Violência da Delinqüência}

É aquela que se revela nas ações fora da lei socialmente reconhecida. A análise deste tipo de ação necessita passar pela compreensão da violência estrutural que 
não só confronta os indivíduos uns com os outros, mas também os corrompe e impulsiona ao delito.

Palacios (2003, p. 214), em estudo realizado na cidade do Rio de Janeiro sobre violência no trabalho no setor saúde, classifica a violência no trabalho em violência física e violência psicológica e define-as assim:

- violência física: uso da força física contra outra pessoa ou grupo que causa malefícios físico, sexual ou psicológico. Inclui soco, chute, tapa, punhalada/ esfaqueamento, tiro, empurrão, mordida, beliscão, dentre outros.

- violência psicológica: uso intencional de poder, incluindo ameaça de força física, contra outra pessoa ou grupo, que pode causar prejuízos para o desenvolvimento físico, mental, espiritual, moral ou sexual. Inclui agressão verbal, assédio moral, assédio sexual e ameaças.

Cezar (2005), estudando os problema da violência ocupacional em um serviço de urgência hospitalar da cidade de Londrina-Paraná, constatou que os trabalhadores da equipe de enfermagem (100\% dos enfermeiros, $88,9 \%$ dos técnicos e $88,2 \%$ dos auxiliares de enfermagem) mencionaram ter sido vítimas de atos de violência no trabalho, assim como $85,7 \%$ dos médicos. As violências sofridas pelos trabalhadores foram $95,2 \%$, na forma de agressão verbal, $33,3 \%$ por assédio moral e sexual.

Costa (2005) analisou as formas de violência operantes no mundo do trabalho de enfermagem em um serviço de emergência e urgência clínica de uma instituição hospitalar pública de Mato Grosso com 1200 trabalhadores, dos quais 
400 de enfermagem.

Seu estudo possibilitou constatar que a violência no contexto de trabalho de enfermagem em emergência e urgência clínica opera por duas vias: estrutural/institucional e comportamental/relacional que se explicitam em quatro tipos de violência: violência estrutural (manifesta na imposição de sobrecarga física e mental aos trabalhadores); violência repressiva (evidenciada na negação do direito de exercer com segurança as atividades assistenciais e a um ambiente de trabalho seguro); violência alienação (explicitada pela obstaculização aos trabalhadores de usufruir o prazer de uma realização profissional competente, eficaz e de ser valorizado socialmente junto aos usuários e a sociedade) e violência clássica (revelada nas agressões físicas e verbais de membros da equipe de saúde e de usuários). Estes quatro tipos de violência desencadeiam violências menores: práticas profissionais traumatizantes, omissões, negligências, imperícias, atendimento fragmentado, informações parciais ou negadas, indiferença ao sofrimento e a dor, baixa auto-estima, dentre outras.

As pequenas violências cotidianamente praticadas fortificam as grandes violências estruturais e comportamentais, numa circularidade viciosa que impõe o entendimento de seus modos operatórios necessários para os enfrentamentos, com a finalidade de romper o processo e favorecer a auto-realização profissional e humana dos trabalhadores de enfermagem e da saúde (COSTA, 2005).

Para Farias (2004, p.96), a enfermagem é uma das categorias mais atingidas na área da saúde pela violência no lugar de trabalho, sendo as vítimas mais prováveis, os estudantes, a equipe de enfermagem, a supervisora de enfermagem e o pessoal das 
ambulâncias. Em seu estudo sobre a qualidade de vida no trabalho em centro municipal de saúde, constatou que os profissionais da área de saúde sofrem freqüentemente agressões físicas praticadas por pacientes e intrusos nas unidades. Assim, o comportamento destrutivo em relação à outra pessoa no local de trabalho é um fenômeno relativamente recente, mas intolerável.

Iossi (2004, p. 110), em sua tese sobre o envolvimento dos profissionais de saúde do município de Guarulhos na assistência às crianças vítimas de violências domésticas, verifica que o olhar sobre a violência e a intervenção sobre este problema está intimamente ligado com a história de vida dos profissionais, sua experiência e compromisso. Outra questão ressaltada pelos sujeitos e identificada na literatura, em sua pesquisa, foi a falta de priorização na atenção primária neste assunto, pois a ênfase do atendimento de situações de violência está nos níveis secundário e terciário, pela falta de informação dos profissionais de saúde para atuarem frente a este problema.

Nas questões da violência no trabalho, os profissionais de saúde são as vítimas de diversos tipos de violência, mas também não são preparados para enfrentar este componente no trabalho, que gera tensão, estresse profissional e riscos, agressões e mortes no trabalho.

Santos Júnior e Dias (2004, p. 47) citam que, entre os locais de trabalho onde profissionais de saúde estão sendo mais freqüentemente vítimas da violência, destacam-se os que atendem urgências e emergências e os que atendem pacientes psiquiátricos.

Os mesmos autores ressaltam locais onde são prestados os chamados cuidados primários, ou seja, as Unidades Básicas, também não escapam da 
violência. Assim, apontam que se deve reconhecer que os episódios de violência no trabalho afetam não só as vítimas destes atos, mas também os colegas de trabalho, familiares e empregadores.

O Ministério da Saúde (MS), no ano de 2001, preocupado com esta situação, aprovou a Portaria $n^{\circ} 737$ MS/GM, que regulamenta a Política Nacional de Redução da Morbimortalidade por acidentes e violência. Esta estabelece diretrizes e responsabilidades institucionais, nas quais estão contempladas e valorizadas medidas para a promoção da saúde e prevenção destes eventos, com o estabelecimento de processos de articulação dos gestores e serviços de saúde locais, estaduais e nacionais, com diferentes segmentos sociais (BRASIL. MS, 2002).

Em 2002, o mesmo Órgão Governamental (BRASIL, 2002a) chama a atenção para os dados de morbidade por acidentes de violência em 1996, reconhecendo as dificuldades do sistema de informação do Sistema de Saúde Nacional, devido à subnotificação e a outros fatores. Foram registradas 679.511 internações por estas causas em hospitais ligados ao Sistema Único de Saúde (SUS). Nestas, houve a preponderância do sexo masculino, da faixa etária de 15 a 29 anos, indicando que estes eventos devem-se, sobretudo, aos acidentes de trabalho e do trânsito.

A Organização Internacional do Trabalho (OIT), atenta a estes fatos, publica no ano de 2002, um programa conjunto com a Organização Mundial de Saúde (OMS), Conselho Internacional de Enfermagem (CIE) e os Serviços Públicos Internacionais (ISP). Este programa reconhece e aborda a violência no 
trabalho e suas repercussões negativas na prestação de serviços de atenção à saúde e para a dignidade e saúde dos trabalhadores, em especial do setor de saúde.

Este programa aponta diretrizes que podem ser aplicadas em todos os serviços e para todos os trabalhadores do setor público e privado, bem como ser aplicado em todos os tipos de trabalhos formais ou informais (OIT, 2002).

Sobre a violência no local de trabalho, Cary e Naomi (2002) relatam estudos sobre a violência que sofrem as pessoas no local de trabalho. Estes assinalam que as conseqüências da violência no trabalho repercutem consideravelmente na eficácia dos serviços de saúde, sobretudo em países em desenvolvimento, como o Brasil.

Fazem-se necessários estudos e políticas que possam nortear ações para reduzir estas situações. Neste sentido, é importante ressaltar as intervenções propostas na Política Nacional de redução de acidentes e violência citadas anteriormente, bem como também considerar as apontadas pela OIT, no programa em conjunto, que aponta diretrizes para enfrentar e reconhecer a violência no trabalho, de forma a reduzi-la, que se apresenta a seguir:

1. Direitos e responsabilidades gerais dos administradores, empregadores, trabalhadores, órgãos profissionais, comunidade em geral, no sentido de se conhecer as raízes destas questões, considerar sua dimensão social e cultural e adotar intervenções eficazes de maneira sistemática de forma integrada e participativa;

2. Reconhecimento da violência no local de trabalho, dos riscos e vulnerabilidade real a que alguns setores e trabalhadores estão mais sujeitos, especificamente 
os de saúde;

3. Evolução dos riscos laborais, analisando as informações disponíveis de acidentes, absenteísmos e rotatividade de pessoal. Muitos profissionais, entre os quais os da enfermagem, trabalham à noite e em domicílios, trabalham em contato com o público, com equipamentos (medicamentos, equipos, seringas e outros), com pessoas necessitadas (transtornos psiquiátricos e abuso de drogas), trabalham em más condições — o que os tornam mais vulneráveis.

4. Intervenções no local de trabalho - medidas a serem adotadas:

\subsection{Condições Prévias:}

Desenvolver uma cultura no trabalho centrada nos aspectos humanos; Aumentar a sensibilização dos trabalhadores e da comunidade no local de trabalho, chamando a atenção para os prejuízos da violência;

\subsection{Intervenções nas organizações}

\subsection{Intervenções nos espaços}

\section{4 - Intervenções nas pessoas}

Observa-se nesta abordagem que a comunicação, a informação e estudos que possam contribuir são elementos fundamentais para se implantar e difundir os aspectos de segurança e saúde nos locais de trabalho, especialmente em situações de violência laboral.

As ações produzidas visando à prevenção precisam ser elaboradas incluindo as comunidades e suas instituições, os diversos setores públicos (educação, saúde e justiça), as empresas e os meios de comunicação de massa 
(OFFICE FOR SUBSTANCE ABUSE PREVENTION - OSAP, 1991). Posturas e habilidades de enfrentamento, alternativas de lazer podem ser categorias trabalhadas em ações de prevenção. Tais ações devem ser elaboradas levando-se em conta o contexto a que se destinam e questões fundamentais, como o grupo etário, gênero, características individuais, situação social, tipo de comunidade e participação em grupos específicos. Uma atitude de escuta, aberta às vivências dos grupos e apoiada no respeito e atenta às peculiaridades sócio-culturais são elementos muito importantes (MINAYO; DESLANDES, 1998, p. 42).

O esforço neste sentido deve ser conjunto, envolvendo ações individuais, institucionais, intersetoriais e interdisciplinares. $\mathrm{O}$ reconhecimento da violência laboral e seus determinantes podem compor ações neste campo que, de fato, promova a saúde dos trabalhadores e da população. 


\subsection{Abordagem ergonômica do trabalho}

As situações do cotidiano pessoal e profissional das pessoas revelam que a atividade produtiva dos homens necessita ser estudada, estabelecendo uma relação entre os aspectos humanos presentes nas atividades do trabalho e os demais componentes do sistema de produção (VIDAL, 2001a).

A ergonomia tem sido estudada e é entendida de maneiras diferentes. Por isto, alguns estudiosos a definem como disciplina e outros como especialidade. Como disciplina, aborda a compreensão das interações entre os seres humanos e outros elementos de um sistema; como especialidade, aplica princípios, teorias, dados e métodos, a projetos que visam otimizar o bem estar humano e a performance global dos sistemas (IEA, 2000).

Etimologicamente a palavra ergonomia é derivada do grego, ergo (trabalho) e nomos (leis), e empregada para denotar a ciência do trabalho. É uma disciplina inicialmente orientada aos sistemas e que modernamente se estende em todos os aspectos da atividade humana (VIDAL, 2001b).

Ressaltando sua evolução histórica, podem-se destacar os estudos de Frederick Taylor sobre a organização do trabalho e de Frank e Lilian Gilbreth sobre técnicas de análise de tempo e movimentos para análise das atividades de trabalho, considerados como iniciais do estudo do relacionamento entre trabalhadores e trabalho. A ergonomia leva em consideração as diferenças individuais dos trabalhadores e planeja o ambiente de trabalho flexível para acomodar a variabilidade, sem sacrificar a segurança ou a produtividade (SLUCHAK, 1992). 
Em seu sentido clássico, a Ergonomia buscou primeiramente entender os fatores humanos pertinentes ao projeto de instrumentos de trabalho, ferramentas e outros aspectos típicos da atividade humana em ambiente profissional. Mais adiante buscou entender, tabelar, organizar dados sobre os fatores humanos que deveriam ser considerados não apenas para os instrumentos, mas para os projetos de sistemas de trabalho. Atualmente, busca entender os determinantes de uma atividade de trabalho que incluem a organização do trabalho e os instrumentos, procedimentos e estratégias operatórias (VIDAL, 2001 a, p. 7) .

Guérin et al. (2002) apontam que a ergonomia centrada na análise da atividade passou a buscar o apoio de outras disciplinas: a lingüística, a antropologia, a fisiologia, a psicologia do trabalho, a sociologia, a epidemiologia, a demografia do trabalho, enriquecendo seu enfoque.

Importantes menções cabem serem feitas ao período que circundou a Revolução Industrial, que não pode ser limitada a avanços nos processos técnicos, mas a toda uma evolução das formas de divisão do trabalho e das formas de interação entre pessoas e equipamentos técnicos (VIDAL, 2001 a, p. 8).

No século XX, destaca-se, em 1900, Taylor e Gilberth que estudam a denominada "Organização Científica do Trabalho". Os esforços destes estudiosos estavam orientados para a obtenção de melhor rendimento do trabalhador em relação aos estudos do movimento e tempo das operações no trabalho. Higienistas e psicólogos realizaram diversas investigações sobre os efeitos das condições de trabalho sobre a saúde e rendimento dos trabalhadores (IBERMUTUAMUR, 2000, p. 90). 
Segundo nos relata Iida (1990), os cientistas que haviam participado desse esforço decidiram continuar a empreitada voltando-se para a produção civil, utilizando os métodos, técnicas e dados obtidos para a indústria. Numa precursora forma de extensão universitária, são formados laboratórios universitários para atender a demandas industriais com sucesso.

Os principais tratados de ergonomia foram produzidos nos anos 60 e teve como dominante a abordagem HFE. Os mais interessantes são Woodson e Conover, (USA, 1966) e Grandjean (Suiça, 1974), aqui lançado pela Editora Qualimark sob o título "Ergonomia". Uma compilação acessível destes livros está em Iida (1990).

No período do pós-guerra, surgiu uma outra vertente da ergonomia, ensejada pelas necessidades da reconstrução do parque industrial europeu dizimado. No bojo de um pacto social, o projeto de reconstrução abria uma janela para o estudo de condições de trabalho, tendo como emblema uma fábrica de automóveis que, dadas suas características peculiares, tornar-se-ia um modelo da nova política industrial francesa. Em 1966, destaca-se Alain Wisner já com o método da Análise Ergonômica do Trabalho (AET) (VIDAL, 2000, p. 10).

A ergonomia utiliza os conceitos de saúde, de anatomia, fisiologia, psicologia, lingüística, bem como da arquitetura, design, antropometria, biomecânica, toxicologia, desenho industrial e informática, para realizar estudos in loco das atividades do trabalho, o que lhe atribui um caráter interdisciplinar .

O conceito de intervenção ergonômica inicialmente desenvolvido pela escola francesa de Ergonomia (GUÉRIN et al., 2002) é hoje uma forma 
internacional de atuação do profissional que trabalha com a ergonomia. A efetividade da ergonomia consiste no fato de resultar em transformações positivas no ambiente de trabalho. Diferencia-se desta forma de estudos e análises de caráter apenas descritivo ou sem comprometimento de fato com as mudanças no trabalho, como a produção de laudos ou diagnósticos acadêmicos (VIDAL, 2001 a, p. 11).

Ela situa-se entre as disciplinas citadas, buscando elementos e conhecimentos que, à luz de seu estudo particular da atividade de trabalho, permitem enriquecer diagnósticos e esclarecer métodos de projetos (VIDAL, 2001a).

Neste sentido, LIMA (2001, p. 36) aponta que ela estuda a "atividade real de trabalho", com vistas a sua transformação. Sua tradição mais rica, a escola francesa, demarcou-se, das concepções que evidenciavam no trabalho, um campo onde seriam aplicados os conhecimentos na interface homem e trabalho. Em contraposição à idéia de ciência aplicada, abandonou progressivamente os laboratórios em busca de teorias e métodos de análise que pudessem apreender a atividade humana em situações reais do trabalho.

Ela difere de outras áreas do conhecimento pelo seu carater interdisciplinar e natureza aplicada (DUL; WEERDMEESTER, 1995, p. 14). O primeiro significa que a ergonomia apóia-se em diversas áreas do conhecimento humano e o caráter aplicado configura-se na adaptação do posto de trabalho e do ambiente às características e necessidades do trabalhador.

A ergonomia constitui objeto de legislação pertinente à saúde dos trabalhadores, sob a forma de Normas Regulamentadoras (NR), dentre as quais a 
NR-17 (Portaria Mtb n 3.751, de 23 de novembro de 1990 do Ministério do Trabalho) que trata especificamente como instrumento de controle das condições laborais. Seu principal objetivo é estabelecer parâmetros que permitam a adaptação das condições de trabalho às características psicofisiológicas dos trabalhadores, de modo a proporcionar um máximo de conforto, segurança e desempenho eficiente.

Segundo a referida norma, as condições de trabalho incluem aspectos relacionados ao levantamento, transporte e descarga de materiais, ao mobiliário, aos equipamentos, e às condições ambientais do posto de trabalho e à própria organização laboral. Os especialistas desta área, ergonomistas, surgiram a partir da obrigatoriedade e legislação.

Vidal (2001a, p. 11) argumenta que a característica da intervenção ergonômica é a construção de um projeto que vai viabilizar a mudança necessária, para que possa inserir os resultados da ergonomia nas organizações que as demandam e que recebem os seus resultados. Esta construção divide a intervenção e se realiza em distintas etapas: a instrução da demanda, a análise da atividade e dos riscos ergonômicos, a concepção de soluções ergonômicas e a implementação ergonômica.

A intervenção ergonômica surge a partir de uma demanda que pode ter diversas origens. Pode ser a constatação de que em um determinado setor há um número elevado de doenças ou acidentes (demanda de saúde) ou outros tipos de reclamações, que podem ser administrativas, dos trabalhadores ou dos órgãos que 
representam os trabalhadores (demanda social). A demanda deve ser estudada e direcionada à análise (BRASIL, MT, 2002, p. 16).

Para Vidal (2001c), a análise ergonômica do trabalho consiste em buscar uma síntese de esquemas que configura um conjunto estruturado de análises intercomplementares dos determinantes da atividade das pessoas em uma organização.

Marziale e Carvalho (1998) esclarecem que a atividade do trabalho é composta pela tarefa prescrita (formal), pela tarefa real (efetivamente realizada), pelos instrumentos utilizados para realização da tarefa e pelo posto de trabalho (onde a tarefa é executada).

A atividade de trabalho é a confluência entre os componentes pessoais, organizacionais e tecnológicos de um processo de trabalho, que se utiliza à análise de: situação de trabalho, conteúdo de tarefas, normas de produção, exigência de tempo, determinação do conteúdo de tempo, ritmo de trabalho, carga de trabalho, trabalho prescrito e real e modo operatório das atividades executadas (VIDAL, 2001 b).

A tarefa é entendida como um conjunto de fenômenos fisiológicos e psicológicos específicos do homem, na realização de seus atos, onde eles investem seu corpo, seus pensamentos, desejos e esperanças, bem como sua história. A realização da tarefa prescrita refere-se ao trabalho prescrito, correspondendo ao conjunto de objetivos e prescrições apresentados aos trabalhadores, definidos pela gerência para atender os objetivos pela instituição (MARZIALE, 1995).

Segundo Marziale (1995), a análise das condições ergonômicas do trabalho 
deve conter elementos do ambiente de trabalho, do trabalhador, da atividade do trabalho e informações sobre os componentes secundários à situação de trabalho, tais como: os meios de transporte, a alimentação, a moradia, lazer e outros por serem imprescindíveis à saúde dos trabalhadores.

De outra forma, Wisner (1994) ressalta as razões para realizações de análises ergonômicas do trabalho, apontando que todas as atividades devem ser observadas, através de observações diretas e tomadas informações dos trabalhadores, pois certos aspectos significativos da tarefa estão prescritos e inscritos nos ensinamentos próprios da formação profissional; outros há que estão previstos e estão sujeitos à descoberta do trabalhador.

Seguindo os apontamentos e caminhos percorridos por Marziale $(1995,2000)$, o recorte conceitual a ser adotado tem como pressuposto teórico três componentes básicos da situação de trabalho que são o homem, a atividade e o ambiente de trabalho. A atividade de trabalho é composta pela tarefa prescrita, pela tarefa real, pelos instrumentos e pelo posto de trabalho.

Para análise do homem, como componente central da situação de trabalho, fatores como a educação, o treinamento, a motivação, a satisfação, a antropometria e o uso de equipamento de proteção individual são variáveis a serem consideradas.

Os trabalhadores apresentam diferenças individuais, a saber: estatura, peso, compleição física, resistência à fadiga, capacidade auditiva e visual, memória, habilidade motora, personalidade, entre outras, as quais podem atingir níveis significativos, por isto devem ser consideradas (IIDA, 1990)

A atividade de trabalho significa o trabalho real, efetivamente realizado 
pelo indivíduo, a forma pela qual ele consegue realizar suas tarefas. É resultado das definições impostas pela instituição com relação a sua tarefa e das características pessoais, experiências e treinamento do trabalhador (ABRAHÃO, 1993).

Marziale (1995, p. 24) destaca que, quanto ao instrumento de trabalho, são considerados como fatores o peso, a força, a posição, o modo e condições de manuseio.

O ambiente de trabalho compreende o conjunto de fatores interdependentes que atuam direta e indiretamente na qualidade de vida das pessoas e nos resultados do próprio trabalho. Esta visão global das influências do trabalho facilita a compreensão das dificuldades e desconfortos, da insatisfação, dos baixos desempenhos, das doenças e da ocorrência de acidentes de trabalho (IIDA, 1990).

Uma abordagem da análise das condições ergonômicas de trabalho deve conter, além dos componentes anteriores descritos, informações sobre os componentes secundários à situação de trabalho como o meio de transporte, moradia, alimentação, por serem imprescindíveis à saúde dos trabalhadores, ou seja, contemplar os aspectos psicossociais do trabalho e da vida dos trabalhadores, possibilitando uma visão mais ampla da situação de trabalho (MARZIALE, 2000, p. 25).

A reunião destes componentes e requisitos é essencial na aplicabilidade da ergonomia e o alcance de seu objeto maior, que é o de promover o bem estar, conforto e qualidade de vida e de trabalho aos trabalhadores, envolvidos nas 
contingências e interfaces do trabalho.

Laville (1977, p. 98) ressalta que a participação dos trabalhadores engajados neste processo é fundamental para situar a importância sentida de cada um dos problemas e contribuir para a interpretação dos fatos observados.

Iida (1990, p. 7) cita a classificação da ergonomia, destacando a sua contribuição, como ergonomia de concepção (quando a contribuição da ergonomia se faz na fase inicial do projeto do ambiente ou equipamento), ergonomia de correção ( quando é aplicada em situações reais, já existentes, para solução de problemas que se refletem na segurança e fadiga e em doenças do trabalhador) e a ergonomia de conscientização (quando, de forma individual e coletiva, proporciona aos trabalhadores a conscientização para trabalhar de forma segura, reconhecendo os riscos para evitá-los).

Nesta última década, a ergonomia tem sido mais divulgada no Brasil, embora continue desconhecida pela maioria das pessoas e pelos trabalhadores. Foram criados no Brasil vários cursos de pós-graduação lato-sensu, tornando a ergonomia uma área de especialização, bem como cursos de atualização e aperfeiçoamento, o que favoreceu seu crescimento, especialmente a atuação do especialista em consultorias, comissões e estudos do trabalho e das pessoas envolvidas nos mesmos.

Em relação às pesquisas em ergonomia, Vidal e Setti (2001, p. 21) realizaram um levantamento através da consulta ao Diretório dos Grupos de Pesquisa no Brasil. A Universidade Federal de Santa Catarina aparece em primeiro 
lugar (40,83\%), seguida pela Universidade Feral do Rio Grande do Sul $(17,38 \%)$ em número de pesquisadores, seguido pela Universidade Federal de Minas Gerais (UFMG), Universidade Federal do Rio de Janeiro (UFRJ) e Universidade de São Paulo (USP), sendo que na UFMG o grupo de pesquisa tem características interdisciplinares e se insere na Sociologia enquanto área de conhecimento. A UFRJ aparece como a principal formadora em pós-graduação. Na USP, destacouse Maria Helena Palucci Marziale nos grupos de pesquisa formados, especialmente na assistência de enfermagem.

Dentre as pesquisas realizadas com utilização da abordagem ergonômica na enfermagem, citam-se os estudos de Alexandre (1998 a) que abordam a ergonomia e as atividades ocupacionais da equipe de enfermagem e, ainda, os aspectos ergonômicos relacionados com o ambiente e equipamentos hospitalares (ALEXANDRE,1998 b), bem como publica uma proposta educativa com enfoque ergonômico para auxiliar na prevenção de lesões músculo-esqueléticas na equipe de enfermagem (ALEXANDRE,1998 c) . Marziale (1990) ressalta a relação da fadiga mental e o esquema de turnos alternantes e Marziale (1995) analisa a situação ergonômica do trabalho de enfermagem em uma unidade de internação de cardiologia. Royas e Marziale (2001) enfocam a situação do trabalho de enfermagem em um hospital argentino. Apud e Meyer (2003) abordam a importância da ergonomia para os profissionais de saúde no Chile. Mauro e Cupello (2001) estudam o trabalho de enfermagem hospitalar sob a visão ergonômica. Já Mauro (1976) e Mauro e Cupello (2001) verificam a fadiga e aspectos ergonômicos do trabalho de enfermagem. 
As transformações no trabalho, conseqüentes dos avanços tecnológicos, fazem emergir um novo olhar para analisar a relação do homem com o trabalho, ou seja, o homem inserido no contexto de trabalho, refletindo assim a necessidade de incorporar a esta análise, o ambiente no qual ocorre a atividade e que a condiciona e as conseqüências deste para o indivíduo e para a produção.

Ergonomistas, em sua prática profissional, devem ter uma compreensão abrangente da amplitude de seu papel, que é de promover uma abordagem holística do trabalho, na qual considerações de origem física, cognitiva, social, organizacional, ambiental e outros aspectos relevantes devam ser considerados. Assim, o Conselho Científico da IEA (2000) estabeleceu os domínios da área:

- Ergonomia Física - aplica-se às características da anatomia humana, antropometria, fisiologia e biomecânica em relação à atividade física. Os tópicos relevantes incluem a postura laboral, manuseio de materiais, movimentos repetitivos, distúrbios músculo-esqueléticos em relação ao trabalho, projeto de postos de trabalho, segurança e saúde.

- Ergonomia Cognitiva - relaciona-se aos processos mentais, tais como percepção, memória, raciocínio e resposta motora, conforme afetam interações entre seres humanos e outros elementos de um sistema. Os tópicos relevantes incluem carga mental de trabalho, tomada de decisão, interação homemcomputador, estresse e treinamento conforme estes se relacionam aos projetos envolvendo seres humanos e sistemas.

- Ergonomia Organizacional - refere-se à otimização dos sistemas 
sociotécnicos, incluindo suas estruturas organizacionais, políticas e processos. Os tópicos relevantes incluem comunicações, gerenciamento de recursos, projeto de trabalho, organização temporal, trabalho em grupo, projeto participativo, ergonomia comunitária e trabalho cooperativo, novos paradigmas do trabalho, cultura organizacional, organizações em rede, teletrabalho e gestão da qualidade.

Vidal e Setti (2001, p. 16) abordam que a ergonomia busca apresentar como resultados projetos com implicação em arranjos físicos, arranjos cognitivos e arranjo organizacional, que estão implicados na manutenção e gestão do trabalho.

Partindo do pressuposto de que a situação de trabalho exerce conseqüências ao desempenho, à satisfação e principalmente à saúde dos profissionais, acreditase que a ergonomia, com base em seus princípios e metodologia próprios, poderá acrescentar novos fatos e evidências que detalharão o trabalho de enfermagem, a fim de averiguar as reais influências das condições de trabalho nos locais onde a enfermagem atua, em sua saúde e vida.

Ela busca dois objetivos fundamentais: de um lado, produzir conhecimento sobre trabalho, as condições e a relação do homem com o trabalho; por outro, formular conhecimentos, ferramentas e princípios suscetíveis de orientar racionalmente a ação de transformação das condições de trabalho, tendo como perspectiva melhorar a relação homem-trabalho. A produção do conhecimento e a racionalização da ação constituem, portanto, o eixo principal da pesquisa ergonômica (ABRAHÃO; PINHO, 1999, p. 229). 
Esses conhecimentos, quando confrontados e articulados de forma integrada, contribuem com a tecnologia e a organização do trabalho na definição da melhoria desta realidade. Um dos interesses da Ergonomia é saber o que os trabalhadores realmente fazem, como fazem, por que fazem e se podem fazer melhor. Para tanto, ela tem como objeto específico de estudo a atividade real dos trabalhadores. (ABRAHAO; PINHO, 2002, p. 46).

Portanto estudos ergonômicos são recomendáveis e requerem uma análise ampla e uma metodologia apropriada. 


\section{Método}

\subsection{Tipo de estudo}

O estudo foi de abordagem ergonômica. Baseia-se nos conceitos de ergonomia propostos por Iida (1990) e instrumentos de análise ergonômica adaptados de Marziale (1995)

\subsection{Cenário}

Realizou-se em uma Unidade Básica de Saúde da Secretaria de Saúde do município de Volta Redonda do Estado do Rio de Janeiro.

No mês de agosto de 2003, foi realizado um primeiro contato com o setor de Recursos Humanos da Secretaria de Saúde do município de Volta Redonda/RJ, especificamente com a sua coordenação. Esta relatou que os trabalhadores de enfermagem estavam altamente adoecidos, pois não havia reposição de profissionais de nível médio há sete anos, pela falta de concursos públicos, o que lhes causava grande sobrecarga de trabalho. Relatou também que havia altas taxas de licenças médicas e absenteísmo, destacando o Distrito Sanitário IV como o que apresentava a maior evidência desta situação.

Foi encaminhada a solicitação de autorização para execução da investigação. Permitida a realização da investigação e após o contato inicial descrito, realizou-se, em fevereiro de 2004, um diálogo com a gerente do Distrito Sanitário IV. Esta visou conhecer os aspectos relativos ao seu organograma e os dados estatísticos dos absenteísmos nos anos de 2004 e 2005. 
O Distrito é composto por nove UBS. Foi selecionada uma UBS a ser investigada, tendo como critério de seleção a que apresentou a maior taxa de absenteísmos-doenças. A Unidade foi denominada UBS para efeito das análises e garantia do anonimato.

\subsection{Sujeitos do estudo}

O quadro funcional da UBS selecionada era composto por 16 trabalhadores, sendo 6 médicos, 1 enfermeiro (gerente da UBS), 1 técnico de enfermagem e 4 auxiliares de enfermagem, 3 recepcionistas e uma funcionária do serviço de limpeza. Participaram do estudo a gerente da UBS e quatro trabalhadoras de enfermagem, tendo como critério de seleção as que estavam presentes no momento da coleta de dados. Durante a coleta, uma das auxiliares de enfermagem encontrava-se em licença.

\subsection{Coleta de Dados}

\section{Primeira Fase:}

Constou da determinação de problemas relacionados à Ergonomia dentre as unidades de saúde do município de Volta Redonda do interior do Estado do Rio de Janeiro, visando estabelecer um pré-diagnóstico das condições de trabalho do pessoal de enfermagem, realizado através da identificação da demanda de saúde para a investigação.

Este primeiro momento, executado sob os princípios da abordagem ergonômica, foi o estabelecimento da necessidade da análise ergonômica. De 
acordo com o Ministério do Trabalho (BRASIL, MT, 2002), a análise começa por uma demanda que pode ser da constatação de que em determinado setor há um número elevado de doenças e acidentes (demanda de saúde).

Foi apresentado à pesquisadora o levantamento estatístico das notificações de licenças e afastamentos do trabalho dos profissionais de enfermagem das UBS, nos anos de 2003 e 2004. Evidenciou-se, assim, a demanda de análise ergonômica, pois foi constatada uma elevada taxa de licenças e afastamentos nestes anos. Selecionou-se, então, uma UBS - a que apresentou o maior índice de afastamentos.

\section{Segunda Fase:}

Foi caracterizada pela coleta na UBS que começou no mês de maio de 2005, com a realização das entrevistas à gerente e às trabalhadoras, pela própria pesquisadora. Todas as entrevistas foram feitas na sala da gerente da unidade, no horário da tarde, por ser considerado o que tem o menor fluxo de atendimento, assim favorecendo o contato da pesquisadora com os entrevistados.

A gerente da UBS foi a primeira entrevistada, durante duas horas, dentro da UBS, após o consentimento livre e esclarecido da mesma.

Nos dias seguintes, foram feitas as entrevistas com a equipe de enfermagem. Inicialmente, foi esclarecido sobre a pesquisa e todas as que participaram assinaram o termo de consentimento. As entrevistas individuais tiveram uma duração média de três horas. Durante alguns momentos eram interrompidas, pois as técnicas e auxiliares de enfermagem eram chamadas para resolverem situações da assistência aos usuários da UBS. A pesquisadora 
aguardava o retorno, respeitando esta necessidade.

Nas semanas seguintes, foi aplicada a técnica de observação. Inicialmente, nos postos de trabalho da equipe de enfermagem pela pesquisadora. Os postos de trabalho onde a equipe de enfermagem executava suas atividades na UBS compreendiam a sala de vacinação, sala de nebulização, sala de curativos, consultório de pré-natal e ginecologia, farmácia e sala de preparo e esterilização de material.

Os mobiliários das salas foram mensurados e fotografados. Para aferição das dimensões dos espaços, superfícies e mobiliários dos postos de trabalho foi usada uma trena $3 \mathrm{~m} / 10$ LUFRIN.

Também foram aferidos os agentes físicos do ambiente: temperatura, iluminação e ruído dos postos de trabalho. Nesta fase, a pesquisadora contou com a presença de um engenheiro de segurança do trabalho, na UBS, que emitiu as medidas posteriormente. A pesquisadora o acompanhou em todos os postos de trabalho, durante duas tardes na UBS.

As aferições de temperatura, iluminação e ruído foram efetuadas em 13 de maio de 2005 , no horário compreendido entre $13 \mathrm{~h}$ às $17 \mathrm{~h}$.

Em relação à iluminação, os valores médios foram aferidos em todas as salas com e sem luz artificial. Quanto ao ruído, sua aferição deu-se dentro das salas com a porta fechada e com a porta aberta.

A seguir, a pesquisadora observou a atividade de vacinação, desenvolvida por uma técnica de enfermagem. Foi selecionada a atividade de vacinação pela equipe de enfermagem entrevistada, tendo como critério de seleção a atividade em que a enfermagem mais atua e por ser específica da categoria profissional. 
Atividade de trabalho: forma pela qual o trabalhador de enfermagem desempenha as tarefas que lhes foram prescritas pela UBS, para qual houve a identificação dos seguintes elementos: as tarefas prescritas e as atividades efetivamente realizadas.

Para a mensuração do tempo gasto na atividade de trabalho executado e indicado pelos trabalhadores de enfermagem, foi utilizado pela pesquisadora um cronômetro ILONA.

\section{Terceira Fase:}

Compreendeu a fase do diagnóstico ergonômico, visando o planejamento de intervenções ergonômicas, com sugestões e recomendações para minimizar os problemas detectados nas fases anteriores.

\section{Quarta Fase:}

Correspondeu à fase de implementação das ações, a serem realizadas através de orientações. Foram formuladas estratégias ergonômicas, visando à melhoria das condições ergonômicas diagnosticadas, baseadas em argumentações e ações ergonômicas.

\subsection{Instrumentos de Coleta de Dados}

Para cada técnica de coleta de dados, foram utilizados os seguintes instrumentos de coleta de dados na UBS selecionada, a saber:

\section{Entrevistas:}

1) roteiro de entrevista com a gerente do serviço de enfermagem (Apêndice B): levantaram-se dados sobre as atividades da equipe de enfermagem, treinamentos, condições de saúde e violência laboral. 
2) roteiro de entrevista com os profissionais de enfermagem nas UBS (Apêndice C) : caracterizou-se o perfil dos profissionais de enfermagem atuantes na UBS selecionada para o estudo, verificando as seguintes variáveis da situação de trabalho: dados biográficos, dados antropométricos, nível de formação, experiência profissional, salários e benefícios, qualidade de vida, condição de saúde, violência laboral e impressões frente às condições de trabalho

\section{Observação:}

3) protocolo de observação e aferição dos agentes no ambiente físico de trabalho (Apêndice D).

Para o levantamento dos parâmetros de temperatura, utilizou-se um conjunto de termômetro de bulbo úmido natural (tbn), termômetro de globo (tg) e termômetro de bulbo seco (tbs), marca Politeste, modelo TGM100, digital, $\mathrm{n}^{\mathrm{o}}$ de identificação 19284, de acordo com as especificações do anexo no 3 da NR-15. Estes parâmetros foram tratados, segundo a equação $\mathrm{IBUTG}=0,7 \mathrm{tbn}+0,3 \mathrm{tg}$, para obtenção do "Índice de Bulbo Úmido - Termômetro de globo - IBUTG", para ambientes internos sem carga solar.

A intensidade dos níveis de iluminação foi medida utilizando-se um termohigro-anemometro-luximetro, marca Instrutherm, modelo THAL-300, digital, $\mathrm{n}^{\circ}$ de serie 04031800013163 com certificado de calibração.

Para a mensuração do ruído, foi utilizado um medidor de nível de pressão sonora, audiodosímetro (marca TES, modelo digital 1355, tipo 2, classificação 
ANSI SI 4 de 1983, n. ${ }^{\circ}$ de série 000809083), de procedência americana, devidamente calibrado, operando no circuito de compensação (A) e resposta slow, na escala de 40 a 140 decibéis, com certificação.

4) roteiro de observação dos postos de trabalho (Apêndice E);

5) folha de registro da atividade de trabalho com a técnica de observação sistematizada (Apêndice F);

A partir da entrevista realizada com a gerente da UBS, foi possível identificar o trabalho prescrito para a enfermagem. Este levantamento deu-se por meio de análise dos registros das rotinas formalizadas para a execução das práticas de enfermagem (Apêndice H) com a observação da atividade executada.

Através da técnica de observação intervalar (MARZIALE, 1995, p. 88), foram observadas as atividades executadas pela equipe de auxiliares e técnico de enfermagem. A atividade observada foi de vacinação, apontada pela equipe como a que exige maior nível de concentração e atenção.

Em ergonomia, as formas de descrição das situações de trabalho são baseadas na representação das características observáveis da atividade do trabalho. Esta descrição pode ser apresentada de forma estatística, por meio de cronologias e narrativas. As estatísticas mais freqüentemente empregadas são as ocorrências, as durações e os seqüenciamentos. As ocorrências consistem na contagem de quando e quando ocorrem determinadas passagens escolhidas previamente. As cronologias devem ser feitas quando se possa claramente delimitar início e fim da observação e, desta forma, articular observáveis elementares com o tempo (VIDAL, 2001 a, p. $14)$. 
A observação foi realizada durante 300 minutos em dois dias à tarde, período considerado pela equipe de enfermagem de maior fluxo de atendimento em vacinação, entre os quais o da terça-feira à tarde com a execução da vacina BCG (indicada para à prevenção da tuberculose) e a vacina contra hepatite B, conforme esquema básico. Neste estudo, usou-se a estatística e a cronologia por permitirem uma análise mais profunda da atividade, a partir da observação. Durante a observação, puderam ser constatadas especificidades da atividade. O número de atendimentos e as posturas adotadas pelos profissionais foram verificados.

No segundo dia, as posturas adotadas (em 180 minutos de atividades) foram observadas nas posições em pé, deambulando, sentado e dorso inclinado.

Todos esses instrumentos foram construídos e adaptados dos utilizados por MARZIALE (1995). Os instrumentos foram validados por três especialistas em ergonomia. Em todas as fases do processo de coleta de dados, foi utilizada a técnica de conversa-ação, considerada como princípio fundamental para análise ergonômica (VIDAL, 2001 c). Esta técnica preconiza a participação efetiva dos trabalhadores e um diálogo permanente com os mesmos durante a coleta de dados. Os preceitos éticos da Resolução no 196/96 (ANEXO A, B e APÊNDICE A) sobre pesquisa envolvendo seres humanos foram respeitados e aplicados. O projeto foi aprovado pelo Comitê de Ética em Pesquisa da Escola de Enfermagem de Ribeirão Preto - USP (ANEXO C).

\subsection{Análise dos resultados}

Os resultados foram analisados por meio de estatística descritiva e 
apresentados em quadros e figuras. Os dados foram compilados e discutidos, visando o alcance dos objetivos propostos. 


\section{Análise e discussão dos resultados}

A identificação da demanda de análise ergonômica foi constatada pelo relato inicial da gerente do Distrito de que os profissionais de enfermagem estão trabalhando adoecidos, sobrecarregados pelas demandas e solicitações da SMS, da própria unidade de saúde onde atuam e dos clientes, que exigem atenção e solução de seus problemas. Ela preocupa-se e realiza às vezes alguns encontros no Distrito de forma que os enfermeiros gerentes possam externar seus sentimentos, visando um pouco de alívio.

Para a análise ergonômica do trabalho de enfermagem, foi necessário conhecer o perfil dos trabalhadores de enfermagem, o processo de trabalho em saúde coletiva e identificar os determinantes dos problemas enfrentados no trabalho em UBS.

Dessa forma, o presente capítulo está assim estruturado: 5.1. Condições de vida e trabalho em enfermagem na UBS; 5.2. Os trabalhadores de enfermagem e os fatores determinantes das condições de trabalho; 5.3. Os postos de trabalho; 5.5 O ambiente e os agentes físicos 5.6. A atividade do trabalho e os fatores ergonômicos associados.

Buscou-se evidenciar, neste capítulo, a situação de trabalho da equipe de enfermagem que atuava na UBS, enfatizando os elementos que permitiram o conhecimento das especificidades da unidade para, posteriormente, apresentar as recomendações de intervenção ergonômica do trabalho. 


\subsection{Condições de vida e trabalho em enfermagem na UBS}

Apresenta-se inicialmente a estrutura organizacional da SMS e do Distrito

Sanitário. Estes dados foram obtidos por meio da gerente do Distrito Sanitário.

HSJB - Hospital São

João Batista

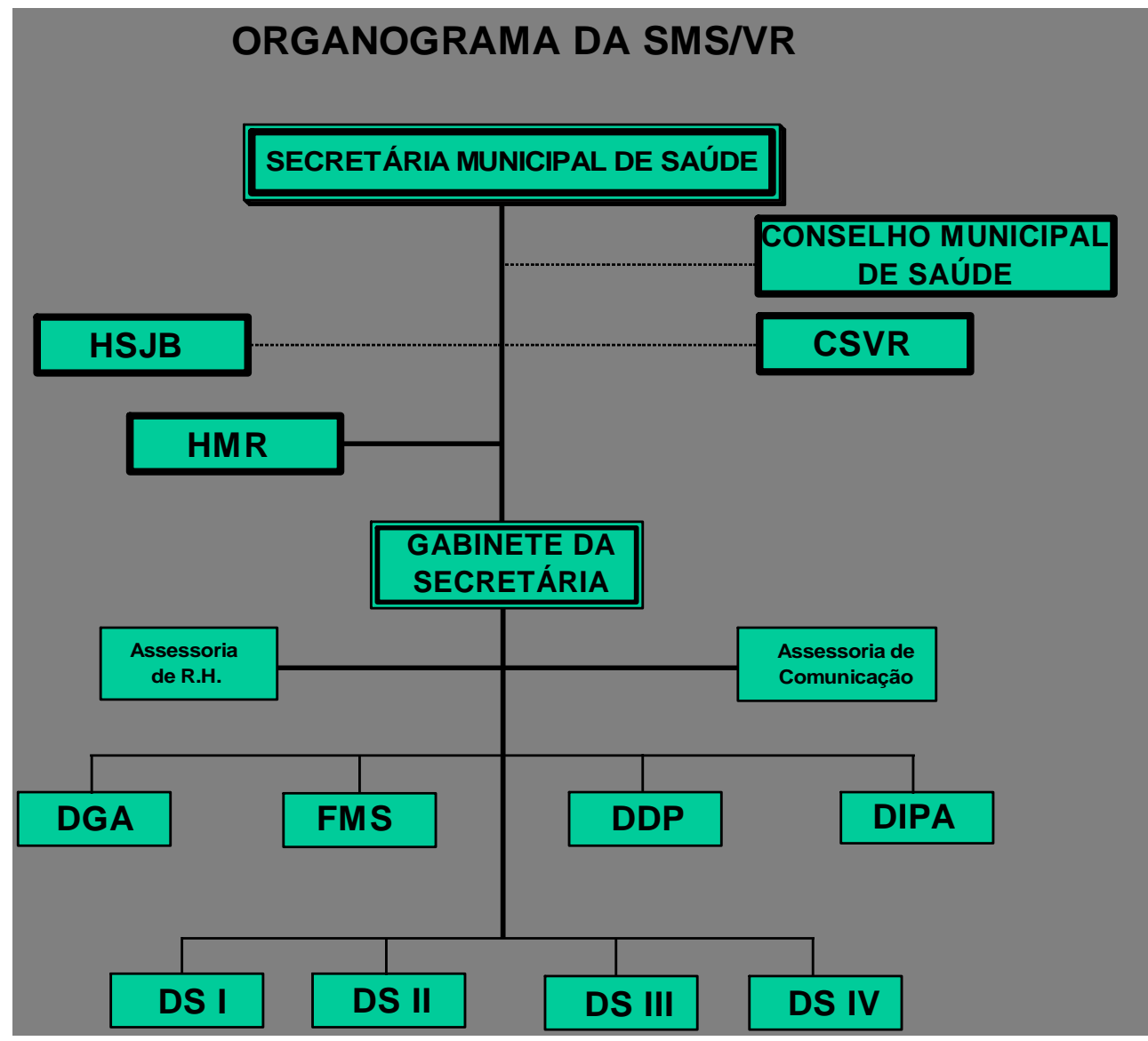

CSVR - Casa de

Saúde Volta

Redonda

HMR - Hospital

Municipal do Retiro

DGA -

Departamento Geral

de Administração

FMS - Fundo

Municipal de Saúde

DDP - Departamento de Desenvolvimento

de Programa

DIPA Departamento de Informação, Programação e

Avaliação

DS - Distrito

Sanitário

Figura 1- Organograma da SMS/VR

Fonte: Secretaria de Saúde do Município de Volta Redonda. Distrito Sanitário IV.

Volta Redonda, maio 2005. 
A estrutura organizacional do Distrito Sanitário IV é apresentada a seguir.

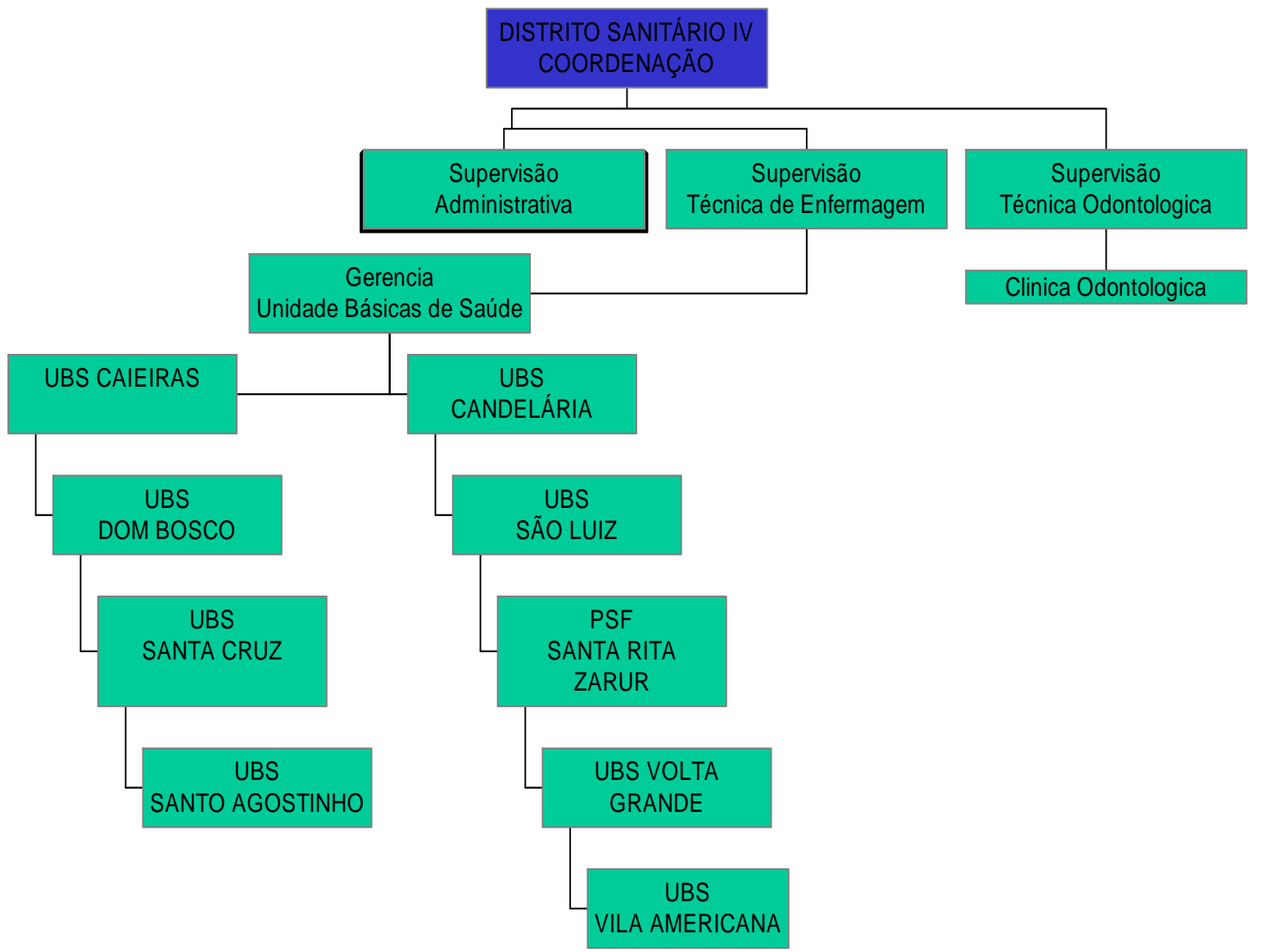

Figura 2- Organograma do Distrito Sanitário IV

Fonte: Secretaria de Saúde do Município de Volta Redonda. Distrito Sanitário IV.

Volta Redonda, maio 2005.

O sistema de saúde do município está organizado em uma rede de serviços, representada por dois hospitais, uma casa de saúde que se destina ao atendimento em saúde mental, três departamentos responsáveis pela administração, desenvolvimento de programas de saúde, informação, programação e avaliação, 
um conselho municipal de saúde, um fundo municipal de saúde e por quatro distritos sanitários. A atenção primária em saúde está sob a gerência dos distritos sanitários que têm como base o território, abrangendo um espaço demarcado pela aproximação administrativa de áreas geográficas dos bairros residenciais da população.

Os municípios podem organizar seus serviços de saúde pelo princípio da base territorial. O estabelecimento da base territorial é fundamental para a administração dos serviços locais de saúde, pois ele caracteriza a população e os seus problemas de saúde, viabilizando o processo de programação local e cria vínculos de responsabilidade das unidades para com a população. A base territorial é um espaço em permanente construção, pois este é produto de uma constante dinâmica social (FERREIRA, 2004, p. 75).

O mesmo autor aborda que, para a prática de reorganização de serviços de saúde, devem ser identificadas e analisadas as diferentes práticas de saúde, os elementos do processo de trabalho (objetos, meios e trabalho) inerentes a cada uma delas visando à reorganização dessas práticas nas Unidades de Saúde.

Verificou-se que no município o processo de descentralização, preconizado para consolidação do SUS, está pautado na estrutura organizacional que privilegia o território, denominado distrito sanitário.

O distrito sanitário como processo, segundo Mendes (1995, p. 166), é um território como um espaço em permanente construção, produto de uma dinâmica social em que se tencionam os sujeitos sociais desta área. Uma vez que essas tensões são permanentes, o território nunca está acabado, mas, ao contrário, em 
constante construção e reconstrução. Segue a lógica político-administrativa do município, como um espaço da descentralização.

O território, ou seja, o distrito significa a área de abrangência de uma unidade ambulatorial de saúde e delimita-se em função do fluxo da assistência em saúde, dos trabalhadores de saúde e da população num determinado território. O distrito é, sobretudo, um território de determinação das co-responsabilidades pela saúde naquele espaço entre população e serviço, mas, também, um espaço de organização básica da prática da atenção à demanda.

As implicações desta estrutura à situação de trabalho dos profissionais de saúde, são que há o aumento substancial da demanda de atenção e assistência à população adstrita de cada unidade básica sob a gerência de um determinado distrito, pois o vínculo com a população torna-se maior. Assim, os trabalhadores sofrem a tensão e exigências da população e da administração, que se tornam cada vez mais presentes.

Nestes momentos, a população e os trabalhadores necessitam então ser mais esclarecidos sobre o processo de trabalho e a gerência adotar uma liderança que permita o desenvolvimento desta dinâmica social que caracteriza o trabalho em saúde coletiva. Embora nem sempre isto seja observado, é preciso repensar e reconstruir o processo de trabalho e rever as condições para proporcionar respostas mais satisfatórias aos problemas que surgem.

Em relação aos conceitos-chave de distritos sanitários, Mendes (1995, p. 187) ressalta que a concepção de sistemas de serviços de saúde tem sido posta como possibilidade "integradora" que permita uma gestão eficiente dos serviços. 
Ou seja, no plano macro, a configuração de sistemas de saúde superaria a pluralidade institucional e "reintegraria", sob uma política única, o conjunto de instituições que foram desenvolvidas ao longo da história em saúde coletiva.

A seguir, descreve-se especificamente sobre a unidade de saúde estudada, para maior compreensão do processo de trabalho estabelecido.

\section{Caracterização da UBS e do trabalho de enfermagem}

Schraiber; Nemes; Mendes (2000, p .279) citam que a Unidade Básica de Saúde (UBS) é conhecida como a porta de entrada do sistema que oferece cuidados básicos de saúde, incluindo atenção integral e referenciando os casos mais complexos para os demais níveis (secundário e terciário) de atenção em saúde.

A UBS selecionada neste estudo está localizada em uma comunidade com aproximadamente 16.000 habitantes, residentes em um bairro do município que procuram diariamente seus serviços e estabelecem uma relação muito próxima com os profissionais, uma vez que estes assistem a saúde destas pessoas em diferentes momentos de suas vidas.

As atividades no atendimento à clientela compreendem as consultas médicas em clínica (dois clínicos), pediatria (dois pediatras), ginecologia (dois ginecologistas) e pré-natal; o atendimento de enfermagem corresponde à préconsulta no pré-natal, coleta de material em ginecologia e para exames laboratoriais, curativos, nebulização, teste do pezinho, visitas domiciliares, imunização, orientações às medicações prescritas aos usuários, verificação de 
pressão arterial e curativo.

A equipe de enfermagem é composta por um enfermeiro e quatro auxiliares de enfermagem. O enfermeiro exerce a função de gerente da unidade, mas também atua na assistência, motivado pela sobrecarga de trabalho dos auxiliares, por vezes então, substituindo-os em alguns momentos dos atendimentos.

Atuam também na instituição três recepcionistas e uma funcionária da limpeza.

Com vista à discussão da situação de trabalho da equipe de enfermagem, cabe a descrição das atividades com a respectiva divisão das tarefas, horária e jornadas. Estes dados foram obtidos mediante entrevista com a gerente da UBS.

O horário de funcionamento da unidade é de $7 \mathrm{~h}$ às $17 \mathrm{~h}$, de segunda-feira a sexta-feira, com atuação da equipe multiprofissional nas atividades programadas de saúde, que são desenvolvidos em salas específicas.

A atuação dos profissionais de enfermagem realiza-se por escala de serviço como diaristas, com carga horária em torno de 40 horas semanais. Dos diaristas, quatro trabalham das $7 \mathrm{~h}$ às $12 \mathrm{~h}$ e de $13 \mathrm{~h}$ às $16 \mathrm{~h}$ horas, sendo que um deles trabalha de $8 \mathrm{~h}$ às $13 \mathrm{~h}$ e de $14 \mathrm{~h}$ às $17 \mathrm{~h}$. Houve um acordo entre eles que o horário de duas horas concedidas para o almoço seria de apenas uma hora, pois possibilitaria uma antecipação no horário de saída. Conforme a gerente de enfermagem, sempre há o rodízio dos funcionários nas atividades, este é definido conforme a necessidade da demanda e assistência à clientela e ao serviço.

As atividades da enfermagem são desenvolvidas nos seguintes setores da unidade: sala de vacinação, sala de nebulização, sala de curativos, sala de 
ginecologia e pré-natal, farmácia e sala de preparo e esterilização de material.

Os setores anteriormente descritos foram objetos de análise ergonômica deste estudo e serão mais bem detalhados na análise de espaços e equipamentos posteriormente neste capítulo. A UBS, em sua estrutura, também conta com consultórios clínicos e de pediatria, recepção, sala da gerente da unidade, copa/cozinha e sala de reunião. Porém, para a análise ergonômica, foram considerados os postos de trabalho nos quais a enfermagem efetivamente atua.

A gerente da instituição informou que os profissionais de enfermagem têm formação de nível técnico, mas foram efetivados como auxiliares de enfermagem, com exceção de apenas um deles. Este fato ocorreu de acordo com o concurso público à época de sua efetivação. Ela destacou ainda um alto índice de saída dos profissionais para outras unidades do Distrito Sanitário IV, uma vez que são freqüentemente convocados pela gerente do Distrito para substituir eventuais faltas e/ou licenças de outros profissionais de enfermagem em outras unidades do mesmo Distrito. Assim, observou-se que a UBS conta com a presença efetiva de apenas três e às vezes duas profissionais de enfermagem que se revezam entre as tarefas descritas.

O Ministério da Saúde, através do Conselho Nacional de Saúde (CNS), discutiu os problemas da gestão do trabalho em saúde, chamando a atenção que em um mesmo local de trabalho dos serviços públicos de saúde muitas vezes havia trabalhadores com direitos de deveres diferenciados. Foi mencionado que este fato é causador de desestímulo profissional, dos desvios de funções e das duplas ou triplas jornadas de trabalho (BRASIL. MS., 2003, p. 15). 
Neste sentido, elaborou e discutiu, de forma ampla e democrática, os princípios e diretrizes para Norma Operacional Básica (NOB) de recursos humanos para o SUS, divulgando e estabelecendo estratégias para o fortalecimento e aplicação da legislação vigente sobre a gestão pública do trabalho. Estes devem ser implementados nas práticas e processos de trabalho em saúde, nos três níveis governamentais, ou seja, federal, estaduais e municipais.

Retornando as especificidades da UBS, a gerente da unidade relatou também que as licenças médicas têm por causas o adoecimento do profissional por hipertensão arterial, acompanhamentos de filhos, entre outros. Há queixas constantes de dores na coluna, mas estas não geram afastamentos.

As variáveis relativas às relações de trabalho remetem às questões mais facilmente perceptíveis. Neste sentido, a jornada de trabalho, o tipo de contrato de trabalho, a forma de pagamento, o horário, a exigência de conhecimentos técnicos, sistema de incentivos, forma de controle sobre os trabalhadores, tempo de folga, local para as refeições e condições ambientais, existência de banheiros, serviços de atenção à sua saúde são aceitos como determinantes da qualidade de vida e condições de saúde do trabalhador (PICALUGA, 1983, p. 38).

O confronto das situações citadas ocasiona o desgaste da saúde, acrescidas das suas condições de vida, relações de trabalho e formas de atividade laboral. Assim, o adoecimento da equipe de enfermagem que foi constatado é relevante e merece atenção e intervenção.

O enfermeiro chefe da unidade tinha como atividades, dentre outras, a organização da escala da equipe de enfermagem, preenchimento de estatísticas e 
respostas às solicitações da SMS e gerente do Distrito Sanitário. No momento da entrevista, o trabalho era administrativo, foram utilizados fichas e papéis para anotações.

Witt (2005, p. 235), em sua tese sobre as competências da enfermeira em atenção básica, argumenta que essa profissional é capaz de assumir a gerência e gestão dos serviços e fazer o gerenciamento e administração, tanto da força de trabalho em saúde quanto dos recursos físicos, materiais e de informação, responsabiliza-se pela atenção à saúde e contribui para sua organização; e coordena a equipe de enfermagem. Da mesma forma, planeja e sistematiza a assistência de enfermagem. Esta competência é necessária para a obtenção de resultados relacionados à implementação de políticas em saúde coletiva.

A equipe de enfermagem recebe um benefício trimestral, denominado Gratificação de Incentivo ao Desempenho - GID, que corresponde a duzentos e setenta reais ( 116,28 dólares). A Prefeitura do município estabeleceu critérios para o recebimento do benefício, entre eles a presença diária na unidade é pontuada.

Quanto ao treinamento da equipe, ocorre somente quando há necessidades especiais.

Dentre os problemas identificados pela gerente da instituição estavam: falta de material para curativo, inexistência de óculos de proteção para todos, insuficiente número de trabalhadores de enfermagem (apenas quatro e às vezes três trabalhadores para atender toda a clientela), baixos salários e a sobrecarga de trabalho. 
Para exercer plenamente suas competências gerenciais e contribuir para as funções essenciais em saúde coletiva, a enfermeira precisa estar motivada, porém o dado relacionado à falta de treinamento da equipe, falta de materiais, dimensionamento insuficiente, sobrecarga e baixos salários são determinantes para o seu desgaste profissional. Esta situação gera desestímulos no desenvolvimento do trabalho, com repercussões negativas nos resultados, no desempenho profissional e, conseqüentemente, no processo de trabalho em saúde coletiva que se torna fragmentado e de resolução frágil.

Isso constitui um desafio ao profissional de enfermagem que encontra dificuldades de implementar suas ações de forma plena e digna. A integralidade pressuposta para as ações em saúde coletiva demanda esforços em conjunto para o seu alcance, ou seja, de todos os envolvidos, gestores, população e profissionais. Demanda, ainda, educação e informação.

A Portaria $\mathrm{n}^{\circ} 198$ do Ministério da Saúde de 13 de fevereiro de 2004 instituiu a Política de Educação Permanente como estratégia do SUS para formação e o desenvolvimento de trabalhadores para o setor e deu outras providências (BRASIL. MS., 2004).

Esta política considera a necessidade de educação permanente dos profissionais de saúde, propõe a formação de Pólos de Educação Permanente, como instância deliberativa de decisões nesta área, a partir da interlocução com os diversos atores que confrontam o cenário da saúde coletiva, entre esses, as instituições formadoras em saúde, o controle social (Conselhos Municipais de Saúde), estudantes da área de saúde, profissionais de saúde e gestores. 
Nesta perspectiva, a educação e a informação são objetos de constantes reflexões da prática profissional e do agir em saúde, como uma forma de melhor entender e transformar o processo de trabalho.

O município, local deste estudo, é sede do Pólo de Educação Permanente da Região Sul do Estado do Rio de Janeiro. Encontrava-se em fase de construção desta política, o que poderá representar um avanço para as questões do trabalho e da educação.

Outro depoimento importante da gerente foi que os trabalhadores de enfermagem queixam-se de maus tratos pelos usuários, sendo que por diversas ocasiões identificou atos de violências verbais.

Ao analisar a violência contra os trabalhadores ou de outra forma, a violência e suas relações com o trabalho, percebeu-se a tendência em estudos brasileiros em distinguir a violência do trabalho da violência no ambiente de trabalho.

Nessa distinção, a violência do trabalho, que pode ser enquadrada no que Minayo (1994, p. 7) denominou de "violência estrutural", refere-se àquela que assola os trabalhadores quando são submetidos a condições e ambientes de trabalho insalubres, ou seja, àquela que se origina no modo de produção e na organização do processo de trabalho e que causa desconforto, sofrimento, desgaste, fadiga e adoecimento.

A violência no trabalho ou no ambiente de trabalho, que está incluída no que Minayo (1994, p. 7) classificou como "violência da resistência" ou "violência do comportamento" e como "violência da delinqüência", refere-se exatamente a 
comportamentos violentos, praticados por uma pessoa ou por um grupo de pessoas, sejam elas externas ao trabalho, internas ou que tenham alguma relação com o trabalho (clientes e pacientes).

A gerente busca enfrentar estas questões, ouvindo a equipe e encaminhando os problemas administrativos à gerência do distrito sanitário e esta à secretaria de saúde, embora as respostas sejam lentas e, às vezes, inexistentes. 
5.2 Os trabalhadores de enfermagem e os fatores determinantes das condições de trabalho

Foram entrevistados os profissionais de enfermagem que atuavam na UBS, cujo perfil está apresentado na Tabela 1.

Tabela 1 - Dados biográficos dos profissionais de enfermagem. Volta Redonda RJ, 2005.

\begin{tabular}{|c|c|c|c|}
\hline Indicadores & Variáveis & $\mathbf{f}$ & $\%$ \\
\hline Sexo & $\begin{array}{l}\text { Feminino } \\
\text { Masculino }\end{array}$ & $\begin{array}{l}04 \\
-\end{array}$ & $\begin{array}{c}100 \% \\
-\end{array}$ \\
\hline $\begin{array}{l}\text { Categoria } \\
\text { Profissional }\end{array}$ & $\begin{array}{l}\text { Técnico de Enf. } \\
\text { Auxiliar de Enf. }\end{array}$ & $\begin{array}{l}01 \\
03\end{array}$ & $\begin{array}{l}25 \% \\
75 \%\end{array}$ \\
\hline Estado Civil & $\begin{array}{l}\text { Solteiro } \\
\text { Casado } \\
\text { Amigado }\end{array}$ & $\begin{array}{l}01 \\
02 \\
01\end{array}$ & $\begin{array}{l}25 \% \\
50 \% \\
25 \%\end{array}$ \\
\hline Escolaridade & $\begin{array}{l}2^{\circ} \text { grau completo } \\
\text { Superior completo }\end{array}$ & $\begin{array}{l}03 \\
01\end{array}$ & $\begin{array}{l}75 \% \\
25 \%\end{array}$ \\
\hline Idade & $\begin{array}{l}35-40 \\
41-46\end{array}$ & $\begin{array}{l}02 \\
02\end{array}$ & $\begin{array}{l}50 \% \\
50 \%\end{array}$ \\
\hline
\end{tabular}

A população trabalhadora de enfermagem na UBS é composta por quatro trabalhadoras e predomina o sexo feminino, o que histórica e culturalmente ocorre na categoria de enfermagem. Almeida e Rocha (1997, p. 18), ao abordarem sobre 
o trabalho de enfermagem, ressaltam que é uma ação ou atividade realizada predominantemente por mulheres que precisam dela para reproduzir a sua própria existência e utilizam um saber advindo de outras ciências. Reflete uma síntese de suas ações para apreender o objeto da saúde, visualizando o seu produto final: atender às necessidades sociais, ou seja, a promoção da saúde, prevenção de doenças e a recuperação do indivíduo, ou o controle da saúde da população.

Quanto ao estado civil, duas (50\%) são casadas, uma solteira (25\%) e uma declarou estar amigada (25\%). Possuem o nível médio, o curso técnico em enfermagem, porém na busca de outro saber, uma das trabalhadoras relatou ter concluído o Curso Superior de Pedagogia.

Em relação à idade, possuíam entre 35 a 40 anos (50\%) e 41 a 46 anos $(50 \%)$.

Quadro 1 - Dados antropométricos das trabalhadoras de enfermagem da UBS.Volta Redonda -RJ, 2005.

\begin{tabular}{|c|c|c|c|}
\hline Altura & Peso & IMC & Altura nível do \\
& & & cotovelo \\
\hline $1,56 \mathrm{~m}$ & $105,0 \mathrm{~kg}$ & 43,15 & $95,0 \mathrm{~cm}$ \\
& & & $95,5 \mathrm{~cm}$ \\
\hline $1,54 \mathrm{~m}$ & $60,5 \mathrm{~kg}$ & 25,51 & $103,5 \mathrm{~cm}$ \\
\hline $1,52 \mathrm{~m}$ & $67,0 \mathrm{~kg}$ & 28,99 & $95,5 \mathrm{~cm}$ \\
\hline $1,55 \mathrm{~m}$ & $55,0 \mathrm{~kg}$ & 22,89 & \\
\hline
\end{tabular}


Além dos valores de peso e altura dos sujeitos, a altura ao nível do cotovelo é relevante para o planejamento das bancadas de trabalho, pois estas devem ser construídas com base no tamanho do trabalhador e no tipo de trabalho a ser executado (MARZIALE, 1995, p. 61).

Conforme Quadro 1, a altura em nível de cotovelo da equipe de enfermagem, verificada na posição de pé, variou entre 95 a 103,5 cm. A média das alturas é igual a 97,4 cm. Segundo Grandjean (1998, p. 46), em trabalhos essencialmente manuais em pé, as alturas recomendadas são de 5 a $10 \mathrm{~cm}$ abaixo da altura dos cotovelos. Portanto, as bancadas dos postos de trabalho devem ter altura entre 82,4 a $92,4 \mathrm{~cm}$.

Os resultados indicam, ainda, em relação ao Índice de Massa Corporal (IMC), os valores considerados normais estão entre 18,5 a 24,9 , sendo os valores 25,0 a 29,9 considerados de sobre peso e 30,0 a mais considerados de obesos. Calculou-se o IMC considerando-se a razão peso atual $(\mathrm{kg})$ e o quadrado da estatura $\left(\mathrm{m}^{2}\right)$ (SAMPAIO; FIGUEIREDO, 2005, p. 55).

Assim, constatou-se que $50 \%$ das trabalhadoras estão com sobre peso e $25 \%$ obesas. A obesidade é um determinante importante de risco e conseqüência à saúde.

Recentemente, ao fazer um estudo de prevalência de doença arterial coronariana em pacientes portadores de lesões orovalvulares, no Instituto Estadual de Cardiologia Aloysio de Castro no Rio de Janeiro, observou a relação dos diversos fatores de risco e a doença coronariana na população obesa. Os indivíduos obesos estão predispostos a distúrbios metabólicos que envolvem a 
hipercolesterolemia, hipertrigliceridemia, diabetes e doenças respiratórias. (CORREA; KRUCZAN, 2004, p. 71)

A obesidade, o tabagismo, o diabetes, a hipertensão arterial sistêmica, as dislipidemias são fatores de risco muito conhecidos para as doenças das artérias coronárias, principais causas de cardiopatia e morte cardíaca (CORREA; KRUCZAN, 2004, p. 71)

É preciso pontuar as maneiras de preveni-la e tratá-la. Os padrões alimentares e ambiente alimentar estão incluídos na prevenção e controle do sobre peso e obesidade. Indica-se, portanto, um acompanhamento nutricional e de saúde às trabalhadoras, neste estudo.

\section{Experiência profissional}

Em relação ao tempo de serviço na enfermagem e tempo de serviço na UBS foi constatado que elas possuem tempo de serviço na profissão entre 13 e 19 anos e atuam na unidade em período entre 5 anos e 5 meses a 17 anos e 5 meses, conforme mostra o Quadro 2. 
Quadro 2 - Distribuição do tempo de serviço na enfermagem e na unidade das trabalhadoras entrevistadas. UBS - Volta Redonda -RJ, 2005.

\begin{tabular}{|c|c|c|}
\hline Categoria Profissional & $\begin{array}{c}\text { Tempo de serviço na } \\
\text { enfermagem }\end{array}$ & $\begin{array}{c}\text { Tempo de serviço na } \\
\text { UBS }\end{array}$ \\
\hline Técnico de Enfermagem & 19 anos & 5 anos e 5meses \\
\hline Auxiliares de Enfermagem & 25 anos & 17 anos e 5 meses \\
& 19 anos & 6 anos \\
\hline
\end{tabular}

Os dados encontrados permitiram inferir que houve pouca rotatividade entre as participantes da pesquisa e, por isso, o tempo de serviço na mesma atividade é um fator relevante a ser analisado no presente estudo.

\section{Salários}

O salário era variável em relação à categoria profissional. As auxiliares de enfermagem recebem 2 salários mínimos e a técnica de enfermagem 3 salários mínimos. O valor do salário mínimo no Estado do Rio de Janeiro varia entre os valores de R\$ 310,00 a R\$ 373,00 (RIO DE JANEIRO, 2005) (Disponível em: http://www.portalbrasil.net/salariominimo), correspondente a 133,51 a 373 dólares.

Sobre o número de elementos na família, uma das auxiliares mora sozinha e as demais variou entre três a seis componentes. A técnica de enfermagem conta com dois elementos em sua família. É evidente que estes dados influenciam na 
renda familiar, pois as que têm outros elementos na família, entre as auxiliares, uma aumenta a renda para 3 a 4 salários e a outra para 9 salários mínimos, uma vez que conta com o salário do esposo e pensão de sua mãe. A técnica de enfermagem aumenta para 5 a 6 salários mínimos.

Apenas uma das respondentes possui outro emprego, a que possui o ensino superior, que como pedagoga trabalha uma vez por semana em 4 horas aulas semanais, como supervisora de uma instituição estadual.

O segundo emprego ocorre tanto entre os enfermeiros como entre os auxiliares de enfermagem e tem como principal motivação as necessidades econômicas familiares ou para ampliar o patrimônio familiar (COCCO, 1997)

Na unidade, o pessoal de enfermagem cumpre escala de oito horas diárias. Esta realidade dificulta manter um segundo emprego. Houve ainda o relato de uma das auxiliares de que “... não dá tempo, saio daqui morta”.

O Consejo Internacional de Enfermera (CIE) (1986, p. 9) aponta estes fatores como grandes geradores de estresse no ambiente de trabalho, pois provocam alto nível de suas responsabilidades, descontrole no processo decisório, conflitos funcionais e cansaço por excesso de horas trabalhadas.

Corroborando com os achados, Silva (2000, p. 96) constata que, na enfermagem, os fatores atribuídos aos riscos psíquicos são atenção constante, supervisão acirrada, ritmo intenso de trabalho, trabalho repetitivo, ausência de comunicação e de criatividade.

Verifica-se, neste estudo, a vulnerabilidade das profissionais de enfermagem a esses fatores, destacando-se o baixo salário e a jornada de trabalho diária com 
repercussões em sua vida social e familiar.

\section{Satisfação no trabalho}

Em relação à satisfação no trabalho, as profissionais de enfermagem demonstram em $50 \%$ sua insatisfação, atribuída ao baixo salário por uma e a outra porque gostaria de trabalhar em emergência. Constatou-se que $50 \%$ evidenciaram dúvidas, assinalando a satisfação e a insatisfação também. Justificaram que estavam satisfeitas porque faziam o que gostava, mas insatisfeitas pelo baixo salário e pela falta de condições de trabalho, ressaltando que falta funcionário, materiais e Equipamentos de Proteção individual (EPI).

Estes dados corroboram com os achados de Farias (2004, p. 103) que, em sua pesquisa em Centro Municipal de Saúde no Estado do Rio de Janeiro, verificou o relativo descontentamento da equipe quanto a esse aspecto, ou seja, de remuneração. As tarefas desenvolvidas na unidade de saúde pública eram as mais diversificadas e giravam em torno do atendimento à clientela, nos diversos programas de Saúde Pública. O que acontecia, de maneira geral, era a falta de pessoal disponível para o atendimento como referido pelos próprios sujeitos do estudo. Existia a possibilidade de contratação, enquanto não ocorria o concurso público. No entanto, pelos baixos salários, era relativamente pequena a procura, de acordo com as necessidades de pessoal. A sobrecarga de trabalho para alguns foi também referida.

Segundo Martinez; Paraguay; Latorre (2004, p. 56), satisfação no trabalho é um fenômeno complexo e de difícil definição. Por se tratar de um estado subjetivo, pode variar de pessoa para pessoa, de circunstância para circunstância e ao longo do tempo para a mesma pessoa. 
Para Dejours (1999, p. 34), existem situações em que os sujeitos lutam contra as adversidades da organização e se esforçam para fazer o melhor, pondo nisso muita energia, paixão e investimento pessoal. É natural, então, que esperem receber reconhecimento, porém, quando isto não acontece, é motivo de sofrimento.

Segundo o mesmo autor, do reconhecimento depende, na verdade, o sentido do sofrimento. Ao ter reconhecido o seu trabalho, o esforço, a angústia e as decepções e o medo vivenciado adquirem um outro sentido.

Assim, as novas tendências do mercado de trabalho, de acordo com Mauro et al. (2004, p. 341), estão relacionadas às condições ocupacionais e devem considerar a remuneração, oportunidade de carreira, garantia disciplinares, horas de trabalho, descanso e férias, segurança social, proteção à saúde, oportunidade de formação inicial e educação contínua, efetivo de pessoal no serviço, organização do trabalho, participação do pessoal na determinação de suas condições ocupacionais e de vida e participação em tudo que contribui para sua satisfação no trabalho.

\section{Qualidade de vida}

Das trabalhadoras de enfermagem da UBS, $50 \%$ possuem casa própria quitada e 50\% residem em casa alugada. Neste mesmo percentual, duas residem próximas à Unidade de Saúde, relatando um tempo de cinco a dez minutos para chegar até a mesma. Duas residem mais distante, apontando trinta minutos e uma hora entre sua residência e a unidade. A maioria (90\%) utiliza ônibus como meio de transporte e apenas uma tem carro próprio, sendo esta a que possuía o curso superior em pedagogia. 
Sobre o lazer, $90 \%$ relatam realizar atividades de lazer, o que foi traduzido em assistir a shows oferecidos pela Prefeitura, clube, viagens a passeio e à família.

A alimentação é referida ser feita em horário regular (90\%), uma vez que ressaltaram que é oferecida uma hora de almoço. Valer destacar que uma delas (10\%), salienta que o horário de alimentação é irregular, visto que cotidianamente não é respeitado, pois passa do horário normal, em função do trabalho.

A enfermagem desenvolve suas atividades em um mundo do trabalho e de vida que nem sempre é favorável à boa qualidade de vida. Assim, o profissional necessita de duplo emprego ou de uma renda familiar que proporcione melhores condições.

Farias (2004), em sua tese sobre a qualidade de vida no trabalho do profissional de enfermagem em Saúde Pública, verificou que a equipe de enfermagem considerou precária sua qualidade de vida no trabalho, pois sofria interferência do processo de trabalho e a sua organização apontando as condições precárias de trabalho como o espaço físico, relacionamento interpessoal, comunicação deficiente, remuneração insatisfatória, multiplicidade de empregos, excesso de demanda e a violência, dentre outros fatores, responsáveis por tal acepção. Assim, existiu a compreensão de que a responsabilidade para o alcance da qualidade de vida sofre grande influência do próprio contexto do trabalho.

Leopardi (1999, p. 49) ainda assevera que o estudo da organização do trabalho antecede toda análise sobre a qualidade de vida dos trabalhadores, principalmente pelo contexto histórico do capitalismo e as suas peculiaridades quanto à produção, submetendo-os às diversas formas de pressão, tanto psíquicas quanto físicas, pela ação 
das cargas laborais, pelas condições laborais e salários desproporcionais e insuficientes nas ações empreendidas.

Notou-se que na UBS existia uma preocupação em termos de horário para equilíbrio entre o trabalho e o convívio familiar. Porém, a inviabilidade em termos salariais impulsionava-os em busca de outro emprego ou de dúvidas em relação à satisfação no trabalho, conforme anteriormente descrito. Estes fatos merecem atenção dos órgãos empregadores e esferas governamentais, principalmente, por ser a instituição incluída na rede pública de assistência. Portanto, sua qualidade de vida laboral e social eram insatisfatórias, o que pode ocasionar conseqüências diretas no estado de saúde das profissionais.

\section{Problemas de saúde}

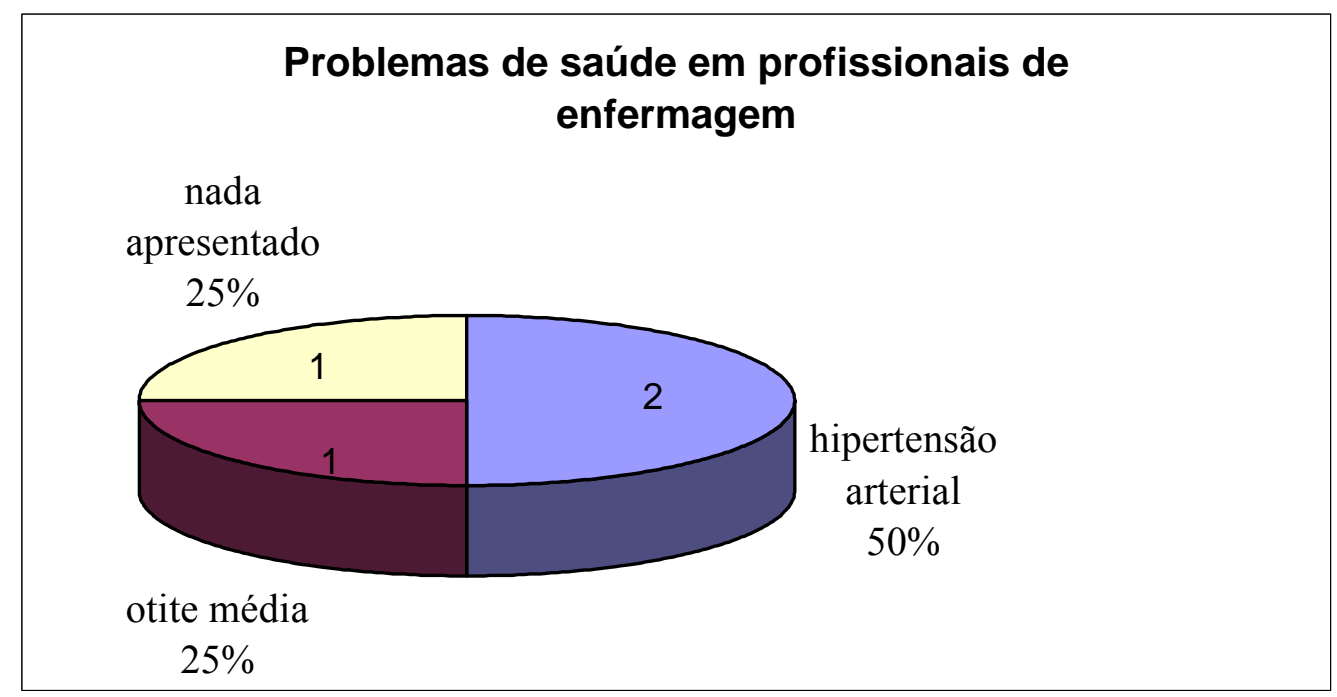

Figura 3 - Condições de saúde dos profissionais de enfermagem na UBS. Volta Redonda-RJ, 2005 
Os problemas de saúde relatados são hipertensão arterial (50\%), acompanhado de obesidade. As causas apontadas são estresse por muito tempo de serviço e por trocas constantes na UBS, ou seja, convocação do Distrito Sanitário para atender à falta de pessoal de enfermagem em outras unidades de saúde. As trabalhadoras apresentam a doença há três anos e há mais de dez anos e fazem uso de medicações específicas.

O diagnóstico de otite média foi respondido por uma das trabalhadoras que convive com a situação desde a infância. Revelou perda auditiva em exame auditivo, o que não é valorizado pela mesma. Necessita de cirurgia para correção, que pretende realizar em breve.

Na UBS, as profissionais de enfermagem não reconhecem os problemas de saúde provocados pelo trabalho. Apenas uma delas apontou esta relação, ressaltando que a quantidade de atendimento é elevada, o que atribui à carência da população que necessita dos serviços diários da UBS. Esta demanda excessiva gera estresse e pode ser um fator de vulnerabilidade para os problemas de saúde descritos.

Murofuse (2004, p. 243), em sua tese sobre o adoecimento entre trabalhadores de enfermagem, confirmou o acometimento dos profissionais por patologias graves e evidenciou que a força de trabalho da enfermagem estava sendo consumida por problemas de saúde que afetavam seus corpos e a mentes, decorrentes de enfermidades denominadas doenças da modernidade, entre as quais o estresse e a hipertensão arterial.

Constatou-se na UBS pesquisada estas enfermidades, confirmadas pelos elevados índices de afastamentos do serviço e insatisfações, repercutindo no adoecimento e na falta de atenção ao estado de saúde das trabalhadoras que, 
necessariamente, deveriam estar sendo atendidas para tratamento e monitoramento.

A maioria delas $(90 \%)$ relata não ter sofrido acidentes de trabalho durante os últimos doze meses. Apenas um acidente ocorreu na sala de imunização, há 10 meses, provocando contato da vacina Sabin nos olhos, o que, segundo a trabalhadora, foi ocasionado pela mudança da embalagem.

Napoleão e Robazzi (2003, p. 60), em estudo sobre acidentes de trabalho entre trabalhadores de enfermagem, ressaltam que proporcionar dados relativos ao número de acidentes de trabalho, analisar a sua distribuição segundo características da ocorrência e das vítimas e apresentar os resultados constituem base indispensável para a indicação, aplicação e controle de medidas prevencionistas.

Faz-se importante lembrar que a sub-notificação das ocorrências de acidentes de trabalho é comum, motivada pelas dificuldades que os trabalhadores encontram para a comunicação e a assistência. Uma das participantes relatou sobre um acidente de trabalho ocorrido há muito tempo atrás, no setor de UBS, reforçando os descaminhos que teve que enfrentar, ao registrar o ocorrido.

Esta abordagem merece consideração, uma vez que, ao analisar a descrição do acidente na UBS, verificou-se a necessidade de adoção de medidas educativas para sua prevenção. As mudanças tecnológicas dos materiais a serem usados nos procedimentos devem ser comunicadas e orientadas adequadamente, como norma de segurança para evitar os acidentes.

Neste sentido, a implementação das diretrizes propostas pelo Ministério da Saúde (BRASIL.MS., 2005) para gestão do trabalho no SUS deve ser objeto da política municipal no setor saúde. 


\section{Violência no trabalho}

A violência no trabalho tem sido um acontecimento constante nos serviços de saúde, motivada pela demanda excessiva de atendimentos que, de forma contraditória, é executada por um número escasso de profissionais. Estes trabalhadores enfrentam a exigência dos usuários que, independente das questões administrativas de dimensionamento de pessoal, querem respostas imediatas e atendimento eficaz. A UBS teve esta realidade presente no trabalho da equipe de enfermagem.

Farias (2004), em estudo realizado em centro municipal de saúde, também evidenciou situações de violência no trabalho. Vigoravam aquelas geradoras de grande estresse, no ambiente de trabalho, interferindo, portanto, na carga mental dos trabalhadores. Os clientes, por diversas vezes, não se conformavam com a informação dada pelo profissional de enfermagem da ausência de número para consulta, forçando $\mathrm{o}$ atendimento, inclusive com pronunciamento de palavrões.

Nos relatos das trabalhadoras de enfermagem (90\%), a agressão verbal ocorre de forma constante pelos usuários para com as profissionais da unidade. Estes dados corroboram com o depoimento da gerente da unidade apresentado anteriormente. Foram mencionados os termos xingamentos e expressões verbais agressivas como atitudes dos usuários. Muitas vezes, houve a presença de usuários alcoolizados ou drogados na unidade que reforçavam este comportamento. Apenas uma das respondentes não apontou tal situação.

De acordo com os dados obtidos, evidenciou-se a consciência, da maioria das trabalhadoras, acerca da falta de segurança na unidade. 
Com base nas classificações de violência de Minayo (1994, p. 7) e de Palácios (2003, p. 214), pode-se afirmar que, neste estudo, os tipos de violência no trabalho enfrentados pela equipe de enfermagem foram do tipo estrutural e psicológica.

Constatou-se que as formas de violência operantes no mundo do trabalho de enfermagem dessa UBS são também do tipo estrutural/institucional e comportamental/relacional (COSTA, 2005). Estas especificavam em violência estrutural; violência repressiva; violência alienação e em violência clássica, ratificam os achados do mesmo autor.

Os determinantes da violência no trabalho na unidade pesquisada são o aumento da utilização dos serviços da unidade por criminosos e usuários agressivos pelo uso de drogas e álcool; os fatores considerados situacionais e a movimentação de pessoas sem restrição pela falta de segurança no local; a interrupção do trabalho durante alguns períodos como, por exemplo, no horário de alimentação, apesar do rodízio entre elas, o que nem sempre é respeitado pela população que exige atenção. E, ainda, a diminuição do número de trabalhadores para atender às necessidades de outras unidades do distrito; o dimensionamento inadequado dos profissionais; a falta de treinamento específico sobre as questões da violência para reconhecer e melhor controlar o estresse e a insatisfação no trabalho; a personalidade; a capacidade e cultura profissional e do ambiente de trabalho em relação à violência e a comunicação inadequada.

Santos Júnior e Dias (2004, p. 48) refletem que, apesar da violência no trabalho estar se tornando um fenômeno alarmante em todo o mundo, 
especialmente para os trabalhadores da saúde, acredita-se na sua minimização por meio de medidas preventivas não podem ser pontuais nem eventuais.

Ressaltam que enquanto o número de trabalhadores não for suficiente para o atendimento da demanda de usuários que procuram por assistência à sua saúde, enquanto esses usuários não tiverem um acolhimento adequado e respostas resolutivas de seus problemas, enquanto as condições de trabalho dos profissionais que atuam na área de assistência à saúde não forem adequadas, enquanto a comunidade não for educada para entender que o cuidado com a saúde pressupõe medidas de promoção e prevenção da saúde e não houver a exclusiva procura por unidades de atendimento de urgências e emergências, e, principalmente, enquanto as condições gerais de vida da população não forem melhoradas ou enquanto houver um enorme distanciamento entre a opulência e a indigência, o problema da violência no trabalho no setor saúde não terá solução.

Com base no referencial teórico-metodológico desta tese, confirmou-se a necessidade de aplicar medidas para enfrentar e reconhecer a violência no trabalho, de forma a reduzi-la ou minimizá-la, com intervenções no processo de trabalho.

\section{Disposição para o trabalho}

$\mathrm{Na}$ equipe de enfermagem $(90 \%)$ houve relato de disposição para o trabalho realizado, o que está atribuído ao fato de procurarem vir para o trabalho de "bem com a vida". Certamente, os seus valores de vida e de trabalho têm influenciado como uma marca significativa o desenvolvimento de suas atividades. 
Cezar (2005) chama a atenção para o fato de que a violência das condições insatisfatórias de trabalho leva as trabalhadoras a se desviarem de suas situações específicas para garantir a realização das atividades assistenciais. Assim, afeta a todos os componentes da equipe de saúde indistintamente, causando danos de formas diversas. Dessa forma, embora sugestionados pela fascinação dos instrumentos de trabalho, a dura realidade cotidiana mostra que também estes não estão disponíveis conforme a necessidade de seus usos. Desse modo, a violência das condições precárias de trabalho afetando o seu corpo.

Ressalta-se um relato (10\%) de que fisicamente trabalhando na unidade, a profissional sente-se cansada.

Cabe evidenciar que esta profissional era portadora de hipertensão arterial. Notou-se, então, que a situação de seu trabalho e de sua vida é determinante para seu problema de saúde. Apesar desta condição, ela somente é afastada do trabalho, quando apresenta picos hipertensivos.

A maioria (90\%) sente-se bem mentalmente durante o trabalho na unidade. Porém, uma depoente relatou cansaço sempre que a sala de espera ficava superlotada e com muita "falação". Segundo Grandjean (1998, p. 269), o ruído é tratado sob o ponto de vista da ergonomia, pois a via auditiva está ligada às estruturas de ativação ou alarme do cérebro. Seus efeitos estão em nível fisiológico e psicológico, causando perturbações da atenção, perturbações do sono e sensações de incômodos.

Destacou-se que as atividades desenvolvidas na UBS exigem concentração e atenção, o que foi reconhecido pelas trabalhadoras. Portanto, o ruído, como agente físico, foi analisado, visando minimizá-lo.

Oliveira e Lisboa $(2004$, p. 28$)$ ratificam que as formas de enfrentamento 
utilizadas pelos trabalhadores de enfermagem diante das exigências do dia-a dia no ambiente de trabalho precisam ser desveladas e analisadas, a partir da interlocução com estes trabalhadores, ao valorizarmos suas falas, vivências e experiências em seus serviços.

Os autores destacam que se precisa repensar o cuidado, a prática, porém sem esquecer do aspecto da saúde, do prazer e, porque não dizer, dos investimentos e suas repercussões na saúde mental ao lidar com as demandas do cliente e da estrutura organizacional (OLIVEIRA; LISBOA, 2004, p. 28).

As profissionais de enfermagem (50\%) fazem uso do fumo, relatando a quantidade de cinco a quinze cigarros por dia. As demais (50\%) não o fazem, porém houve o depoimento de uma de que parou de fumar há sete meses. Assim, é preocupante esta situação encontrada, especialmente correlacionando-as aos problemas de saúde verificados.

Quanto ao álcool, uma das trabalhadoras (10\%) assinala o uso socialmente, sendo uma vez por semana em casa. Não há relato de uso de outras drogas.

Neves (2002, p. 136) aborda aspectos do cuidado à saúde dos trabalhadores, alertando que é necessário encontrar formas de cuidado para promover a vida, para estimular a saúde. Reflete ainda sobre o processo de viver dos trabalhadores, destacando que se deve incentivá-los a alcançar o bem-estar e a melhor qualidade de vida possível.

Os aspectos da educação à promoção da saúde deve ser objeto de preocupação das lideranças de enfermagem e da própria equipe, a fim de repensar suas formas de vida e seus estilos adotados de vida para a manutenção da própria saúde. 


\section{Atividade de trabalho}

A Tabela 2 mostra as respostas das trabalhadoras de enfermagem quanto às suas atividades de trabalho.

Tabela 2 - Respostas dos profissionais de enfermagem na UBS quanto às tarefas em cada jornada de trabalho. Volta Redonda-RJ, 2005 excluir todas as linhas internas e laterais

\begin{tabular}{|c|c|c|c|}
\hline \multirow[t]{2}{*}{ Indicadores } & \multirow[t]{2}{*}{ Respostas } & \multicolumn{2}{|c|}{ Prof. de Enf } \\
\hline & & f & $\%$ \\
\hline Quantidade de tarefas & $\begin{array}{l}\text { Excessiva } \\
\text { Adequada }\end{array}$ & $\begin{array}{l}02 \\
02\end{array}$ & $\begin{array}{l}50 \% \\
50 \%\end{array}$ \\
\hline $\begin{array}{l}\text { Distribuição das tarefas } \\
\text { (em quantidade) }\end{array}$ & $\begin{array}{l}\text { Adequadas } \\
\text { Inadequadas }\end{array}$ & 04 & $\begin{array}{l}100 \% \\
-\end{array}$ \\
\hline Realização das tarefas & $\begin{array}{l}\text { Com esforço significativo } \\
\text { Sem esforço significativo }\end{array}$ & $\begin{array}{l}01 \\
03\end{array}$ & $\begin{array}{l}10 \% \\
90 \%\end{array}$ \\
\hline $\begin{array}{l}\text { Concentração para realizar } \\
\text { as tarefas }\end{array}$ & $\begin{array}{l}\text { Sim } \\
\text { Não }\end{array}$ & 04 & $\begin{array}{l}100 \% \\
-\end{array}$ \\
\hline Como considera & $\begin{array}{l}\text { Normais } \\
\text { Repetitivas } \\
\text { Imprevisíveis } \\
\text { Monótonas }\end{array}$ & $\begin{array}{l}01 \\
03\end{array}$ & $\begin{array}{r}10 \% \\
90 \% \\
- \\
-\end{array}$ \\
\hline
\end{tabular}

A análise dessa Tabela permite afirmar que, na UBS, as tarefas são 
consideradas adequadas (50\%) e excessivas $(50 \%)$ em cada jornada de trabalho, visto que depende do movimento de usuários. Torna-se excessiva quando o movimento é grande, quando há campanhas de vacinação e há falta de funcionários na unidade.

As depoentes não consideram que há esforço significativo para realização das tarefas $(90 \%)$. Porém, uma trabalhadora ressalta que: “... há deslocamento, várias vezes para buscar a ficha do usuário para realização do procedimento".

Foi reconhecida por toda equipe (100\%) a necessidade de concentrar a atenção para executar as tarefas. Citado que todas as tarefas exigem atenção, mas principalmente a de vacinação, no que se refere à quantidade, dosagem, validade e nomes das vacinas. As tarefas de coleta de material para o laboratório central e teste do pezinho também foram mencionadas como requerentes de atenção.

Esta situação está relacionada às cargas mentais e aos riscos ocupacionais. Mauro et al. (2004, p. 342) ressaltam que essas condições, insalubres na maioria das vezes, se tornam rotina, freqüentemente não percebidas pela equipe de enfermagem que se habitua com a situação ou mantém autocontrole dos sintomas, sem procurar esclarecer as causas verdadeiras.

Apontam, ainda, que um programa de educação continuada, com treinamento específico para profissionais de saúde, pode favorecer o entendimento destes problemas e de sua gravidade para combatê-los (MAURO et al., 2004, p. 343). Assim, é preciso uma política organizacional que atenda as reais necessidades dos trabalhadores. 


\section{Educação em serviço}

Dada a importância da educação em serviço, serão apresentados a seguir os relatos acerca desta condição. Nota-se que todas as trabalhadoras relataram não ter recebido treinamento inicial ao serem contratadas após a aprovação em concurso público, conforme a Figura 7. Fazem-se necessários programas de capacitação inicial, visando melhor adaptação e compreensão dos trabalhadores aos processos de trabalho.

Treinamento ao iniciar suas atividades na UBS

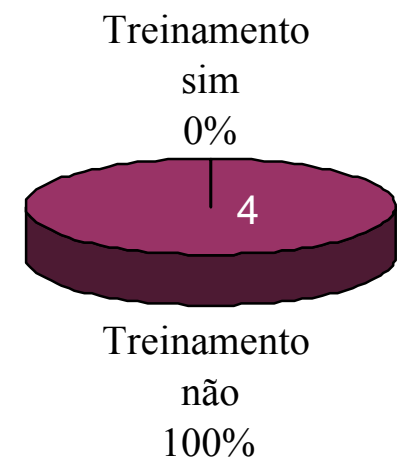

Figura 4 - Respostas dos profissionais de enfermagem na UBS em relação ao treinamento ao iniciar as atividades na UBS. Volta Redonda/RJ.2005.

A educação para a segurança dos trabalhadores, em habilidades, informações e conhecimentos, é fator essencial para a qualidade no trabalho, harmonia, bem-estar e melhor desenvolvimento do potencial dos profissionais. Porém, na UBS, não se verificou a implantação desta política, o que é preocupante. 


\section{Treinamento ao iniciar suas atividades na UBS}

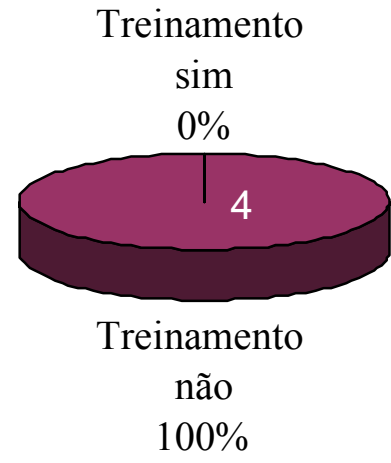

Figura 5 - Respostas dos profissionais de enfermagem na UBS em relação à educação em serviço. Volta Redonda/RJ, 2005

Farias (2004, p. 127) chama a atenção de que, nos tempos atuais, com a rapidez de informação e transformações sucessivas, no que se refere a mudanças no mundo moderno e à alta demanda, é utilizado, em vários momentos, o improviso para a realização das atividades, forçando o trabalhador a empregar mais a sua capacidade de concentração para não cometer erros. De certa forma, essa situação culmina com a ansiedade nos trabalhadores e contribui negativamente, em primeira instância, para os aspectos que proporcionam qualidade de vida no trabalho.

Um dos depoimentos mencionou que há necessidade de treinamento em imunizações e teste do pezinho, visando atualização nestas atividades.

Apenas uma das trabalhadoras reconhece receber educação em serviço, por ocasião da realização de reuniões, que ocorrem de seis em seis meses na SMS, sobre tuberculose e cuidadores de idosos.

Sobre este aspecto, a Política de Educação Permanente (BRASIL. MS, 2004) parte do pressuposto da aprendizagem significativa (que promove e produz 
sentidos) e propõe que a transformação das práticas profissionais possa estar baseada na reflexão crítica sobre as práticas reais de profissionais reais em ação na rede de serviços. A educação permanente é a aprendizagem no trabalho, em que aprender e o ensinar incorporam-se no cotidiano do trabalho.

A formação e o desenvolvimento englobam aspectos de produção de subjetividade, de habilidades técnicas, de conhecimento do SUS e um repensar e reconstruir o processo de trabalho em saúde coletiva.

\section{Material}

Em relação aos materiais utilizados na execução das atividades, verificaram-se os dados relativos à sua adequação quantitativa e qualitativa que são apresentados na tabela abaixo.

\begin{tabular}{|c|c|c|c|}
\hline \multirow[t]{2}{*}{ Indicadores } & \multirow[t]{2}{*}{ Respostas } & \multicolumn{2}{|c|}{ Prof. de Enf } \\
\hline & & $\mathbf{f}$ & $\%$ \\
\hline Materiais em quantidade & $\begin{array}{l}\text { Adequados } \\
\text { Inadequados }\end{array}$ & $\begin{array}{l}01 \\
03\end{array}$ & $\begin{array}{l}25 \% \\
75 \%\end{array}$ \\
\hline Materiais em qualidade & $\begin{array}{l}\text { Adequados } \\
\text { Inadequados }\end{array}$ & 04 & $\begin{array}{l}- \\
100 \%\end{array}$ \\
\hline EPI & $\begin{array}{l}\text { Usa freqüentemente } \\
\text { Não usa freqüentemente }\end{array}$ & $\begin{array}{l}03 \\
01\end{array}$ & $\begin{array}{l}75 \% \\
25 \%\end{array}$ \\
\hline EPI & $\begin{array}{l}\text { São confortáveis } \\
\text { Não }\end{array}$ & $\begin{array}{l}03 \\
01\end{array}$ & $\begin{array}{l}75 \% \\
25 \%\end{array}$ \\
\hline
\end{tabular}

Tabela 3 - Respostas dos profissionais de enfermagem na UBS em relação aos materiais utilizados para executar as tarefas. Volta Redonda/RJ, 2005. 
A maioria $(90 \%)$ das profissionais assinala que os materiais utilizados na execução das tarefas são inadequados em sua qualidade, especificando as luvas, esparadrapos e o aparelho de pressão. Em sua quantidade, os materiais são reconhecidos por todas como inadequados, pois faltam EPI, pomadas, luvas, ataduras, medicamentos, gases. Ressaltam que em alguns períodos a falta destes materiais é maior.

Os EPI são usados por $90 \%$ das trabalhadoras de enfermagem, mas foi relatado pela maioria que os óculos utilizados durante a execução da vacina BCG é único, sendo utilizado por todas, e entendido por elas como um equipamento de proteção coletiva e não individual. Consideram os EPI confortáveis, porém uma das respondentes ressaltou que os óculos a deixam com as "vistas embaçadas".

Os EPIS utilizados na UBS são as luvas nos diversos procedimentos realizados pela enfermagem e os óculos usados especificamente durante o procedimento de vacinação BCG. 


\section{Ambiente de trabalho}

A seguir apresentam-se e discutem-se as respostas dos profissionais de enfermagem em relação à adequação do ambiente de trabalho.

\begin{tabular}{|c|c|c|c|}
\hline \multirow[t]{2}{*}{ Indicadores } & \multirow[t]{2}{*}{ Respostas } & \multicolumn{2}{|c|}{ Prof. de Enf } \\
\hline & & f & $\%$ \\
\hline Risco ambiental & $\begin{array}{l}\text { Sim } \\
\text { Não }\end{array}$ & $\begin{array}{l}02 \\
02\end{array}$ & $\begin{array}{l}50 \% \\
50 \%\end{array}$ \\
\hline Espaço físico & $\begin{array}{l}\text { Permite conforto } \\
\text { Não permite }\end{array}$ & $\begin{array}{l}01 \\
03\end{array}$ & $\begin{array}{l}25 \% \\
75 \%\end{array}$ \\
\hline Ambiente de trabalho & $\begin{array}{l}\text { Adequado } \\
\text { Não adequado }\end{array}$ & $\begin{array}{l}03 \\
01\end{array}$ & $\begin{array}{l}75 \% \\
25 \%\end{array}$ \\
\hline $\begin{array}{l}\text { Disposição dos } \\
\text { equipamentos }\end{array}$ & $\begin{array}{l}\text { Adequada } \\
\text { Não adequada }\end{array}$ & 04 & $100 \%$ \\
\hline Temperatura & $\begin{array}{l}\text { Adequada } \\
\text { Não adequada }\end{array}$ & $\begin{array}{l}02 \\
02\end{array}$ & $\begin{array}{l}50 \% \\
50 \%\end{array}$ \\
\hline Iluminação & $\begin{array}{l}\text { Adequada } \\
\text { Não adequada }\end{array}$ & $\begin{array}{l}03 \\
01\end{array}$ & $\begin{array}{l}75 \% \\
25 \%\end{array}$ \\
\hline
\end{tabular}

Tabela 4 - Respostas dos profissionais de enfermagem na UBS em relação à adequação do ambiente de trabalho. Volta Redonda/RJ, 2005.

Ao analisar a situação de trabalho na UBS quanto ao ambiente de trabalho, verificou-se que as trabalhadoras consideram o ambiente adequado (90\%). Mas ao detalhar esta concepção, percebeu-se que estas profissionais $(90 \%)$ reconhecem que o espaço físico não lhes permite conforto. Este fato é atribuído à falta de 
privacidade durante o horário de almoço; aos espaços mal distribuídos; à localização das salas de consultas, de vacinas, curativa e nebulização anterior à recepção; à falta de lugar para o descanso no setor e à falta de vestiário próprio para guardar seus pertences.

Estas situações apontadas pelas profissionais expõem-nas aos riscos de violência verbal em relação ao espaço muito próximo das salas de procedimentos com a sala de espera, na qual estão os usuários. De outra forma, o espaço físico deve proporcionar conforto aos trabalhadores, como preconiza a NR-17 (condições ergonômicas), para promover o bem-estar e a saúde dos mesmos. Esta situação merece a atenção da administração e foi foco da ergonomia neste estudo.

Mauro et al. (2004, p. 340), ao abordarem sobre os riscos ocupacionais em saúde, chamaram a atenção para os fatores de riscos mais comuns, entre eles monotonia, o meio físico inadequado, as instalações sanitárias insuficientes, a falta de salas de descanso e assentos; a saúde e higiene mental insatisfatórias e a fadiga. Desse modo, o ambiente de trabalho pode converter-se em elemento agressor do indivíduo.

Os mesmos autores ressaltaram que a fórmula ideal para a vida humana consiste em manter em equilíbrio os componentes biológicos e psíquicos da personalidade e os fatores sociais e do ambiente (MAURO et al., 2004, p. 340).

A falta de privacidade também é preocupante. Observou-se a interrupção dos funcionários, até mesmo durante a realização das atividades. $\mathrm{O}$ acesso aos profissionais é fácil. Os usuários, às vezes, buscam os trabalhadores para solucionarem seus problemas, em momentos em que o profissional realiza 
procedimento que exigia grande atenção. Por exemplo, a imunização, em que é necessária a redobrada atenção para evitar a ocorrência de erros quanto à vacina a ser administrada, dose, via de administração, tamanho da agulha, dentre outros aspectos.

Sobre a temperatura e a iluminação, foi revelado pelas depoentes que falta refrigeração, uma vez que não é permitido o ar condicionado. Especificamente na sala de vacinação, há insulfilme nas janelas, o que prejudica a realização da BCG. Citam também que às vezes falta manutenção quanto à iluminação.

\section{Organização do trabalho}

Na organização do trabalho, conforme a Tabela 5, a carga horária semanal das profissionais de enfermagem é de oito horas diárias, totalizando quarenta horas semanais. As pausas foram consideradas adequadas (90\%) e relacionavam-se ao horário de pausa para o almoço, sendo que uma das depoentes reconheceu que não há pausa durante a jornada de trabalho. 


\begin{tabular}{|l|l|cc|}
\hline \multicolumn{1}{|c|}{ Indicadores } & \multicolumn{1}{|c|}{ Respostas } & Prof. de Enf \\
& & f $\%$ \\
\hline Carga horária diária & 8 horas & 04 & $100 \%$ \\
\hline Esquema fixo de horário & Adequado & 03 & $75 \%$ \\
& Não Adequado & 01 & $25 \%$ \\
\hline Esquema de pausa & Adequado & 03 & $75 \%$ \\
\hline Falta ao trabalho & Não Adequado (não existe) & 01 & $25 \%$ \\
\hline Supervisão & Sim & 01 & $25 \%$ \\
& Não & 03 & $75 \%$ \\
\hline Dificuldade em trabalhar & Sim & 03 & $75 \%$ \\
\hline & Não Adequada & 01 & $25 \%$ \\
\hline & Não & 03 & $75 \%$ \\
\hline
\end{tabular}

Tabela 5 - Respostas dos profissionais de enfermagem na UBS em relação à organização do trabalho. Volta Redonda/RJ, 2005.

As faltas ao trabalho são por motivos de doenças, especificamente os quadros patológicos de hipertensão, descritos anteriormente, do qual duas profissionais são acometidas.

A supervisão do trabalho na unidade é considerada adequada pela equipe de enfermagem (90\%); vale destacar que uma das respondentes relata ser inadequada, porque muitas vezes a gerente não tem respaldo administrativo para melhor desenvolver o seu trabalho.

Alves; Penna; Brito (2004, p. 441) apontam que os gerentes dos serviços 
locais de saúde vêm assumindo responsabilidades, seja com a clientela, seja com a administração central e com a equipe de trabalho. Tratando-se de unidades básicas de saúde, os gerentes, na busca de respostas às demandas, passam a ser articuladores por excelência, tanto no âmbito interno como externo às unidades de saúde, necessitando de capacitação específica e que nem sempre é realizada, repercutindo no processo de trabalho.

Também se reconhece que o gerenciamento de uma Unidade Básica de Saúde, na busca de resolutividade, supera a dimensão dos conhecimentos e atributos pessoais, sendo necessário que o município assuma seu compromisso na capacitação de seus gerentes, respaldando-os com conhecimentos necessários para responder às exigências da política de saúde (ALVES; PENNA; BRITO, 2004, p. 446).

A maioria das trabalhadoras de enfermagem $(90 \%)$ reconhece que o problema maior é o quantitativo de funcionários em relação ao volume de atendimentos.

Existem contradições no que se refere ao fato de considerarem a organização do trabalho boa, embora ressaltem a escassez de pessoal, o que não condiz com o absenteísmo e a situação de necessidades sistemáticas de substituição de pessoal em outras unidades de saúde ou mesmo na própria UBS.

Assim, faz-se importante citar os determinantes da situação de trabalho de acordo o relato das trabalhadoras de enfermagem, na UBS estudada. As suas participações, como sujeitos diretos do processo de trabalho, são de grande relevância em análises ergonômicas do trabalho. Os fatos evidenciados foram agrupados de acordo com os fatores de risco associados, apresentados a seguir. 
Fatores Biológicos: acidente de trabalho com conteúdo de vacina atingindo os olhos;

Fatores Físicos: falta de refrigeração nos ambientes e falta de manutenção quanto à iluminação;

Fatores Psicossociais: insuficiente número de trabalhadores de enfermagem, baixos salários, sobrecarga de trabalho, adoecimento do profissional, efetivação das trabalhadoras de nível técnico como auxiliares de enfermagem, falta de treinamento da equipe (atualização), realidade de vida e trabalho das trabalhadoras que dificulta manter um segundo emprego para melhor renda familiar, insatisfação pela falta de condições de trabalho (materiais e número de pessoal), estresse por muito tempo de serviço e por trocas constantes para outras UBS, exigência dos usuários que querem respostas imediatas e atendimento eficaz, a agressão verbal ocorre de forma constante pelos usuários para com as profissionais da unidade (xingamentos e expressões verbais agressivas), queixas de maus tratos e atos de violências verbais por parte dos usuários, profissionais de enfermagem (50\%) fazem uso do fumo;

Fatores Ergonômicos: faltam óculos de proteção para todos; 50 \% das trabalhadoras estão com sobre peso e $25 \%$ obesas; a quantidade de atendimento é elevada provoca cansaço sempre que a sala de espera fica superlotada e com muita "falação", as tarefas foram consideradas excessivas (50\%) em cada jornada de trabalho com muitos deslocamentos durante as tarefas, materiais são inadequados em sua qualidade (luvas, esparadrapos e 
o aparelho de pressão) e quantidade (EPI, pomadas, luvas, ataduras, medicamentos, gases), os óculos de proteção deixam os olhos embaçados, os espaços físicos não lhes permitem conforto e são mal distribuídos (falta de privacidade - salas próximas à recepção)

Outros fatores (Organizacionais): alto índice de saída das trabalhadoras para outras unidades do Distrito para substituir eventuais faltas e/ou licenças de outros profissionais de enfermagem em outras unidades do mesmo Distrito, horário de alimentação é irregular (cotidianamente o horário não é respeitado, passando do horário normal, em função do trabalho), há falta de segurança na unidade.

Percebe-se, então, que a atuação ergonômica está em todos os casos, orientada ao ajuste entre as exigências das tarefas e as necessidades e possibilidades das pessoas em relação às dimensões físicas, psicológicas e organizacionais do trabalho (VELAZQUEZ et al., 1995, p. 17)

Para atuar em ergonomia, é conveniente um programa que contemple não somente os aspectos técnicos e metodológicos, mas, sim, que também defina as condições favoráveis na organização e nos aspectos determinantes (VELAZQUEZ et al., 1995, p. 18).

Evidenciaram-se nos profissionais de enfermagem da UBS características antropométricas, de sua saúde e trabalho, as quais permitiram conhecer os determinantes que dificultam o seu trabalho, interferindo de forma negativa na satisfação e desempenho de suas ações. Portanto, como importantes indicativos de má adaptação ao trabalho e violência ocupacional. 


\subsection{Os postos de trabalho}

Em continuidade à discussão, cabe a descrição dos postos de trabalho. A planta física da Unidade de Saúde (Figura 6) permite uma melhor visualização.

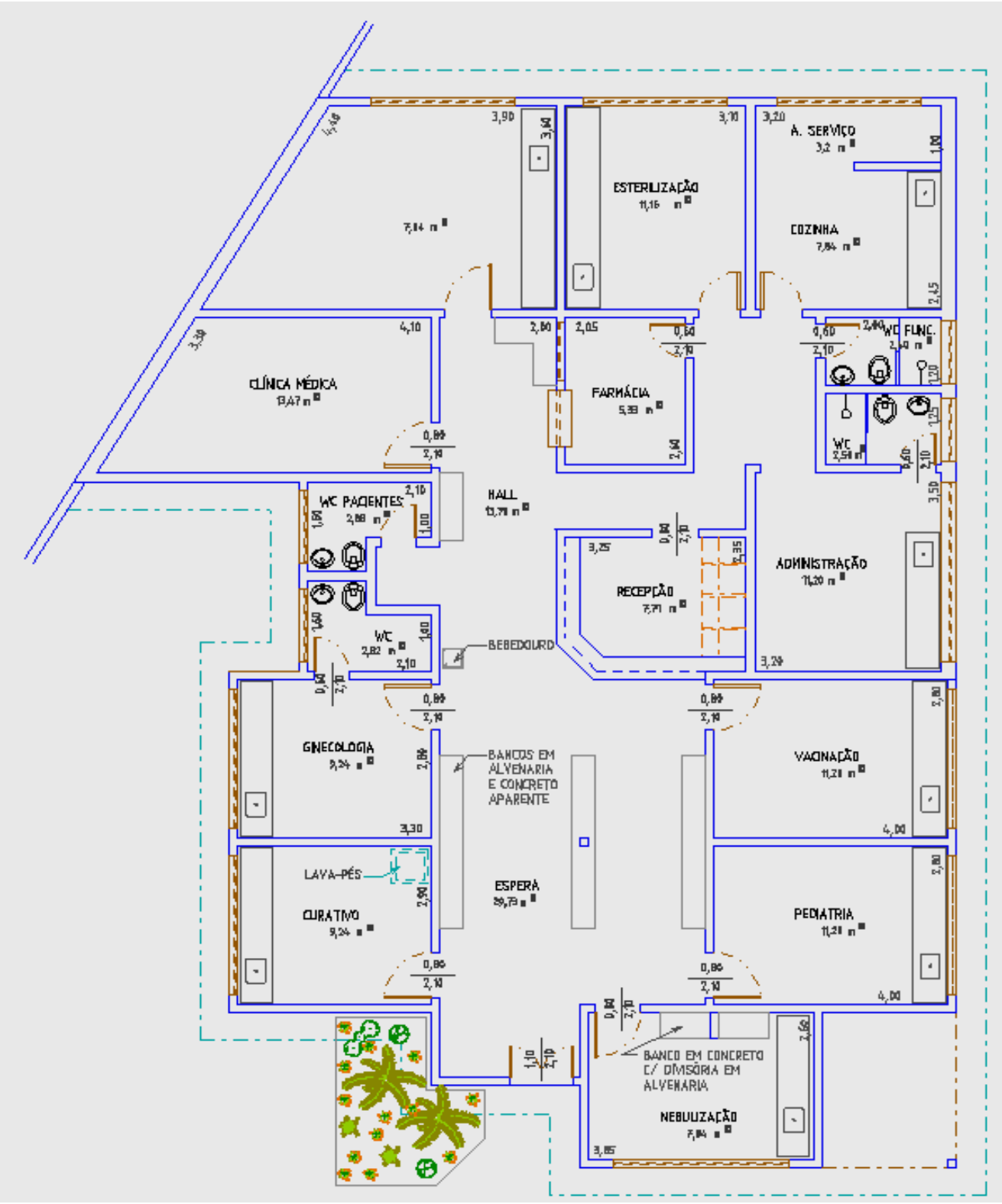

Figura 6- Planta Física da Unidade Básica de Saúde. Volta Redonda, 2005

Fonte: SMS/VR

Os postos de trabalho da enfermagem, representados por salas, possuem pé 
direito (altura) 2,98 m, comprimento $3,92 \mathrm{~m}$ e largura $2,82 \mathrm{~m}$, telhado tipo simétrico com cobertura em laje. A estrutura é em concreto, com paredes em alvenaria com revestimento em azulejo ate $1,55 \mathrm{~m}$ do piso, com janela basculante de madeira e vidro $0,80 \times 1,15$ a $1,80 \mathrm{~m}$ do piso e porta de madeira $2,10 \times 0,70 \mathrm{~m}$. O piso é de cerâmica.

\section{Sala de ginecologia}

Mobiliário

A sala possui uma bancada/pia constituída em alvenaria e com acabamento em azulejo e portas de alumínio com acrílico. As medidas da pia são: altura $83 \mathrm{~cm}$ e largura $51 \mathrm{~cm}$; a medida da mesa é de 91 x $81 \times 56 \mathrm{~cm}$. Há cadeiras cujas medidas eram altura do encosto $25 \mathrm{~cm}$; assento 40 de largura $\mathrm{x} 39 \mathrm{~cm}$ de profundidade, altura do assento 44 . Tem uma maca com altura de $85 \mathrm{~cm}$. Também existe uma balança mecânica e um armário a $96 \mathrm{~cm}$ do piso.

As recomendações ergonômicas para dimensionamento dos locais de trabalho são fundamentadas nas medidas antropométricas dos trabalhadores no modo de ação dos mesmos e nas exigências específicas do trabalho. 


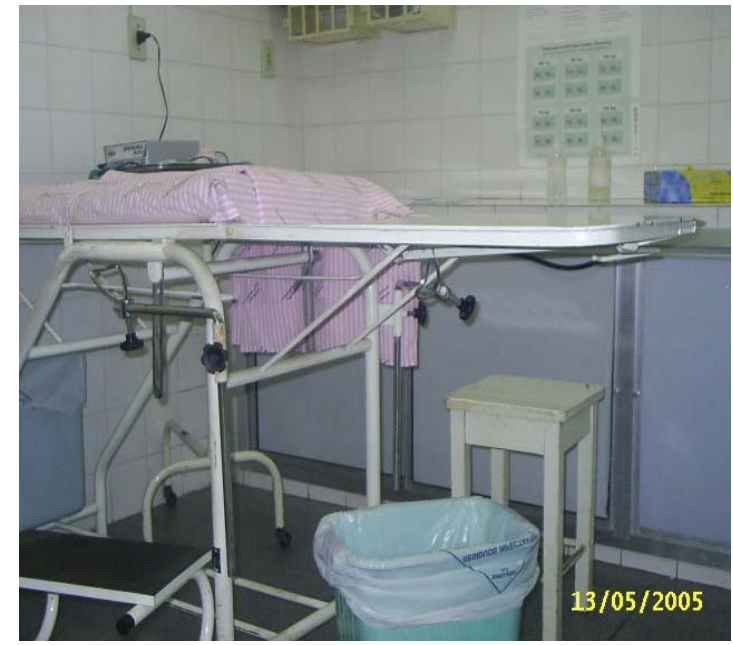

Figura 7 - Sala de ginecologia

Apresentadas anteriormente as medidas antropométricas das trabalhadoras de enfermagem, recomendou-se a altura de bancadas entre $82,4 \mathrm{~cm}$ e $92,4 \mathrm{~cm}$. Observou-se, então, que a bancada da pia atende a esta especificação. A altura da maca deve ser regulável, o que está subsidiado por Alexandre; Moraes (1998, p. 636), argumentando orientações ergonômicas específicas para as atividades desenvolvidas pela equipe de enfermagem.

De acordo com Grandjean (1998, p. 70), os assentos de uma cadeira para todos os tipos de atividades devem ser adequados. O encosto deve ter altura de 48 a $52 \mathrm{~cm}$ do assento (na perpendicular). $\mathrm{O}$ assento deve ter 40 a $45 \mathrm{~cm}$ de largura e 38 a $42 \mathrm{~cm}$ de profundidade, graduação de altura entre 38 a $54 \mathrm{~cm}$. A cadeira deve oferecer apoio para os pés com angulação entre 10 a 25 graus. 


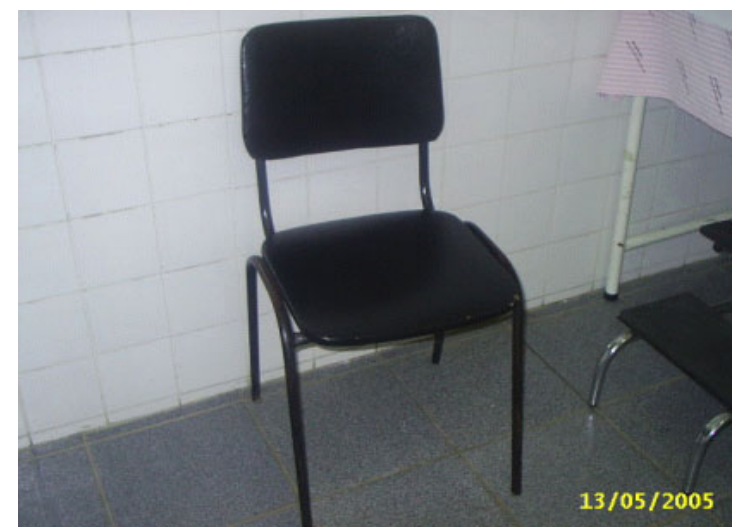

Figura 8 - Cadeira não planejada, segundo as recomendações ergonômicas

Verifica-se que as medidas da cadeira da sala de ginecologia não estão adequadas na altura do encosto, o qual deve proporcionar conforto, especialmente à coluna vertebral. Sendo assim, é indicada intervenção ergonômica por meio de recomendações.

Nesta sala, a mesa é usada para consulta médica e não foi objeto deste estudo.

No pré-atendimento, existe atuação da equipe de enfermagem. As ações desenvolvidas eram de cuidados à mulher, à gestante, puérpera ou nutriz, visando manter o estado de saúde satisfatório nestes diferentes períodos de vida. Nesse setor, os técnicos e auxiliares de enfermagem realizam o preparo da clientela que compreende pesar, medir, verificar a pressão arterial e acompanhavam a consulta médica ginecológica (coleta em exame preventivo) e de pré-natal.

Há riscos ambientais biológicos, principalmente nos procedimentos dos exames ginecológicos e riscos ergonômicos: exigência de postura inadequada em relação ao assento. 


\section{Sala de nebulização e outros procedimentos}

Como mobiliários, a sala tem uma bancada/pia constituída em alvenaria e com acabamento em azulejo e portas de alumínio com acrílico.As medidas desta são: altura $83 \mathrm{~cm}$ e largura $51 \mathrm{~cm}$. Há um banco de alvenaria, cuja altura é de $42 \mathrm{~cm}$ e largura $40 \mathrm{~cm}$. Tem uma mesa com medida de $56 \mathrm{~cm}$. Tem duas cadeiras, cujas medidas eram: altura encosto $25 \mathrm{~cm}$ altura do assento $44 \mathrm{~cm}$ e assento $40 \times 39$ cm. Possui uma maca com altura de $0,68 \mathrm{~m}$. Há também um ventilador portátil, um apoio para o braço e um suporte para soro.

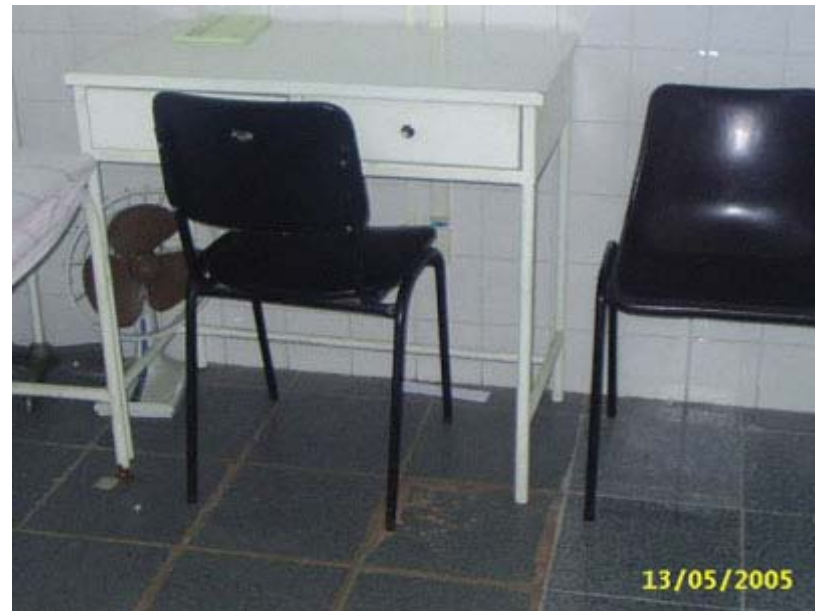

Figura 9 - Cadeira e mesa não planejadas segundo as recomendações ergonômicas, induzindo à má postura corporal pelos trabalhadores

A mesa é utilizada constantemente pela equipe de enfermagem. Para Iida (1990, p. 138), a altura recomendada deste móvel é de $74 \mathrm{~cm}$ de altura. Assim, a sua altura na sala de nebulização está abaixo do recomendado em $18 \mathrm{~cm}$, 
evidenciando sua inadequação.

Em relação ao dimensionamento da bancada e cadeira, observaram-se as mesmas condições ergonômicas descritas anteriormente.

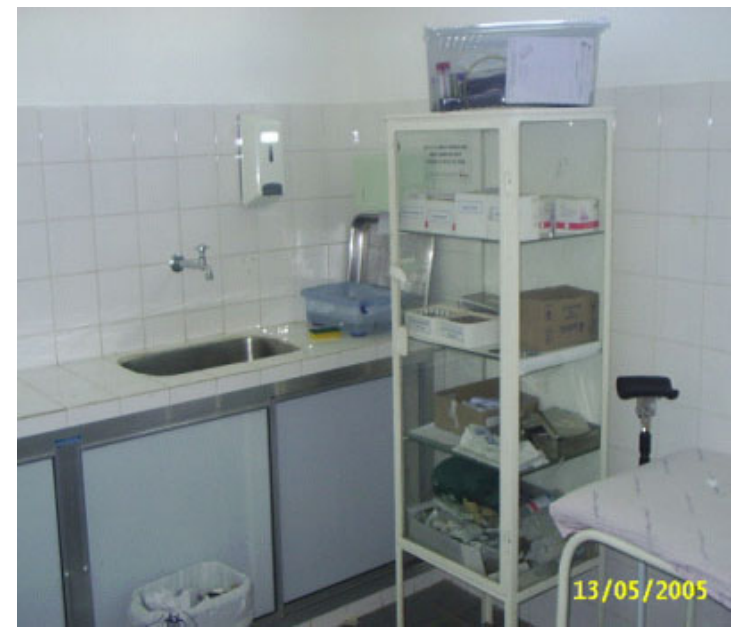

Figura 10 - Visão da sala de nebulização em relação à bancada de pia e outros equipamentos

Nesta sala atuam técnico e auxiliares de enfermagem que se revezam na execução de procedimentos de nebulização, teste do pezinho, aplicação de medicações injetáveis, aferição de pressão arterial, coleta de material para exames laboratoriais, orientações, medicação supervisionada.

Os riscos ambientais existentes são os biológicos (contato com afecções respiratórias dos usuários e outros), físicos (fio elétrico de aparelho nebulizador, conforme figura 17) químicos (administração de medicamentos, entre eles, para tuberculose e hanseníase) e ergonômicos (exigência de postura inadequada e ritmo intenso de trabalho). Os EPI utilizados eram as luvas descartáveis.

Elucidando a questão, Marziale (1995, p. 15) aponta que a própria 
administração de medicamentos pode ocasionar riscos de sensibilização alérgica (antibióticos); a freqüente lavagem das mãos pode favorecer a ocorrência de eczemas e a exposição aos gases e esterilizantes pode gerar irritação das mucosas e reações alérgicas. Afirma ainda que o trabalhador de enfermagem pode estar mais ou menos em contato com agentes químicos, de acordo com o tipo de produto que manipula ou a que se expõe, com o tempo de exposição e com a concentração do produto.

\section{Sala de curativos}

A sala tem uma bancada/pia constituída em alvenaria e com acabamento em azulejo e portas de alumínio com acrílico. Medidas da Pia altura $83 \mathrm{~cm} \mathrm{e}$ largura $0,51 \mathrm{~m}$. Tem uma maca com altura de $85 \mathrm{~cm}$. Tem um armário de ferro e vidro para medicamentos, cuja medida é 1,66 x 0,69 x $0,40 \mathrm{~m}$. Tem um carrinho de curativo em aço inox, com medida de 0,81 x 0,76 x $0,44 \mathrm{~m}$.

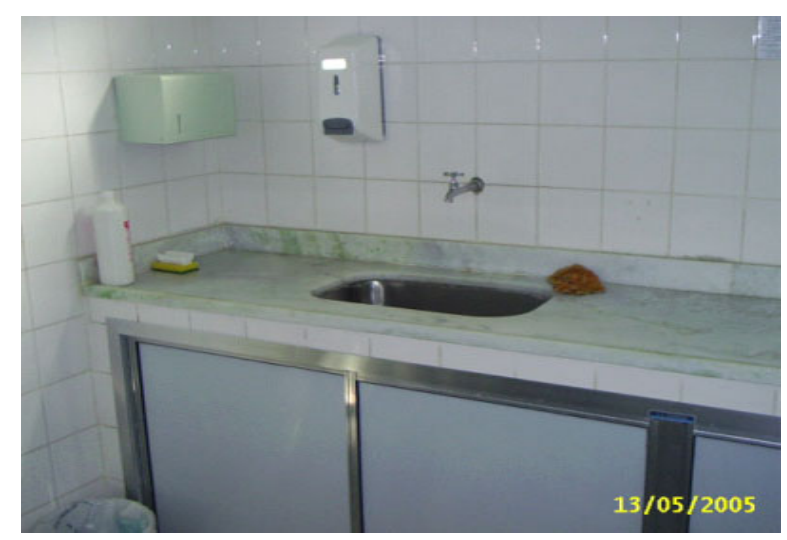

Figura 11 - Bancada de pia na sala de curativos 
As medidas do carrinho de curativos encontram-se inadequadas. A adoção de posturas incorretas foi observada na realização de curativo, em que de pé a profissional permanecia por tempo prolongado com a coluna inclinada, para adequar-se aos cuidados prestados (curativo) nos pés de uma criança que se acidentou. A figura 19, a seguir, representa o espaço em que o profissional de enfermagem tem para atuar durante o procedimento citado.

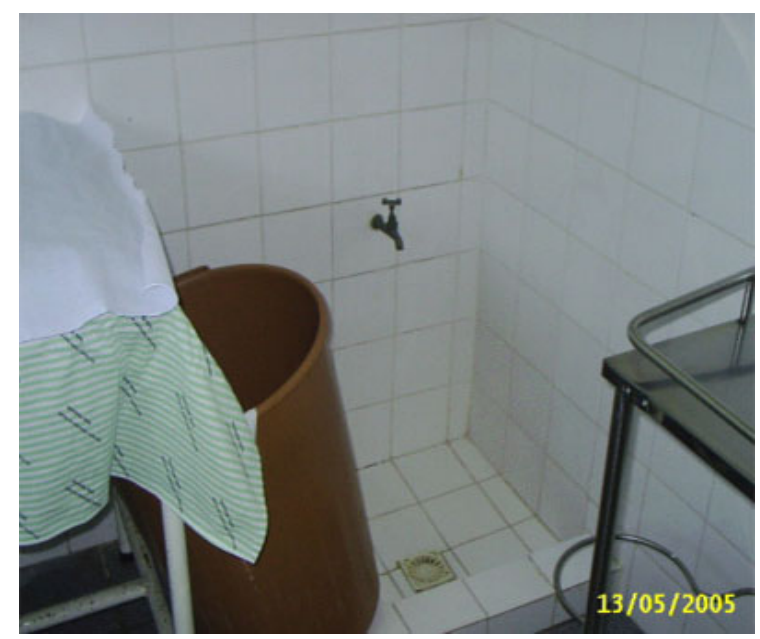

Figura 12 - Espaço para atividade de curativo

$\mathrm{O}$ setor atende aos primeiros socorros e a equipe realiza curativos em crianças, adolescentes, adultos e idosos.

Os riscos ambientais potenciais na sala são os biológicos, químicos (uso de soluções antissépticas e medicações tópicas) e ergonômicos. Os profissionais fazem uso de luvas descartáveis individuais como EPI, nos procedimentos efetuados. 


\section{Sala de vacinação}

Como mobiliários esta sala possui uma bancada/pia constituída em alvenaria e com acabamento em azulejo e portas de alumínio com acrílico, sendo que as medidas da pia eram: altura $83 \mathrm{~cm}$ e largura $51 \mathrm{~cm}$. Possui uma mesa, cuja medida é de $56 \mathrm{~cm}$. Tem três cadeiras, com as medidas: altura do encosto, $0,25 \mathrm{~m}$, altura do assento, 0,44 $\mathrm{m}$, e do assento, 0,40x0,39 m. Tem uma maca com altura de 0,68m. Além disso, há um ventilador de teto, uma balança e um refrigerador vertical (rede de frio).

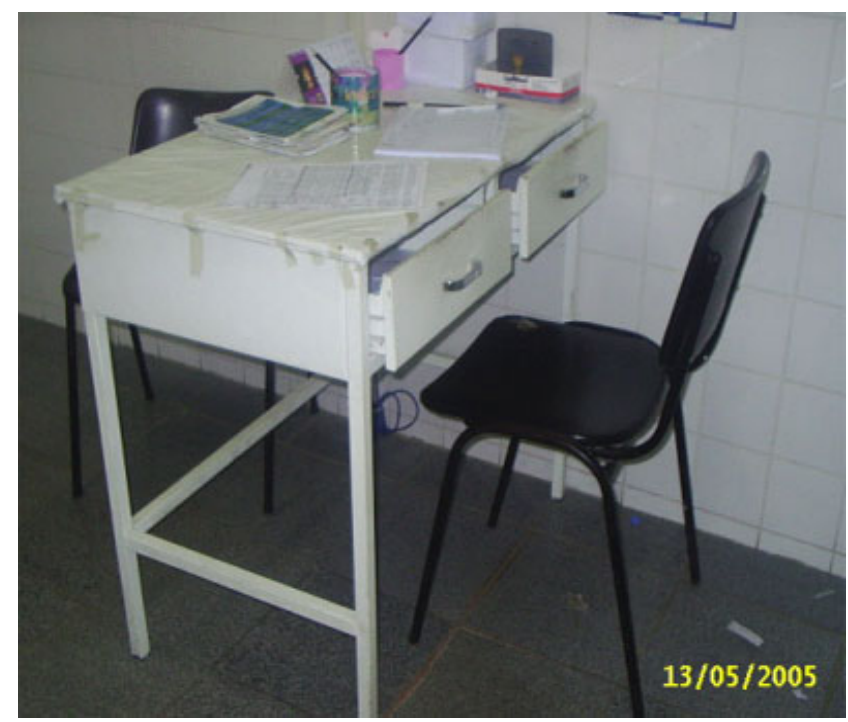

Figura 13 - Inadequação quanto às recomendações ergonômicas da mesa e cadeira

A inadequação da mesa e do encosto da cadeira estão presentes, considerando as suas medidas. O desconforto que provocava é fator determinante das condições de trabalho, que favorecem as dores na coluna vertebral e cansaço referidos pela equipe. A sala de vacinação, em especial, necessita das 
recomendações ergonômicas que serão apresentadas no próximo capítulo.

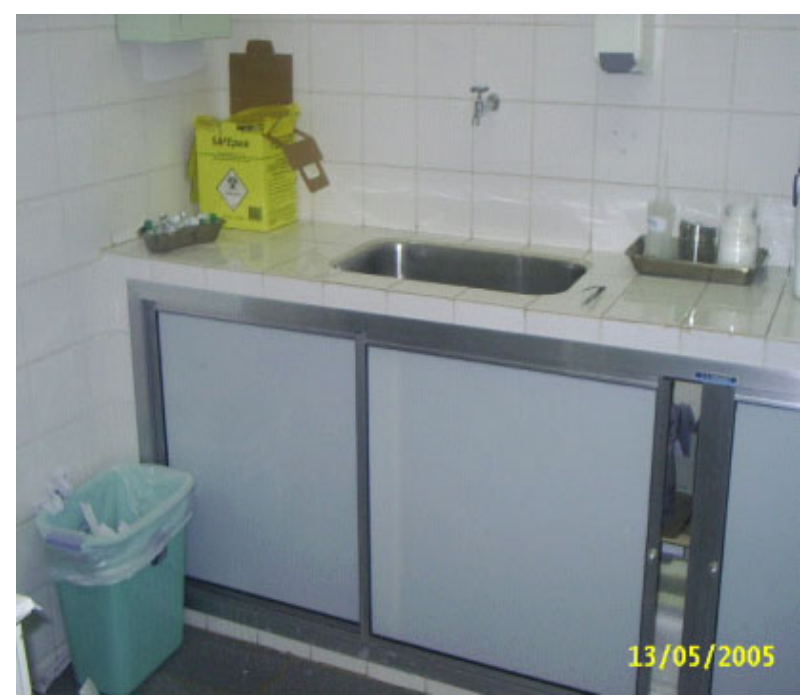

Figura 14 - Acondicionamento do lixo da sala de vacinação

Os riscos detectados no ambiente são os biológicos e os ergonômicos provenientes da aplicação de imunobiológicos, deslocamentos freqüentes da equipe de enfermagem, permanência na posição em pé por mais tempo, entre outros. O lixo em sala de vacinação, conforme preconizado pelo Ministério da Saúde (ROCHA, 2001, p. 60) exige cuidados próprios, por ser caracterizado como lixo perigoso (material biológico e resíduos perfurocortantes) e lixo comum. É recomendado seu acondicionamento em recipientes de material resistentes (descarpack), para o descarte de resíduos perfurocortantes, em saco plástico de cor branco-leitosa o material biológico e os demais resíduos sólidos, semi-sólidos ou comuns em sacos plásticos de cor azul ou verde. Estes cuidados são normas de 
biossegurança em relação aos trabalhadores de enfermagem e os da limpeza, visando à prevenção de doenças e acidentes. Verificou-se que não existe separação para o lixo comum.

A equipe de enfermagem, na sala de vacinação, atua na aplicação de imunobiológicos. Há contato com produtos químicos para antissepsia das mãos. Atua, ainda, em agendamento, conservação das vacinas, registro das fichas, estatística diária, triagem e orientações.

Em seus estudos Farias (2004, p. 88), verificou que, na unidade de saúde que pesquisou, o profisssional auxiliar de enfermagem fazia a limpeza e a esterilização do instrumental utilizado na odontologia; aplicação de imunobiológicos e medicação em geral por via parenteral na sala de vacinas, o contato com a medicação supervisionada no setor-tuberculose e hanseníase; a utilização de sabões e o emprego de luvas descartáveis nos contatos. Existia o manuseio de várias substâncias químicas.

A exposição a esses riscos merece atenção, uma vez que necessitam de treinamento próprio para sua prevenção e implantação de uma cultura de segurança no trabalho que envolva todos os participantes da organização do serviço.

\section{Sala de esterilização}

O mobiliário é composto de uma bancada/pia constituída em alvenaria e com acabamento em azulejo e portas de alumínio com acrílico, cujas medidas eram: altura $83 \mathrm{~cm}$ e largura $51 \mathrm{~cm}$. Há uma mesa que mede $56 \mathrm{~cm}$, duas cadeiras com altura de encosto de $0,25 \mathrm{~m}$, altura do assento de $0,44 \mathrm{~m}$. Tem uma cadeira giratória com altura de $0,55 \mathrm{~m}$ e assento $0,43 \times 0,4$. Há uma maca com de $68 \mathrm{~cm} \mathrm{e}$ 
uma autoclave.

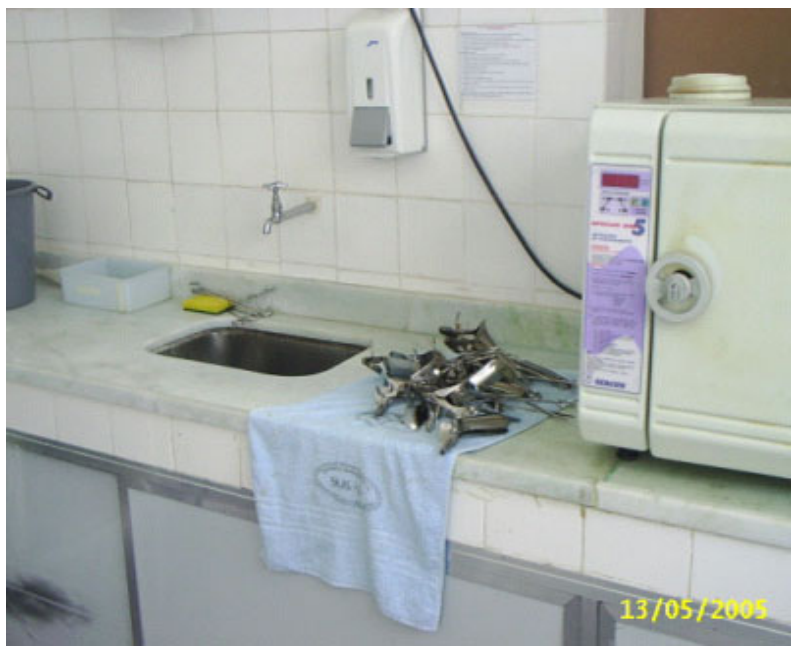

Figura 15 - Preparo do material em sala de esterilização

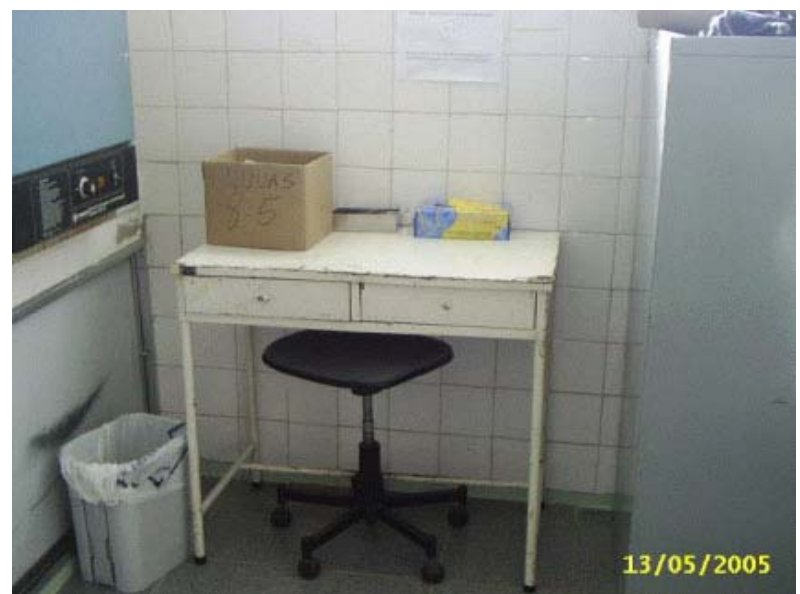

Figura 16 - Mesa e cadeira em condições não recomendadas em ergonomia

Os riscos ambientais potenciais são os físicos, biológicos e ergonômicos representados pela cadeira com encosto quebrado e em condições inseguras, conforme figura a seguir, presença de microorganismos durante a limpeza e 
preparo de material para esterilização e posições ergonômicas inadequadas adotadas durante as tarefas, como o não descanso à coluna vertebral, entre outros.

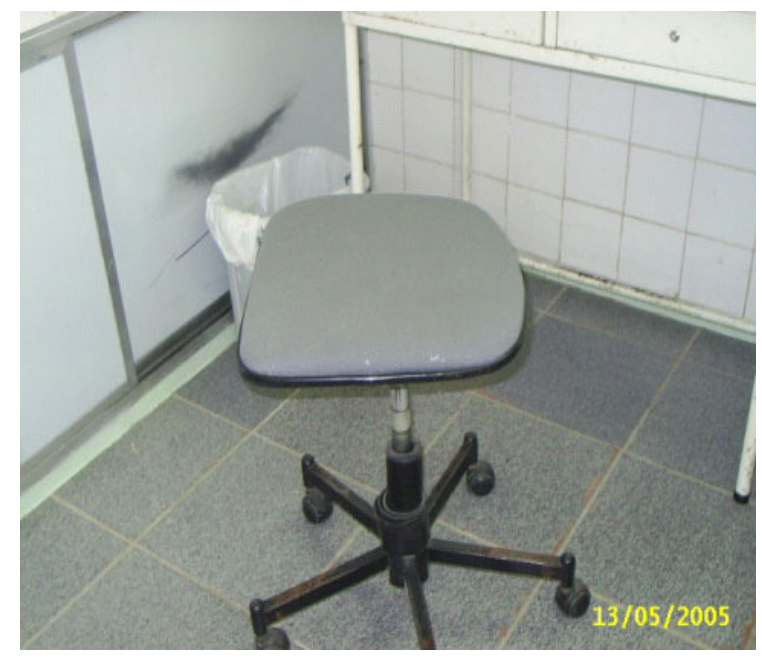

Figura 17 - Cadeira sem encosto e em condições inseguras para o uso

Destinada ao preparo e esterilização do material da UBS. Nela, a equipe lava, empacota e esteriliza o material utilizado nos procedimentos durante cada jornada de trabalho, entre eles, espéculos, pinças e gazes.

\section{Farmácia}

Possui pé direito (altura) de 2,98 m, comprimento de 2,61 $\mathrm{m}$ e largura de 2,00m, com telhado simétrico, cobertura em laje e estrutura em concreto. As paredes são em alvenaria, com janela basculante de madeira e vidro $(0,90 \times 0,70 \mathrm{a}$ $1,70 \mathrm{~m}$ do piso) e uma abertura na janela tipo guichê medindo 1,00 x 0,70 a $0,97 \mathrm{~m}$ do piso com porta de madeira medindo 2,10x0, 70 m. Piso em cerâmica. 
O mobiliário é constituído de prateleiras de madeira do piso com espaçamento de $0,40 \mathrm{~m}$.

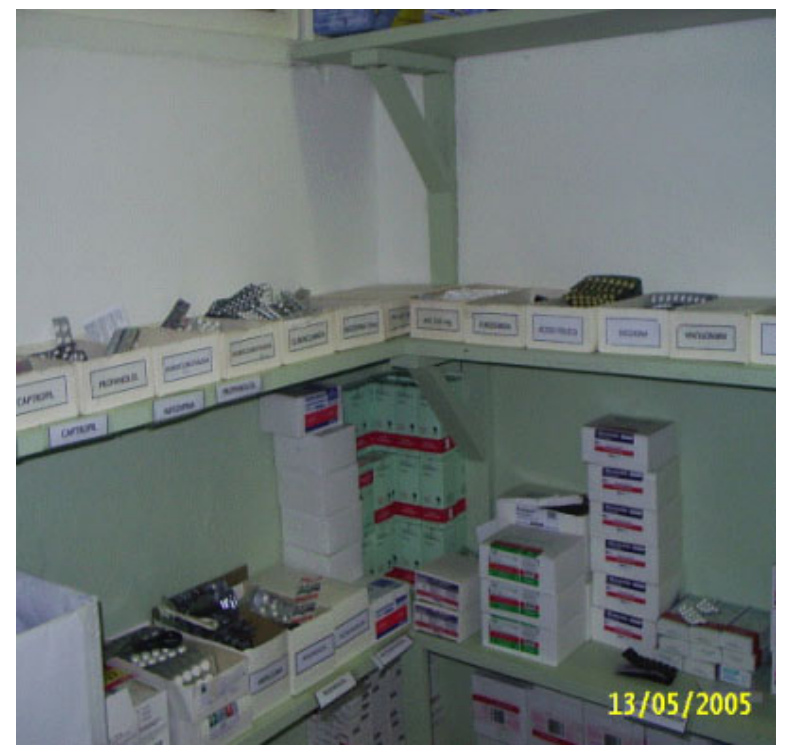

Figura 18 - Sala de distribuição de medicamentos

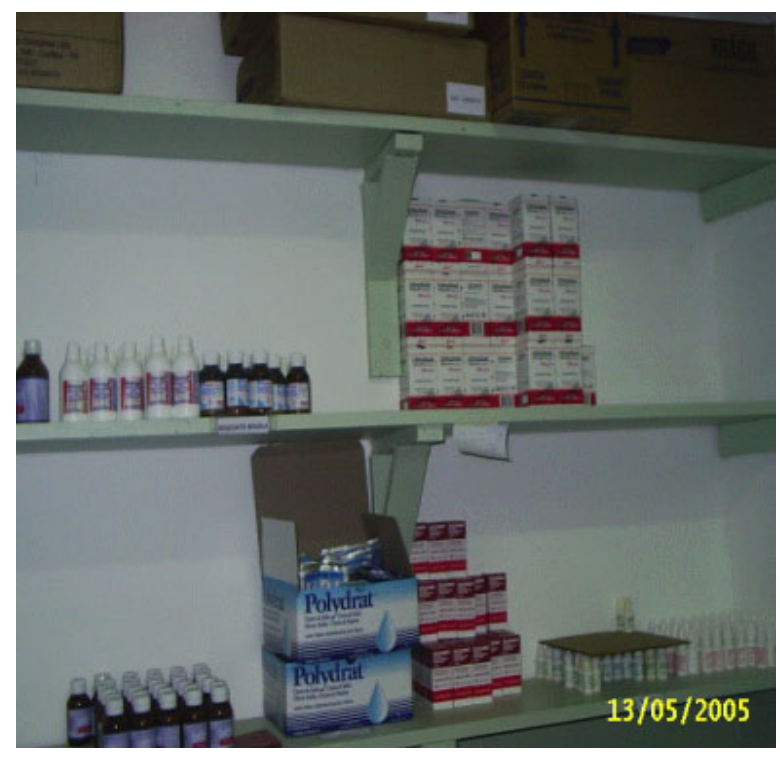

Figura 19 - Prateleiras e altura inadequadas

Há riscos ambientais potenciais do tipo químicos, de acidentes de trabalho, 
físicos e ergonômicos especificados pelos produtos farmacêuticos, prateleiras com cinco divisórias, sendo que a última prateleira encontrava-se a $2 \mathrm{~m}$ de altura do piso. Assim, exigia o uso de escada para utilizá-la. A atividade é executada com exigência de postura inadequada, como períodos na posição em pé durante a distribuição de medicamentos e ritmos intensos de idas e vindas entre os postos de trabalho e este.

Alexandre (1998 a, p. 84), em estudo sobre ergonomia e as atividades ocupacionais da equipe de enfermagem, menciona sobre a manutenção de posturas inadequadas que ocasionam tensão física, afetando a musculatura e constituição ósseo-articular, principalmente da coluna vertebral e membros.

A mesma autora (p. 103) considera de primordial importância que seja difundido entre os trabalhadores de enfermagem aspectos ergonômicos de segurança no trabalho, para incentivar a consciência crítica sobre os efeitos do ambiente do trabalho sobre a saúde. 


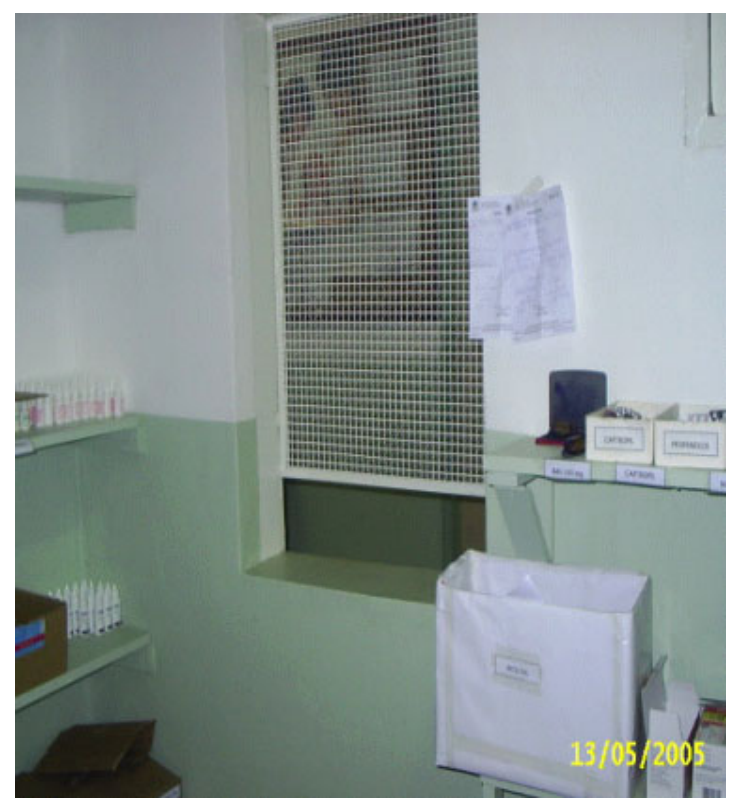

Figura 20 - Janela para distribuição de medicamentos

Neste setor, os profissionais de enfermagem distribuíam medicamentos à comunidade do Bairro, conforme receituário apresentado a eles, com orientações e verificações da receita. Esta atividade era feita na posição de pé durante todo o dia, à medida que era solicitada pela clientela. A altura da bancada na janela para $\mathrm{o}$ atendimento $(97 \mathrm{~cm})$ estava acima da recomendada pelas especificações ergonômicas em relação às medidas antropométricas das trabalhadoras

Grandjean (1998, p. 46) ressalta que o trabalho em pé provoca o emprego de uma relativa força e utiliza-se da ajuda do peso do tronco. Assim, a ergonomia contribui para o esclarecimento e entendimento das influências de comportamentos e posturas adotados no trabalho.

Os principais problemas encontrados são de natureza ergonômica, 
constando-se a inadequação dos mobiliários em relação às características do trabalho de enfermagem e dos trabalhadores. Esta situação torna o trabalho mais árduo produzindo cansaço, estresse e desconforto. Constitui fator de risco para os problemas de saúde apresentados pelas trabalhadoras.

A aquisição de equipamentos dentro de uma abordagem ergonômica deve ser planejada, nesta situação recomenda-se escadinha de dois degraus, favorecendo as atividades da equipe de enfermagem (ALEXANDRE; ROGANTE, 2001, p. 81). Uma forma de minimizar os efeitos adversos de posturas incorretas para as estruturas músculo-esqueléticas é o planejamento e ou replanejamento do ambiente físico, com adoção de mobiliário ajustável a diferentes requisitos da tarefa e às medidas antropométricas individuais (ZAPATER et al., 2004, p. 191). Esta afirmativa é a recomendação ergonômica mais indicada. 


\section{$5.4 \mathrm{O}$ ambiente e os agentes físicos}

Para análise deste componente da situação de trabalho efetuou-se a aferição dos agentes físicos: temperatura, iluminação e ruído em todas os postos de trabalho em que atuavam as trabalhadoras de enfermagem.

\section{Temperatura}

Aferição da Temperatura: condições climáticas do dia temperatura: máxima: 28,3 mínimo: 24,6 média: 26,5. Unidade Relativa: máxima: 92, mínimo: 65. Condições do tempo: claro sem nuvens.

Quadro 3 - Valores de temperaturas aferidas nas salas de atuação da equipe de enfermagem da UBS. Volta Redonda/RJ, 2005.

\begin{tabular}{|c|c|c|c|c|c|c|}
\hline Medidor & Ginecol. & Nebul. & Curativos & Vacina & Esterel. & Farmácia \\
\hline $\begin{array}{l}\text { Termômet } \\
\text { ro de } \\
\text { Bulbo } \\
\text { Úmido }\end{array}$ & 24,7 & 24,7 & 24,7 & 24,7 & 24,7 & 24,7 \\
\hline $\begin{array}{l}\text { Termômet } \\
\text { ro de } \\
\text { Globo }\end{array}$ & 30,1 & 30,1 & 30,1 & 30,1 & 30,1 & 30,1 \\
\hline $\begin{array}{l}\text { Termômet } \\
\text { ro seco }\end{array}$ & $30,9^{\circ} \mathrm{C}$ & $32,0^{\circ} \mathrm{C}$ & $29,9^{\circ} \mathrm{C}$ & $30,5^{\circ} \mathrm{C}$ & $32,8^{\circ} \mathrm{C}$ & $30,0^{\circ} \mathrm{C}$ \\
\hline IBUTG & 26,3 & 26,3 & 26,3 & 26,3 & 26,3 & 26,3 \\
\hline
\end{tabular}


Os valores de IBUTG obtidos nas salas caracterizam condições térmicas que propiciam desconforto às trabalhadoras e aos usuários. De acordo com Iida (1990, p. 236), a zona de conforto térmico do ambiente é delimitada entre as temperaturas efetivas de 20 a $24 \mathrm{C}$, com umidade relativa de 40 a 60 , com velocidade do ar moderada da ordem de $0,2 \mathrm{~m} / \mathrm{s}$.

Existe uma deficiente circulação de ar nas salas que possuem janelas do tipo basculantes, que permitem pouca entrada e saída de ar. A temperatura eleva-se à medida que número de pessoas no ambiente aumenta e a porta é fechada. Portanto, durante a execução das tarefas assistenciais; sabe-se que a temperatura influi diretamente no desempenho do trabalho humano (IIDA, 1990, p. 231).

Em seus achados, Lopes; Spindola; Martins (1996, p. 13) mencionam que, dentre os riscos geradores de doenças no pessoal de enfermagem, encontram-se a temperatura ambiente e a planta física inadequada. Evidenciou-se a menção de desconforto quanto à temperatura pelos sujeitos do estudo.

\section{Iluminação}

Quanto à iluminação, as tarefas que têm exigências visuais são a leitura, execução e registros de procedimentos efetuados. É necessária luz artificial, geral ou local, nas salas e ambientes da UBS. 
Quadro 4 - Valores médios de iluminação (em LUX) obtidos nas salas de atuação da equipe de enfermagem da UBS. Volta Redonda/RJ.2005

\begin{tabular}{|c|c|c|c|}
\hline Postos de trabalho & Horário & $\begin{array}{c}\text { Nível de } \\
\text { iluminamento } \\
\text { (LUX) } \\
\text { Com luz artificial }\end{array}$ & $\begin{array}{c}\text { Nível de } \\
\text { iluminamento } \\
\text { (LUX) } \\
\text { Sem luz artificial }\end{array}$ \\
\hline Ginecol. & $13: 33$ & 898 & 691 \\
\hline Nebul. & $14: 12$ & 582 & 271 \\
\hline Curativos & $14: 29$ & 732 & 298 \\
\hline Vacina & $13: 43$ & 345 & 212 \\
\hline Esterel. & $14: 50$ & 948 & 786 \\
\hline Farmácia & $15: 06$ & 145 & 19 \\
\hline
\end{tabular}

Há iluminação natural no ambiente com uma janela tipo basculante medindo $2,40 \times 0,80 \mathrm{~m}$ a $1,80 \mathrm{~m}$ do piso e uma porta de madeira medindo $2,10 \mathrm{x}$ $0,70 \mathrm{~m}$. A cor das paredes é branca com revestimento de azulejo entre $1,55 \mathrm{~m}$ a 1,65 m (a partir do piso) nas salas mensuradas. A altura do teto é de 2,98 m. Porém, a iluminação artificial nas salas em que atuavam a equipe de enfermagem era do tipo de lâmpada fosforescente (2 calhas com 2 lâmpadas cada). 
Os níveis de iluminação a serem observados nos locais de trabalho são aqueles estabelecidos na NBR 5413, norma brasileira registrada no INMETRO (MARZIALE, 1995, p. 135). A iluminação recomendada para as dependências de modo geral dos serviços de saúde é variável entre 200 a 300 LUX.

Os níveis encontrados nos postos de trabalho eram suficientes para as atividades realizadas, exceto na farmácia. Verifica-se a necessidade de substituição de lâmpadas queimadas e/ou cansadas, limpeza de luminárias, instalação de novos pontos de luz e mais pontos de iluminação na farmácia, a fim de melhorar a leitura dos receituários pela enfermagem.

Um nível de iluminação baixo, um contraste visual insuficiente são causas de problemas visuais que podem gerar irritação nos olhos e cefaléias (SANTIAGO; ARBONA, 2000, p. 21).

\section{Ruído}

Em relação ao ruído, ouviam-se nas salas vozes e choro de crianças de forma intermitente. As fontes geradoras de ruído são a recepção (ruído oriundo de vozes dos usuários e choro de crianças) e a avenida (via pública) em frente ao estabelecimento (ruído de veículos e carros sonoros para publicidade em via pública)

Atualmente, a Associação Brasileira de Normas e Técnicas (ABNT, 1985) estabelece os parâmetros de conforto sonoro em espaços de saúde pela NBR-10 152 - níveis de ruído aceitáveis para diferentes ambientes hospitalares:

- Apartamentos, enfermarias, berçários, centros cirúrgicos.........35-45dB (A) 
- Laboratórios, áreas para uso do público $.40-50 \mathrm{~dB}(\mathrm{~A})$

- Serviços. $45-55 \mathrm{~dB}(\mathrm{~A})$

Os valores médios de ruídos encontrados na UBS através das medições encontram-se apresentados no Quadro 4.

Quadro 5 - Valores médios de ruídos em $\mathrm{dB}(\mathrm{A})$ aferidos nas salas de atuação da equipe de enfermagem da UBS. Volta Redonda/RJ, 2005

\begin{tabular}{|c|c|c|c|c|c|c|}
\hline Medidor & $\begin{array}{l}\text { Ginecol. } \\
\text { Porta }\end{array}$ & Nebul. & Curativos & Vacina & Esterel. & Farmácia \\
\hline $\begin{array}{l}\text { Valor } \\
\mathrm{dB}(\mathrm{A}) \\
\text { Porta } \\
\text { aberta }\end{array}$ & 76 & 67 & 71 & 73 & 73 & 73 \\
\hline $\begin{array}{l}\text { Porta } \\
\text { fechada }\end{array}$ & 58 & 59 & 58 & 65 & 65 & 64 \\
\hline $\begin{array}{c}\text { Tipo de } \\
\text { ruído }\end{array}$ & Intermitente & Intermitente & Intermitente & Intermitente & Intermitente & \begin{tabular}{|l|} 
Intermitente \\
\end{tabular} \\
\hline
\end{tabular}

Cabe mencionar as condições selecionadas para o momento da aferição, procurando considerar as fontes geradoras de ruído nas salas onde a enfermagem atuava.

Constatou-se que os níveis de ruído estão elevados em relação aos parâmetros 
considerados limites de acordo com a ABNT.

Níveis de intensidade de ruídos superiores aos estabelecidos são considerados de desconforto psicológico, acima de $65 \mathrm{~d}$ (A) podem implicar em riscos de danos à saúde, quando o tempo de exposição for prolongado e quando os valores excederem, em muito, os níveis recomendados.

Okamoto e Santos (1996, p. 89) indicam que, apesar de controversos e inconclusivos, os estudos sobre os efeitos da exposição do ruído a outros órgãos, para além do aparelho auditivo, demonstram que são cada vez maiores as evidências dos seus efeitos nocivos, em especial, na produção de alterações neuropsíquicas. Enfatizam que o estímulo, antes de alcançar o córtex do cérebro, percorre estações subcorticais, inclusive das funções vegetativas, o que explicaria os efeitos não auditivos ocasionados pelo ruído.

Quanto às alterações fisiológicas e neuropsíquicas mais encontradas, as autoras destacam a hipertensão arterial, incluindo as manifestações de ansiedade, desconfiança, pessimismo, depressão e alteração do ritmo sonovigília, na atenção e na memória. Apontam ainda que a exposição prolongada tem sido responsável por altas taxas de absenteísmo, cefaléia e acidente de trabalho, inclusive na condução de veículos (OKAMOTO; SANTOS, 1996, p. 91).

Diante das constatações sobre o ambiente de trabalho estudado, algumas medidas devem ser tomadas a fim de melhor adequação e bem estar das trabalhadoras de enfermagem.

Em relação ao ruído, o desconforto provocado pelo mesmo é relatado pelos participantes do estudo e comprovado seu nível elevado, especialmente na abertura de 
portas, que antecede as ações de enfermagem. Assim, é recomendado tratamento acústico nas paredes e ampliação da equipe de enfermagem, visando implementação de atividades de educação em saúde aos usuários na sala de espera, minimizando as fontes sonoras de barulho intenso.

Em relação à iluminação, não foi verificada inadequação, exceto no setor de farmácia, em que foram indicadas medidas de eliminação deste desconforto. Nos demais postos de trabalho, há iluminação natural, mas também artificial que favorecem a visão sob os ângulos de atuação profissional, embora haja recomendações sobre a manutenção adequada deste agente físico no ambiente estudado.

Não há sistema de segurança no ambiente para os trabalhadores (sistemas de vigilância). Existe sistema de segurança, com equipamentos, quanto ao acesso à UBS, ou seja, há um sistema de alarme anti-furtos, que é acionado a partir das 17:00 horas ao fechar as portas da unidade de saúde e desligado no início das atividades às 7:00 horas do dia seguinte.

Foi reconhecida a necessidade de sistema de segurança aos trabalhadores, para evitar os atos de agressões a que estão submetidos. 


\subsection{A atividade do trabalho e os fatores ergonômicos associados}

A atividade do trabalho é compreendida, neste estudo, como aquela efetivamente realizada, composta pelos seguintes elementos: tarefa (trabalho prescrito), a atividade real (a que efetivamente é executada) e o posto de trabalho onde as atividades são realizadas (MARZIALE, 1995, p. 83). Assim, será apresentada a seguir a realidade encontrada na UBS.

As tarefas prescritas para a equipe de enfermagem

De acordo com o Ministério da Saúde (BRASIL. MS., 2002, p. 6), a atenção básica em saúde pode ser compreendida como um conjunto de ações de caráter individual ou coletivo, situado no primeiro nível de atenção dos sistemas de saúde, voltado para a promoção da saúde, prevenção de agravos, tratamento e reabilitação.

Nestas ações, estão incluídas vacinação, atividades educativas aos grupos da comunidade, pequenas cirurgias, atendimentos básicos por profissionais de nível médio, orientação nutricional e alimentar, ambulatorial e comunitária e pronto atendimento (BRASIL. MT, 2002, p. 6).

Verificou-se que as tarefas prescritas para a enfermagem são condizentes com as ações preconizadas pelo Ministério da Saúde, porém acrescidas de outras tarefas que são prescritas e executadas.

O enfermeiro gerente atuava em função administrativa, porém também na atenção primária sempre que necessário, mediante intercorrências e/ou urgências que surgiam. Também em ações assistenciais sempre que havia sobrecarga das atividades para equipe de auxiliares e técnicos de enfermagem. Foi observada sua presença na 
organização diária das tarefas, direcionando e orientando os atendimentos, mas também executando atendimentos aos usuários e executando curativo.

As tarefas prescritas para os auxiliares e técnicos são as mesmas: vacinação (considerada a de maior fluxo assistencial), curativos, coleta de material para exames laboratoriais de rotina, teste do pezinho, aferição da pressão arterial, nebulização, administração de medicamentos injetáveis, entrega de medicamentos sob prescrição médica, pré-consultas, acompanhamento de consultas ginecológicas e de pré-natal e orientações gerais (que ocorrem permanentemente durante a jornada diária).

Conforme proposto neste estudo, foi abordada a atividade de vacinação.

\section{Atividade efetivamente realizada}

A prática de vacinação as envolve nas seguintes etapas: o início do trabalho diário, a triagem, a orientação específica, a administração dos imunobiológicos e o encerramento do trabalho diário e do trabalho mensal (ROCHA, 2001, p. 54).

De acordo com o manual de procedimentos em vacinação (ROCHA, 2001, p. 55), no início das atividades, a equipe executa a verificação das condições da sala de vacinação em relação ao acondicionamento dos imunobiológicos, limpeza e refrigeração para sua conservação;

- a triagem engloba verificar se a pessoa está comparecendo pela primeira vez, abrir o documento de registro da vacinação, o cartão da criança, orientar sobre a importância da vacinação e do esquema básico, fazer registro da vacina a ser administrada, fazer o aprazamento (verificar a data de retorno para nova dose de vacina), encaminhar a pessoa para o imunobilógico indicado;

- na administração dos imunobiológicos implica lavar as mãos, examinar o produto 
observando a aparência da solução, o estado de embalagem, o prazo de validade, a via de administração, o número de lote e a dosagem, preparar segundo a técnica específica, observar reações imediatas, rubricar o documento, reforçar orientações, desprezar o material e lavar as mãos.

- o encerramento das atividades diárias compreende separar os cartões de controle ou fichas de registro, verificar os imunobiológicos quanto ao prazo estabelecido para abertura do frasco, verificar acondicionamento e temperatura para conservação dos mesmos.

Apresenta-se a seguir, nos Quadros 6 e 7, o fluxo da atividade de vacinação e seu tempo de execução. 
Quadro 6 - Tempo gasto (em segundos) pelo auxiliar de enfermagem na sala de vacinação para execução desta atividade durante o turno da tarde (vacina BCG)

\begin{tabular}{|c|c|}
\hline $\begin{array}{c}\text { Atividade } \\
\text { Vacina BCG }\end{array}$ & $\begin{array}{l}\text { Tempo de execução } \\
\text { Horário da tarde }\end{array}$ \\
\hline Chamar os usuários na sala de espera & $10 \mathrm{seg}$ \\
\hline $\begin{array}{l}\text { Acolher o usuário (criança e mãe) na sala de } \\
\text { vacinação }\end{array}$ & $10 \mathrm{seg}$ \\
\hline Realizar o aprazamento no cartão de vacina & $15 \mathrm{seg}$ \\
\hline $\begin{array}{l}\text { Orientar a mãe sobre o aprazamento e sobre a } \\
\text { vacina }\end{array}$ & $15 \mathrm{seg}$ \\
\hline Lavar e secar as mãos & $35 \mathrm{seg}$ \\
\hline Preparar a vacina & $50 \mathrm{seg}$ \\
\hline Colocar os óculos de proteção & $10 \mathrm{seg}$ \\
\hline $\begin{array}{l}\text { Retornar à mãe e orientar sobre a posição da } \\
\text { criança e da mãe para receber a vacina }\end{array}$ & $240 \mathrm{seg}$ \\
\hline Aplicar a vacina & $20 \mathrm{seg}$ \\
\hline Orientar sobre os cuidados à mãe & $35 \mathrm{seg}$ \\
\hline Registrar no cartão e entregá-lo à mãe & $5 \mathrm{seg}$ \\
\hline $\begin{array}{l}\text { Descartar o material usado no descarpack e lixo } \\
\text { biológico }\end{array}$ & $5 \mathrm{seg}$ \\
\hline Lavar e secar as mãos & $10 \mathrm{seg}$ \\
\hline Encaminhar ficha à recepção & $10 \mathrm{seg}$ \\
\hline Total & 7 minutos e $50 \mathrm{seg}$ \\
\hline
\end{tabular}


Em relação à atividade de vacinação contra hepatite $\mathrm{B}$, o quadro que segue representa o fluxo desta atividade e o tempo gasto para a sua execução.

Quadro 7 - Tempo gasto (em segundos) pelo auxiliar de enfermagem na sala de vacinação para execução desta atividade durante o turno da tarde (vacina Hepatite B)

\begin{tabular}{|c|c|}
\hline $\begin{array}{c}\text { Atividade } \\
\text { Vacina Hepatite B }\end{array}$ & $\begin{array}{l}\text { Tempo de execução } \\
\text { Horário da tarde }\end{array}$ \\
\hline A triagem e a orientação específica & \\
\hline Chamar os usuários na sala de espera & $10 \mathrm{seg}$ \\
\hline $\begin{array}{l}\text { Acolher o usuário (criança e mãe) na sala de } \\
\text { vacinação }\end{array}$ & $10 \mathrm{seg}$ \\
\hline Realizar o aprazamento no cartão de vacina & $15 \mathrm{seg}$ \\
\hline $\begin{array}{l}\text { Orientar à mãe sobre o aprazamento e sobre a } \\
\text { vacina }\end{array}$ & $15 \mathrm{seg}$ \\
\hline Orientar sobre os cuidados à mãe & $30 \mathrm{seg}$ \\
\hline Administração dos imunobiológicos & \\
\hline Lavar e secar as mãos & $15 \mathrm{seg}$ \\
\hline Preparar a vacina & $37 \mathrm{seg}$ \\
\hline Colocar os óculos de proteção & $10 \mathrm{seg}$ \\
\hline $\begin{array}{l}\text { Retornar à mãe e orientar sobre a posição da } \\
\text { criança e da mãe para receber a vacina }\end{array}$ & $10 \mathrm{seg}$ \\
\hline Aplicar a vacina & $7 \mathrm{seg}$ \\
\hline Registrar no cartão e entregá-lo à mãe & $5 \mathrm{seg}$ \\
\hline $\begin{array}{l}\text { Descartar o material usado no descarpack e lixo } \\
\text { biológico }\end{array}$ & $5 \mathrm{seg}$ \\
\hline Lavar e secar as mãos & $10 \mathrm{seg}$ \\
\hline Encaminhar ficha à recepção & $10 \mathrm{seg}$ \\
\hline Total & 3 minutos e 9 seg \\
\hline
\end{tabular}


Verificou-se, no primeiro dia de observação (120 minutos no horário da tarde), a execução de nove atendimentos em vacinação $B C G$, seis em hepatite $B$, quatro em teste do pezinho. Estes atendimentos foram às pessoas adultas, idosas e crianças.

Notou-se que o tempo gasto com a vacinação BCG era maior em função dos cuidados específicos que a mesma exige, especialmente no posicionamento da criança. No momento da aplicação da vacina, a auxiliar de enfermagem adotava a postura sentada, porém sem encostar a coluna vertebral, conforme Figura 28.

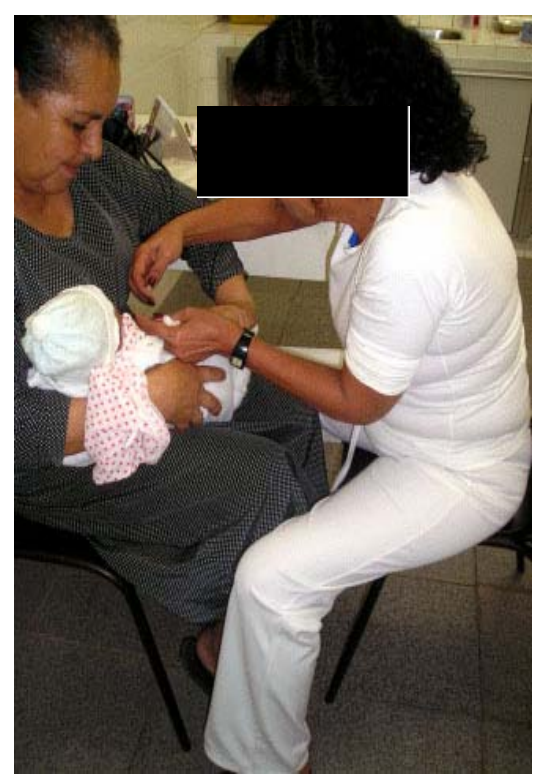

Figura 21 - Aplicação de vacina BCG e a postura adotada pela profissional

Os ritmos eram intensos de deslocamentos entre a triagem, preparo de vacina e orientações alternando as posturas adotadas pela profissional.

A postura, segundo Marziale (2000, p. 125), submete-se às características anatômicas e fisiológicas do corpo humano, ligando-se às limitações específicas do equilíbrio e obedecendo às leis da física e iomecânica e, ainda, de outra parte, a mesma mantém estreito relacionamento com a atividade do indivíduo, podendo 
aumentar ou diminuir o esforço físico de um trabalho.

Segundo Santiago e Arbona (2000, p. 33), de forma geral, todos os trabalhos que implicam grande esforço muscular e deslocamentos realizam-se na posição de pé. A posição implica sobrecarga dos músculos das pernas e ombros, portanto faz-se necessário que em trabalhos nesta posição, como em qualquer outra, seja proporcionado mudanças para outras posições, diminuindo assim a carga física postural.

Esta posição provoca fatiga, má circulação sanguínea nos membros inferiores do trabalhador, podendo causar varizes e outros transtornos circulatórios (SANTIAGO; ARBONA, 2000, p. 33).

Durante o período de observação, houve apenas uma pausa (10 minutos) da profissional de enfermagem. Segundo depoimento da mesma ao final da jornada, sente dores nos membros inferiores-MMII como "se tivesse chumbo nas pernas"

Para amenizar os efeitos desta carga, Couto (1996, p. 15) revela que algumas regras básicas devem ser observadas para o uso do corpo no local de trabalho. O corpo deve trabalhar na vertical; as duas mãos devem começar e completar os movimentos de uma só vez; os braços devem ser movimentados de forma simétrica, em direção oposta, de forma simultânea; os movimentos das mãos devem ser simplificados e facilitados; deve-se usar a força da gravidade para o transporte de material.

Alguns fatores determinam adoção de posturas inadequadas no trabalho de enfermagem. Bulhões $(1998$, p. 128) refere à influência do espaço de trabalho e do dimensionamento dos móveis, observando-se simultaneamente as características 
antropométricas, idade e ocorrência de fadiga. No que se relaciona à postura, todos aqueles atos que mantêm o corpo inclinado para frente, bem como os que ocorrem com rotação da coluna, produzem nos trabalhadores de enfermagem doenças ósteo-articulares, como dores lombalgias e cervicalgias incapacitantes. A postura prolongada é nociva, a de pé ocasiona varizes, a sentada, hemorróidas e a inclinada ocasiona cifose ou escoliose.

É mister destacar um problema maior, enfatizando o esforço da mão e braço para manter a perfuração da agulha na pele da criança que se movimenta. Exige-se, então, um excesso de concentração mental para evitar o erro, força e sustentação dos dedos, mãos e braços para não mudar de posição, mesmo com o movimento da criança. Assim, há desconforto e pode causar fortes dores musculares.

Ao analisar a situação na UBS, observou-se grande vulnerabilidade dos profissionais a essa carga, dada à incorreta postura adotada nos diversos setores de atuação. No entanto, o maior risco encontrou-se na sala de vacinas, na administração de imunobiológicos: os profissionais permanecem de pé por longos períodos, alternando a posição curvada, ao vacinarem crianças no colo das mães sentadas em cadeiras. Há de se atentar ainda para a grande demanda do setor e, portanto, para a constante repetição desses movimentos durante a jornada de trabalho, uma vez que Zeitoune (1996, p. 101) identificou que as atividades no setor de vacina provocam desconforto lombar no profissional de enfermagem. 


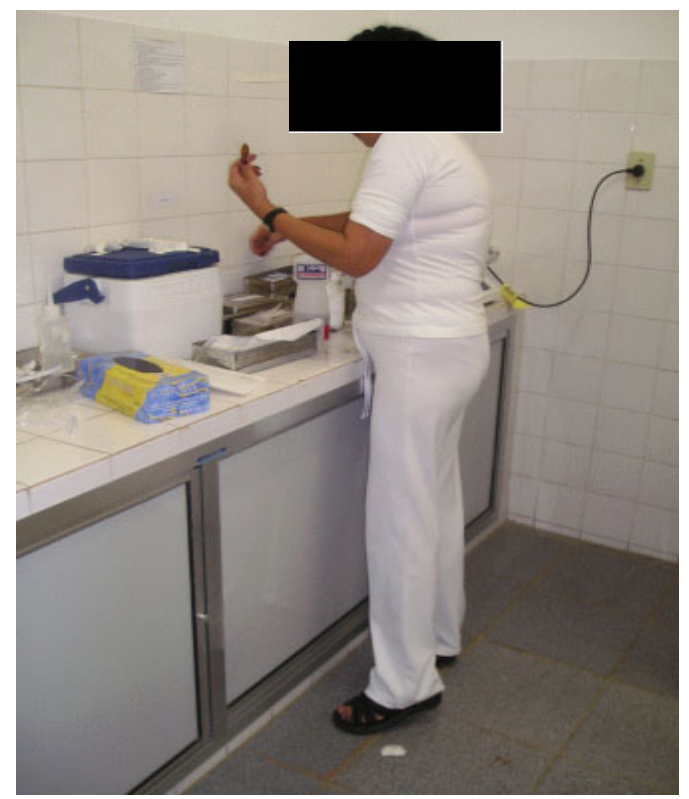

Figura 22 - Preparo da vacinação na posição em pé

A atenção permanente para realizar a atividade foi observada no trabalho de enfermagem e reconhecida pelas trabalhadoras. Isto foi devido à freqüente necessidade de concentração para realização das atividades nos diversos programas de saúde, os quais envolvem grande número de tarefas de significativa responsabilidade e geram ritmo intenso de trabalho. Portanto, a alta demanda aliada a esta necessidade provavelmente causa grande tensão para os trabalhadores.

O sintoma físico mais apontado pelos sujeitos desta equipe, relativos à fase de resistência do processo de estresse, foi a sensação de cansaço constante.

O estresse, quando presente no indivíduo, pode desencadear uma série de doenças. Se nada é feito para aliviar a tensão, a pessoa cada vez mais se sentirá exaurida, sem energia e depressiva. Na área física, muitos tipos de doenças podem 
ocorrer, dependendo da herança genética da pessoa. Uns adquirem úlceras, outros desenvolvem hipertensão, outros ainda têm crise de pânico, de herpes e outras doenças (CAMELO; ANGERAMI, 2004).

Para Stacciarini e Tróccoli (2001, p. 18), o estresse é difícil de conceituar e pode ser entendido de formas distintas. Estes autores descrevem que, em uma das abordagens mais produtivas sobre o estresse ocupacional, ele é um problema negativo, de natureza perceptiva, resultado da incapacidade de lidar com as fontes de pressão no trabalho.

Zeitoune (1996, p. 64), em seu estudo sobre desconforto lombar e as variáveis cinemáticas da postura do profissional de enfermagem, ressalta que o tempo de trabalho no mesmo setor, sem alternância, pode representar também situação de estresse.

A sala de vacinas da UBS apresenta estas situações de estresse, geradas normalmente pela clientela. O ambiente é ruidoso, com choro de crianças, tensão da mãe acompanhante, que passa para o profissional, entre outras intercorrências. Estar exposto a esses fatores, associado ao longo período de trabalho, durante anos consecutivos, no mesmo setor, pode representar fator de risco para a coluna vertebral do trabalhador, levando a crer que as atividades desenvolvidas no setor são responsáveis por lombalgias e desvios da coluna vertebral.

As posturas de adotadas estão representadas na Figura 23 a seguir. 


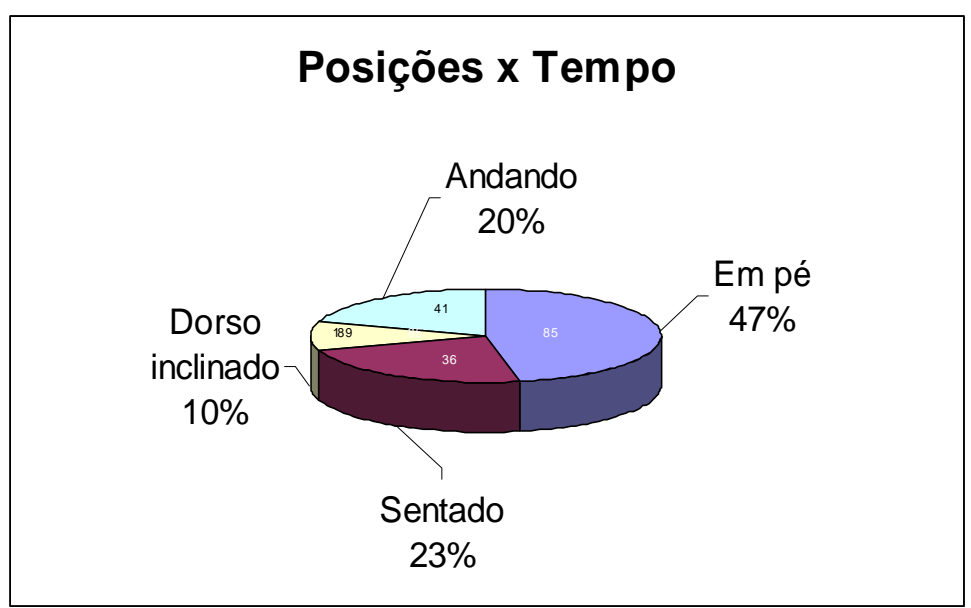

Figura 23 - Posições adotadas pelo auxiliar de enfermagem na sala de vacinação

Verificou-se que os deslocamentos eram constantes e as posturas observadas foram em pé ( $85 \mathrm{~min}$.$) , sentada (36 min.), andando (41 min.) e dorso inclinado (18$ min.). Mauro e Cupello (2001), em seus estudos sobre o trabalho de enfermagem sob a abordagem ergonômica, constataram que a sobrecarga dos trabalhadores de enfermagem estaria relacionada à vulnerabilidade, simultaneidade e excessiva responsabilidade depositada aos poucos funcionários que não permitem pausa, nem alimentação adequadas. Observou-se que as posições de pé e andando são as mais desgastantes, o que leva a uma relação direta com o estresse e cansaço ocasionado. 


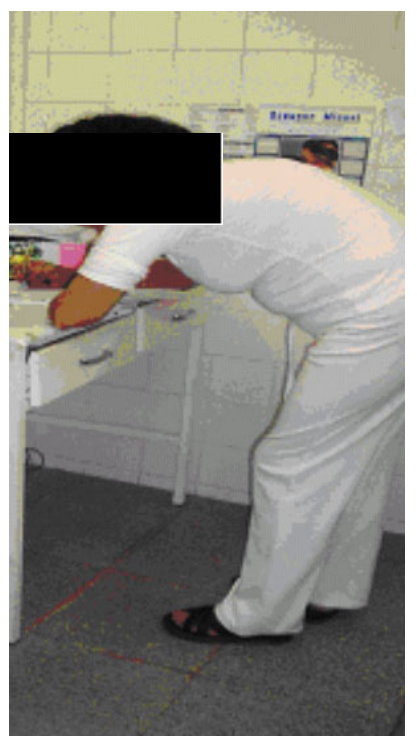

Figura 24 - Registros feitos pela trabalhadora durante a vacinação na posição inclinada e de pé

A permanência em pé pode provocar cãibras, distúrbios circulatórios, osteomusculares e fadiga muscular nos membros inferiores, além de fadiga generalizada. A fadiga é resultado de um trabalho continuado que ocasiona uma diminuição reversível da capacidade do organismo e uma degradação na qualidade do trabalho. Tanto a fadiga como a cãibra e as varizes são decorrentes de uma jornada de trabalho excessiva, em que é necessária a permanência da posição de pé por um período contínuo e repetido rotineiramente (MAGALHÃES; MÁSCULO, 2000, p. 22).

A observação da atividade na UBS sugere esforços físico, cognitivo e psicossocial e envolvem fatores organizacionais, os quais serão descritos a seguir.

\section{Esforço físico:}

Havia deslocamentos constantes durante a jornada de trabalho, especialmente entre a ação de receber os usuários, preparar a administração, administrar o 
imunobiológico e encaminhar ficha à recepção;

Permanência na posição estática em pé na maior parte do tempo.

\section{Esforços cognitivo e psicossocial:}

coordenação e controle de todas as atividades de vacinação; em alguns momentos os trabalhadores exerciam o controle sobre a situação de choro e impaciência das crianças ao serem vacinadas;

número elevado de repetidas orientações feitas várias vezes permanentemente, antes, durante e após a aplicação dos imunobiológicos;

concentração no preparo e durante a atividade de vacinação, muitas vezes atendendo simultaneamente às dúvidas das mães;

atenção ao uso de EPI e ao descarte do material usado.

\section{Fatores organizacionais}

dimensionamento inadequado na quantidade de profissionais auxiliares e técnicos de enfermagem, gerando freqüente sobrecarga e insatisfação na equipe ;

falta de supervisão direta e treinamento, pois foi observado o uso inadequado de EPI durante a execução do teste do pezinho, constatando-se que uma auxiliar de enfermagem realizava a atividade com luva em apenas uma das mãos;

quantidade insuficiente de óculos de proteção na vacina BCG. Havia apenas um para ser usado por todas as profissionais de enfermagem. 
Zeitoune (1996, p. 101) evidenciou, em seu estudo, que o procedimento de administrar os agentes imunobiológicos em crianças pode contribuir no desencadeamento da lombalgia e que parte dessa problemática estaria certamente resolvida se a atividade não fosse vista como um ritual, ou seja, pertinente ao exercício da profissão. Ressaltou a necessidade de que o profissional de enfermagem deva ser mais crítico e questionador em relação ao seu ambiente de trabalho e a sua rotina, evitando a realização de tarefa de forma ritualista. Por isso, as questões ergonômicas devem ser consideradas, discutidas e tratadas pela enfermagem e demais membros da UBS.

É importante que o profissional de enfermagem conheça os princípios que regem a mecânica corporal e os aplique na sua prática de forma que os movimentos se tornem suaves e se realizem com um mínimo de esforço para os músculos do corpo. Para isso, devem-se realizar treinamentos posturais, técnicas de relaxamento e educação para a promoção da saúde, além das adequações do ambiente e mobiliário.

Quando estas questões não são atendidas, o trabalhador convive com situações de violência laboral.

O trabalhador é violentado quando não lhe é propiciado boas condições de trabalho, a população é violentada quando não recebe uma assistência de qualidade. Assim, se forma uma rede de violência direta e indireta com o trabalhador que, sem condições adequadas, gera nele o sofrimento de não conseguir desempenhar satisfatoriamente suas funções. Mesmo assim, ele faz aquilo que é possível dentro das condições de trabalho que lhe são oferecidas, mas ao atuar o faz de forma deficiente, violentando de forma indireta a população. Esta, por sua vez, reage agredindo o trabalhador, física ou moralmente, direta ou indiretamente, dependendo da situação e 
da personalidade das pessoas envolvidas (COSTA, 2005).

As condições de trabalho e a sobrecarga provavelmente limitam a competência profissional. Remetem à violência ocupacional, uma vez que o trabalhador insatisfeito exerce mal suas responsabilidades, refletindo um cotidiano mecanizado, desumano e improdutivo.

No percurso desta pesquisa, pode-se concluir ainda que o processo trabalho de enfermagem em saúde coletiva é realizado sob influência da enfermagem tradicional e traduz as grandes conseqüências de seu modo de produção. Por meio da abordagem ergonômica, percebeu-se que as ações de enfermagem são essencialmente técnicas e estão fragmentadas em relação à integralidade proposta para o agir em saúde coletiva, o que repercute na resolutividade da atenção prestada e no direito da população.

Outro aspecto observado no trabalho nas UBS é a violência em que os trabalhadores da equipe de enfermagem, ora atores, ora vítimas de atos violentos estão reproduzindo e perpetuando situações de agressividade que vêm prejudicando a assistência prestada aos clientes e ocasionando o adoecimento pelo trabalho. A situação apresentou fatores de penosidade que podem estar interferindo na condição de saúde das trabalhadoras. 


\section{Recomendações}

Considerando as constatações na UBS, serão apresentadas a seguir as recomendações, com vistas à intervenção ergonômica, visando a melhoria das condições de trabalho na situação de trabalho estudada.

Concepção: reorganização do trabalho com a participação do pessoal na determinação de suas condições ocupacionais e de vida e participação em tudo que contribui para sua satisfação no trabalho. Os dados antropométricos da equipe de enfermagem devem ser considerados para melhorias nas condições e postos de trabalho.

Correção: para adequar as condições de trabalho às características da equipe de enfermagem, recomenda-se:

estudo pela gestão pública sobre a remuneração para que seja mais digna;

oportunidade de carreira, descanso e pausas, segurança social, proteção à saúde, com o acompanhamento e apoio do Programa de Saúde do Trabalhador; redimensionamento do efetivo de pessoal de enfermagem na UBS; oportunidade de atualização e educação contínua à equipe de enfermagem; reformulação nas formas de reconhecimento e valorização dos trabalhadores e de suas atividades e função;

enriquecimento do trabalho, e não apenas das tarefas, mediante capacitação profissional, planejada e reconhecida pelos trabalhadores;

possibilidades de desenvolvimento na profissão, com participação em atividades culturais e científicas, favorecendo desta forma a motivação da equipe; 
atividades em grupo de lazer e técnicas em grupo, estimulando o trabalho em equipe;

monitoramento e acompanhamento das condições de saúde da equipe;

educação e orientações nutricionais aos trabalhadores;

medidas educativas para a prevenção de acidentes, bem como para o uso apropriado de EPI;

EPI em qualidade e em quantidade suficientes e adequados;

treinamento acerca das mudanças tecnológicas dos materiais a serem usados nos procedimentos com comunicação e orientações adequados e em tempo hábil, como norma de segurança, para evitar-se os acidentes;

treinamento em imunizações e teste do pezinho visando atualização nesta atividade;

melhorias nas condições dos postos e ambiente de trabalho com adequações de alturas de bancadas, aquisição de cadeiras que proporcionem descanso e conforto;

implantação de sistemas de segurança (guarda de segurança) e capacitação acerca das formas de atuar sob as condições de violência;

sistema de iluminação adequado, incluindo-se a substituição de lâmpadas queimadas e/ou cansadas, limpeza de luminárias, instalação de novos pontos de luz e limpeza das paredes;

adequação dos mobiliários que se encontram com dimensões inadequadas e quebrados, no mínimo, nos locais onde existia restrição, viabilizando o seu uso, 
favorecendo, então, maior bem estar dos funcionários, reduzindo os riscos e probabilidade de acidentes no trabalho e doenças osteo-musculares; ao ruído proveniente da conversação, independentemente do projeto arquitetônico, que pode ser minimizado com o tratamento interno das superfícies da vedação com materiais absorvedores acústicos. Por exemplo, as circulações internas, devido ao movimento, ao paralelismo e às fortes e repetidas reflexões geram muitos ruídos, afetando as salas e postos de trabalho;

melhorias coletivas no apoio e qualidade operacionais e organizacionais do processo de trabalho;

Conscientização: É necessário sensibilizar a equipe de enfermagem quanto aos aspectos de segurança no trabalho, com treinamentos específicos nesta área e nas atividades desenvolvidas pela enfermagem. O município é favorecido em sua estrutura de gestão por um programa em saúde ocupacional. Assim, deve reforçar as políticas e ações de vigilância em saúde do trabalhador e de gestão dos recursos humanos para o SUS, conforme preconizado pelo Ministério da Saúde.

Em relação à violência é recomendado:

\section{Em Condições Prévias}

Desenvolver uma cultura no trabalho centrada nos aspectos humanos;

Aumentar a sensibilização dos trabalhadores e da comunidade, no local de trabalho, chamando a atenção para os prejuízos da violência; Intervenções nas organizações: 
Proporcionar dimensionamento adequado de pessoal;

Adotar um estilo de gerencia baseado na comunicação e diálogo, em que se priorize atitudes solícitas e de respeito à dignidade das pessoas no trabalho;

Prover formação e comunicação abertas, visando minimizar a tensão e frustração dos trabalhadores. Devem-se fomentar sessões de informações, reuniões e trabalho em equipe e debates em grupo;

Dar informações pertinentes aos usuários, familiares e público em geral, para reduzir o risco de violência aos trabalhadores;

Informar aos trabalhadores sobre as situações determinantes de riscos, como em caso de visitas domiciliares e a entrada de ambulância e outros veículos do serviço de saúde em lugares perigosos. Devem-se marcar as visitas previamente, em horário adequado e acordado, bem como manter contatos com a polícia local, para informações atualizadas sobre as situações e locais que possam gerar atitudes violentas antes que aconteçam; adoção de protocolos de rotinas;

Melhorar as práticas no trabalho, onde cada situação é única, devese adotar uma combinação de medidas que possam responder a cada situação: evitar aglomerações, reduzir o tempo de espera do usuário, tornar o serviço mais ágil e resolutivo.

\section{Intervenções nos espaços}

Adequar o desenho dos postos de trabalho deve ser adequado às 
tarefas, evitando sobrecarga, minimizando ritmos excessivos, facilitando o acesso dos trabalhadores de apoio e da equipe;

- Físico:

- controlar o nível de ruído, ventilação, iluminação e temperatura, para evitar irritação e tensão de trabalhadores e usuários;

- usar cores que produzam descanso.

- O desenho do local do trabalho deve:

- Propiciar espaço adequado para a prestação de serviço e para o descanso dos trabalhadores;

- Ter salas de espera com assentos, materiais de leitura, televisão e jogos educativos;

- Possuir sistemas de alarme e câmaras de vigilância.

\section{Intervenções nas pessoas}

Proporcionar formação adequada e orientações, assistência e assessoria para ajudar as pessoas a reconhecerem situações de perigo, trocar informações sobre atitudes e condutas e como encaminhar alguns casos de violência no trabalho e provenientes dos domicílios dos usuários.

Embora a temperatura estivesse elevada e desconfortante, a equipe de enfermagem poderá fazer uso dos ventiladores de teto nos postos, nos momentos em que não estão efetuando suas atividades.

São imprescindíveis a implantação e implementação de mecanismos de 
apoio, de educação, ações pertinentes e de políticas que foram abordadas neste estudo, para que o processo de trabalho em saúde coletiva atinja seus propósitos de bem e manutenção da vida da população, mas também alcance a dimensão éticopolítica da vida social no trabalho, de forma que promova a cidadania de seus próprios trabalhadores. 


\section{Conclusões}

Este estudo analisou as condições ergonômicas do trabalho de enfermagem na Unidade Básica de Saúde. Inicialmente, foi feita a identificação da demanda ergonômica, apontada a partir dos dados de adoecimento e afastamentos da equipe de enfermagem nessa UBS.

Nas características dos trabalhadores de enfermagem que atuavam neste local, evidenciou-se o excesso de peso e o uso de cigarro. As medidas antropométricas permitiram correlacionar algumas inadequações dos mobiliários nos postos de trabalho.

O ambiente em que a equipe de enfermagem da UBS trabalhava necessita de intervenção ergonômica, especialmente em relação ao ruído e à temperatura.

Há de se destacar que a equipe de enfermagem sofre com a ausência de recursos e de possibilidades para resolução dos problemas de saúde da clientela. Eram situações difíceis, tanto para os funcionários quanto para os clientes e respectivos familiares que, por vezes, extravasavam seu descontentamento com agressões verbais. A presença de clientes alcoolizados, drogados ou com situações do atendimento relacionadas às brigas e homicídios eram determinantes das violências verbais sofridas pela equipe, o que gerava ansiedade e insegurança.

A análise da atividade de vacinação, efetivamente realizada pelos profissionais de enfermagem, permitiu verificar os deslocamentos constantes e o tempo prolongado na posição de pé e o esforço mental e de membros superiores, gerando cansaço, "peso" nos membros inferiores e risco às manifestações clínicas e complicações nos casos de hipertensão arterial. Esta última foi dos agravos de 
saúde identificados nos profissionais.

Constataram-se diversas formas de violência operantes no mundo do trabalho de enfermagem nessa UBS. O processo de trabalho, por sua vez, fortalecia as violências do tipo estruturais e comportamentais, impondo ritmos e modos técnicos de atuar estressantes e demonstrando uma forma de enfrentamento das trabalhadoras aos determinantes evidenciados.

A abordagem ergonômica permitiu concluir que as trabalhadoras não possuem plenas condições de trabalho, são insatisfatórias.

As condições dos postos de trabalho, o insuficiente dimensionamento da equipe, a agressividade dos clientes e a falta de treinamentos foram os determinantes dos problemas encontrados na situação de trabalho analisada. Portanto, pode-se inferir que a realidade vivida pela enfermagem na UBS interferia na organização e qualidade de vida no trabalho em saúde coletiva, culminando na influência sobre sua saúde, desempenho e bem-estar. 


\section{Referências}

ABRAHÃO, J. Ergonomia: modelo, métodos e técnicas. Florianópolis: Abergo, 1993.

ABRAHÃO, J.; PINHO, D. L. M. Teoria e prática ergonômica: seus limites e possibilidades. In: PAZ, M. G. T.; TAMAYO A.. Escola, saúde e trabalho: estudos psicológicos. Brasília: Editora Universidade de Brasilia, 1999. p. 229-240.

ABRAHAO, J. I.; PINHO, D. L. M. As transformações do trabalho e desafios teórico-metodológicos da Ergonomia. Estud. Psicol., Natal, v. 7, p. 45-52, 2002.

ABRANCHES, S. S. Fatores de riscos e agravos à saúde de trabalhadores de manutenção industrial em siderurgia na perspectiva da enfermagem. 2000. 108 f. Dissertação (Mestrado) - Universidade do Estado do Rio de Janeiro, Rio de Janeiro, 2000.

ALEXANDRE, N. M. C. Ergonomia e as atividades ocupacionais da equipe de enfermagem. Rev. Esc. Enfermagem USP, v. 32, n. 1, p. 84-90, abril 1998a.

ALEXANDRE, N. M. C. Aspectos ergonômicos relacionados com o ambiente e equipamentos hospitalares. Rev. Latino-am. Enfermagem, Ribeirão Preto, v. 6, n. 4, p.103-109, outubro 1998 b.

ALEXANDRE, N. M. C.; MORAES, M. A. A. Proposta educativa com enfoque ergonômico para auxiliar na prevenção de lesões músculo-esqueléticas na equipe de enfermagem. Rev. Bras. Enfermagem, Brasília, v. 51, n. 4, p. 629-642, outubro/dezembro 1998c.

ALEXANDRE, N. M. C.; ROGANTE, M. M. Dispositivos e equipamentos ergonômicos. In: ROGANTE, M. M.; PADOVEZE, M. C. Padronização, qualificação e aquisição de materiais e equipamentos médico-hospitalares. São Paulo: EPU, 2001.

ALMEIDA, A. W. B. Conflitos sociais no campo e cidadania. In: Violência no campo. Rio de Janeiro: Vozes/Fase, 1988. p. 132-147.

ALMEIDA, M. C. P.; ROCHA, S. M. M. O trabalho de Enfermagem. São Paulo: Cortez, 1997. 296 p.

ALVES, M.; PENNA, C. M. M.; BRITO, M. J. M. Perfil dos gerentes de unidades básicas de saúde. Rev. Bras. Enfermagem, Brasília, v. 57, n. 4, p. 441-446, julho/agosto 2004 . 
ANDRADE, O. B.; ADAMI, N. P. Considerações das funções da enfermeira de saúde pública. Rev. Fundacentro, São Paulo, ano III, n.13, p.21, abril 1996. Edição especial.

APUD, E.; MEYER, F. La importância de la ergonomía para los profesionales de la salud. Ci. y Enfermeria, Concepción, v. 9, n. 1, p. 15-20, junio 2003.

ARANDA, C. M. S. de Souza et al. Manual de procedimentos para vacinação. $4^{\mathrm{a}}$ ed. Brasília: Ministério da Saúde: Fundação Nacional de Saúde, 2005. 97 p.

ASSOCIAÇÃO BRASILEIRA DE ENFERMAGEM. A classificação internacional das práticas de enfermagem em saúde coletiva: CIPESC. Brasília, 1999. 56p. Série Didática Enfermagem no SUS.

. Decreto $\mathrm{n}^{\mathrm{o}} 94.406$ de 08 de junho de 1987. In: CONSELHO REGIONAL DE ENFERMAGEM DO RIO DE JANEIRO. Código de ética dos profissionais de enfermagem. Rio de Janeiro, p. 25.

. Salário mínimo. Diário Oficial do Estado Rio de Janeiro. Disponível em: http://www.portalbrasil.net/salariominimo.htm\#Salário\%20 Mínimo. Acesso em: 26 de junho de 2005.

ASSOCIAÇÃO BRASILEIRA DE NORMAS TÉCNICAS. ABNT.NBR - 10152

(NB-95): níveis de ruído para conforto acústico. Rio de Janeiro, 1985.

BRASIL. Leis, decretos, etc. Portaria MS/GM no 737 de 16/05/01. Política Nacional de redução da morbimortalidade por acidentes e violências. Diário Oficial da União, Brasília, no 96 seção 1e, de 18/05/01, 2002.

Portaria no 198/GM/MS. Institui a Política Nacional de Educação Permanente em Saúde e dá outras providências. 2004.

BRASIL. Ministério da Saúde. $8^{\text {a }}$ Conferência Nacional de Saúde. Bol. Inf.,. Brasília, 1986. 
. Programa atenção básica (PAB): parte fixa. 2 ed. rev. e atualizada. Brasília: Ministério da Saúde, Secretaria Executiva, 2002 . 28p.

Princípios e diretrizes para a gestão do trabalho no SUS (NOB/RH-

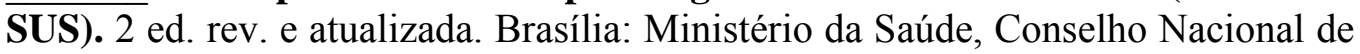
Saúde, 2003. 111p.

. Princípios e diretrizes para a gestão do trabalho no SUS (NOB/RHSUS). 3 ed. rev. e atualizada. Brasília: Ministério da Saúde, Conselho Nacional de Saúde, 2005. 97p.

Ministério do Trabalho. Manual de aplicação da norma regulamentadora $\mathrm{n}^{\circ} 17.2^{\mathrm{a}}$ ed. Brasília: MIE, SIT, 2002. $101 \mathrm{p}$.

BOFF, L. Saber cuidar: ética do humano-compaixão pela terra. Petrópolis: Vozes, 1999. 199p.

BULHÕES, I. Riscos do trabalho de enfermagem. Rio de Janeiro: Folha Carioca, 1998. 278 p.

CAMELO, S. H. H.; ANGERAMI, E. L. S. Sintomas de estresse nos trabalhadores atuantes em cinco núcleos de saúde da família. Rev. Latino-am. Enfermagem, Ribeirão Preto, v. 12, n.1, janeiro/fevereiro 2004.

CARY, L. C.; NAOMI, S. Workplace violence in the health sector: state of the art. OIT,OMS,CIE e ISP, 2002.

CASTELLANOS, P. L. Epidemiologia,saúde pública,situação de saúde e condições de vida considerações conceituais. In: BARATA, R. B. (Org.). Condições de vida e situação de saúde. Rio de Janeiro: ABRASCO, 1989. p. 3175 .

CEZAR, E. S. Problemas de violência ocupacional em um serviço de urgência hospitalar da cidade de Londrina-Paraná. 2005. Dissertação (Mestrado) Escola de Enfermagem de Ribeirão Preto/USP, Ribeirão Preto, 2005

COCCO, M. I. M. Reestruturação produtiva e o setor saúde: trabalhadores de enfermagem em saúde coletiva. 1997. 258 f. Tese (Doutorado) - Escola de Enfermagem de Ribeirão Preto/USP, Ribeirão Preto, 1997. 
CONSEJO INTERNACIONAL DE ENFERMERAS/ICN (CIE). La protección de los intereses del personal de Enfermeria. Guias sobre la seguridad en el trabajo: questiones a discutir. Genebra (Suiza): Editora CIE, abr. 1986.

CORREA, E. A. ; KRUCZAN, A. Doenças relacionadas à obesidade. Saúde, sexo \& educação, ano XII, n. 34-35, p. 3- 82 , 2004.

COSTA, A. L. R. C. As múltiplas formas de violência no trabalho de enfermagem: o cotidiano de trabalho no setor de emergência e urgência clínica de um hospital público. 2005. Tese (Doutorado) - Escola de Enfermagem de Ribeirão Preto/USP, Ribeirão Preto, 2005.

COUTO, H. A. Guia de bolso de ergonomia aplicada ao trabalho. Belo Horizonte: Ergo, 1996. 124 p.

DEJOURS, C. A banalização da injustiça social. Rio de Janeiro: Fundação Getúlio Vargas, 1999.

DUL, J.; WEERDMEESTER, B.Ergonomia prática. São Paulo: Edgard Blucher, 1995. $147 \mathrm{p}$.

FARIAS, F.A.C. Dimensionamento de pessoal de enfermagem para prontosocorro especializado em afecções cardiovasculares. Tese (Doutorado). Universidade de São Paulo, São Paulo, 2003, 257 p.

FARIAS, S. N. P. Riscos no trabalho e agravos à saúde do trabalhador de enfermagem em Centro Municipal de Saúde. Dissertação (Mestrado) - Escola de Enfermagem Anna Nery/UFRJ, Rio de Janeiro, 1999.

Qualidade de vida no trabalho: um enfoque para enfermagem em centro municipal de saúde. 2004. Tese (Doutorado) - Escola de Enfermagem Anna Nery/UFRJ, Rio de Janeiro, 2004.

; MAURO, M. Y. C.; ZEITOUNE, R. C. G. Questões legais sobre a saúde do trabalhador de enfermagem. Rev. Enfermagem UERJ, Rio de Janeiro, v. 8, n. 1, p. 28-32, janeiro/junho 2000.

FERREIRA, A. S. Competências gerenciais para unidades básicas do Sistema Único de Saúde. Ci. \& Saúde Coletiva, Rio de Janeiro, v. 9, n. 1, p. 69-76, 2004.

FERREIRA, L. L.; DONATELLI, S. Ergonomia: o que há para se ler em português. Ação Ergonômica, Rio de Janeiro, v. 1, n. 2, p. 25-34, 2001.

FREITAS, C. M. Dos limites e das possibilidades das micronegociações para o 
replanejamento do trabalho (Debate sobre o artigo de Leny Sato). Cad. Saúde Pública, Rio de Janeiro, v. 18., n. 5, p. 1147-1166, setembro/outubro 2002.

GONÇALVES, R. B. M. Tecnologia e organização social das práticas de saúde: características tecnológicas do processo de trabalho na rede na estadual de centros de saúde de São Paulo. São Paulo: Hucitec, 1994. 278 p.

GRANDJEAN, E. Manual de ergonomia: adaptando o trabalho ao homem. Porto Alegre: Artes Médicas, 1998. 338 p.

GUÉRIN, F.; LAVILlE, A.; DANIELlOU, F.; DURAFFOURG, J.; KERGUELEN , A. Compreender o trabalho para transformá-lo: a prática da ergonomia. São Paulo: Edgard Blucher, 2002. 200 p.

IBERMUTUAMUR, R. A. Manual de ergonomia. Madrid: Editorial y Producción. 2000. 557 p.

IIDA, I. Ergonomia: projeto e produção. São Paulo: Edgard Blucher, 1990. 465 p.

INTERNATIONAL ERGONOMICS ASSOCIATION-IEA. Reunião do conselho científico. San Diego, USA, , julho 2000.

IOSSI, M. A. O envolvimento dos profissionais de saúde no município de Guarulhos na assistência às crianças vítimas de violência doméstica: um caminhar necessário. 2004. 143 f. Tese (Doutorado) - Escola de Enfermagem de Ribeirão Preto/USP, Ribeirão Preto, 2004.

KALINOWSKI, C. E. O trabalho da enfermeira na rede básica de saúde. In: Experiência de enfermeiros da Secretaria Municipal de Saúde de Curitiba: subsídios para a sistematização do processo de cuidar em saúde coletiva. Curitiba: Associação Brasileira de Enfermagem, ABEn, 2004. 316 p.

LAURELL, A. C.; NORIEGA, M. Processo de produção e saúde-trabalho e desgaste operário. São Paulo: Hucitec, 1989. 333 p.

LAVILLE, A. Ergonomia. São Paulo: EPU, 1977. 99 p.

LEOPARDI, M. T. Introdução. In: . O Processo de trabalho em saúde: organização e subjetividade. Florianópolis: Papa-Livros, 1999a. 176 p.

Papa-Livros, 1999 b.

Trabalho na saúde: organização e subjetividade. Florianópolis: 
LIMA, F. P. A. Ergonomia, ciência do trabalho, ponto de vista do trabalho:a ciência do trabalho numa perspectiva histórica. Ação Ergonômica, Rio de Janeiro, v. 1 , n. 2, p. 35-45, agosto 2001 .

LOPES, G. T.; SPINDOLA, T.; MARTINS, E. R. C. O adoecer em Enfermagem segundo seus profissionais: estudos preliminares. Rev. Enfermagem UERJ, Rio de Janeiro, v. 4, n. 1, p. 9-18, maio 1996.

MAGALHÃES, A.M.; DUARTE.E.R.M.;MOURA,G.M.S.S. Estudo das variáveis que participam do dimensionamento de pessoal de enfermagem em hospitais de grande porte. Rev. gauch. enfermagem;16(1/2):5-16, jan-dez. 1995.

MAGALHÃES, R. A. S.; MÁSCULO, F. S. Identificação de riscos ergonômicos no posto de trabalho de médico-cirurgiões em um hospital universitário. Bahia: Associação Brasileira de Ergonomia-ABERGO, 2000. p. 22-33.

MARTINEZ, M. C.; PARAGUAY, A. I. B. B.; LATORRE, M. R. D. O. Relação entre satisfação com os aspectos psicossociais e saúde dos trabalhadores. Rev. Saúde Pública, São Paulo, v. 38, n. 1, p. 55-61, fevereiro 2004.

MARZIALE, M. H. P. Estudo da fatiga mental em enfermeiras atuantes em instituição hospitalar com esquema de trabalho em turnos alternantes. 1990. Dissertação de Mestrado - Escola de Enfermagem de Ribeirão Preto/USP, Ribeirão Preto, 1990.

Condições ergonômicas da situação de trabalho do pessoal de enfermagem em uma unidade de internação hospitalar. 1995. Tese (Doutorado) - Escola de Enfermagem de Ribeirão Preto/USP, Ribeirão Preto, 1995.

MARZIALE, M. H. P. Abordagem ergonômica do trabalho de erfermagem. 2000. 149 f. S Tese (Livre-docência) - Escola de Enfermagem de Ribeirão Preto/USP, Ribeirão Preto, 2000.

; CARVAlHO, E. C. Condições ergonômicas do trabalho de enfermagem em unidade de internação de cardiologia. Rev. Latino-am. Enfermagem, Ribeirão Preto, v. 6, n. 1, p. 99-117, janeiro 1998.

MARX, K.; ENGELS, F. A ideologia alemã. 11ª ed. São Paulo : Hucitec, 1999.

MATTOS, U. A. O. Introdução ao estudo da questão saúde e trabalho. Rio de 
Janeiro.1997. Livreto Sociedade e Condições de Trabalho.

MAURO, M. Y. C. Fadiga e aspectos ergonômicos do trabalho de enfermagem. Rev. Bras. Enfermagem, Distrito Federal, n. 29, p. 7-18, 1976.

; CUPELLO, A. J. O trabalho de enfermagem hospitalar: uma visão ergonômica. In: ANAIS ABERGO, Gramado, 2 a 6 de setembro 2001. Anais. Gramado: ABERGO, 2001.

; MUZI, C. D.; GUIMARÃES, R. M.; MAURO, C. C. C. Riscos ocupacionais em saúde. Rev. Enfermagem UERJ, v. 12, p. 338-345, 2004.

MENDES, E. V. Distrito sanitário: o processo social de mudança das práticas sanitárias do sistema único de saúde. São Paulo: Hucitec, 1995. 310 p.

MERHY, E. E. Saúde: a cartografia do trabalho vivo. São Paulo: Hucitec, 2002. $189 \mathrm{p}$.

MIELNIK, I.Higiene mental do trabalho. São Paulo:Artes Médicas, 1976. 185 p.

MINAYO, M. C. S. Violência social sob a perspectiva da saúde pública. Cad. Saúde Pública, v. 10, supl. 1, p. 7-18, 1994.

; SOUZA, E R. de. Violência para todos. Cad. Saúde Pública, v. 9, n.1, p. 65-78, janeiro/março 1993.

; DESLANDES, S. F. A complexidade das relações entre drogas, álcool e violência. Cad. Saúde Pública, v. 14, n.1, p.35-42, janeiro/março 1998.

MUROFUSE, N. T. O adoecimento dos trabalhadores de enfermagem na Fundação Hospitalar do Estado de Minas Gerais: reflexo das mudanças do mundo do tabalho. 2004. 298 f. Tese (Doutorado) - Escola de Enfermagem de Ribeirão Preto/USP, Ribeirão Preto, 2004.

, N. T.; ABRANCHES, S. S.; NAPOLEÃO, A. A. Reflexões sobre estresse e burnout e a relação com a enfermagem. Rev. Latino-am. Enfermagem, v. 13, n. 2, p. 255-61, março/abril 2005.

NAPOLEÃO, A. A.; ROBAZZI, M. L. C. C. Acidentes de trabalho e subnotificação entre trabalhadores de enfermagem. Rev. Enfermagem UERJ, Rio de Janeiro, v. 11, p. 59-63, 2003.

NASCIMENTO, G. M. Estudo do absenteísmo dos trabalhadores de enfermagem em uma unidade básica e distrital de saúde do município de Ribeirão Preto - SP. 2003. Dissertação (Mestrado) - Escola de Enfermagem de 
Ribeirão Preto/USP, Ribeirão Preto. 2003.

NEMES, M. I. B. Ação programática em saúde:referenciais para análise da organização do trabalho em serviços de atenção primária. Espaço Saúde, v. 2, n. 2, p. 40-45, 1990.

NEMES FILHO, A. A unidade básica de saúde e o sistema de saúde. In: Saúde do adulto: programas e ações na unidade básica. São Paulo: Hucitec, 2000. 289 p.

NEVES, E. P. Cuidando e confortando: uma estratégia para a saúde do trabalhador. Rev. Enfermagem UERJ, Rio de Janeiro, v. 10, n. 2, p.133-137, maio/agosto 2002.

NOGUEIRA, R. P. As dimensões do trabalho em saúde In: Saúde, trabalho e formação profissional. Rio de Janeiro: FIOCRUZ, 1997. p. 71- 76.

OFFICE FOR SUBSTANCE ABUSE PREVENTION (OSAP). Prevention plus III assessing alcohol and other drugs prevention programs at school and community level. Atlanta: US Department of Health and Human Services, 1991.

OGUISSO, T.; SCHMIDT, M. J. O exercício da enfermagem: uma abordagem ético-legal. São Paulo: LTr, 1999. 232 p.

OKAMOTO, V. A.; SANTOS, U. P. Outros efeitos do ruído no organismo. In: SANTOS, U. de P. (Org.). Ruído: riscos e prescrição. 2. ed. São Paulo: Hucitec, 1996.

OLIVEIRA, E. B.; LISBOA, M. T. L. Análise da produção científica da vertente saúde do trabalhador de enfermagem: subjetividade e trabalho. Rev. Enfermagem UERJ, v. 12, p. 24-29, 2004.

ORGANIZAÇÃO INTERNACIONAL DO TRABALHO. ORGANIZAÇÃO MUNDIAL DA SAÚDE (OIT/OMS). Reunión conjunta sobre condiciones de trabajo y de vida del personal de enfermeria. Genebra, 1976.

. Empleo y condiciones de trabajo y de vida del personal de enfermeria. In: CONFERENCIA INTERNATIONAL DEL TRABAJO, 63, Informe 4, n. 1 e 2. Ginebra, 1977.

. CONSEJO INTERNACIONAL DE ENFERMERAS (CIE). ORGANIZACION MUNDIAL DE LA SALUD (OMS). INTERNACIONAL DE SERVICIOS PUBLICOS (ISP). Programa conjunto sobre la violencia laboral 
en el sector de la salud. Ginebra, 2002.

ORGANIZACION MUNDIAL DE LA SALUD. Informe mundial sobre la violencia y la salud. Genebra, 2002.

PALACIOS, M. Violência no ambiente de trabalho no setor saúde da cidade do Rio de Janeiro: trabalhadores da saúde - vítimas e algozes. Ci. \& Saúde Coletiva, Rio de Janeiro, v. 8, supl. 2, p. 214-220, 2003.

PAVANI, L.M.D. Análise do dimensionamento de pessoal de enfermagem na unidade de pós-operatório de cirurgia cardíaca em um hospital universitário em cardiologia. Dissertação (Mestrado). São Paulo. Universidade de São Paulo. 2000. $133 \mathrm{p}$.

PICALUGA, I. F. Saúde e trabalho. In: Saúde e trabalho no Brasil. São Paulo: Ibase;Vozes, 1983. $110 \mathrm{p}$.

RICHTER,A.M.;VAGHETTI,H.H.SOTRES,R.M. Dimensionamento da área física e pessoal de enfermagem na unidade de centro obstétrico em relação ao número de pacientes atendidas no serviço de obstetrícia do Hospital de Clínicas de Porto Alegre. Rev. gauch. hosp.; 10(2):71-81,1982.

RIO DE JANEIRO (Cidade). Secretaria de Saúde do Estado do Rio de Janeiro. Informe ao gestor. Regionalização de Estado de Saúde Disponível em: http://www.saude.rj.gov.br/Secretaria/servicos saude.shtml. Acessado em: 24 agosto 2005 .

ROBAZZI, M. C. C.; MARZIALE, M. H. P. Alguns problemas ocupacionais decorrentes do trabalho de enfermagem no Brasil. Rev. Bras. Enfermagem, v. 52, n.3, p. 331-338, julho/setembro 1999.

ROCHA, C. M. V.da et al. Manual de rede de frio. 3. ed. Brasília: Ministério da Saúde: Fundação Nacional de Saúde, 2001. 80 p

ROUQUAYROL, M. Z.; ALMEIDA FILHO, N. A. Epidemiologia e saúde. Rio de Janeiro: Medsi, 1999. 569 p.

ROYAS, A. D. V.; MARZIALE, M. H. P. A situação de trabalho do pessoal de enfermagem no contexto de um hospital argentino: um estudo sob a ótica da ergonomiA. Rev. Latino-Am. Enfermagem, Ribeirão Preto, v. 9, n. 1, p.102-108. janeiro 2001. 
SAMPAIO, L. R.; FIGUEIREDO, V. C. Correlação entre o índice de massa corporal e os indicadores antropométricos de distribuição de gordura corporal em adultos e idosos. Rev. Nutrição, Campinas, v. 18, n. 1, p. 53-61, janeiro/fevereiro 2005.

SANTIAGO, F. R.; ARBONA, R. G. Manual de prevención de riesgos laborales. Madrid: Ibermutuamur, 2000. 684 p.

SANTOS JÚNIOR, E. A. D; DIAS, E. C. violência no trabalho: uma revisão da literatura. Rev. Bras. Med. Trab., Belo Horizonte, v. 2, n. 1, p. 36-54, janeiro/março 2004.

SCHIMIDT,M.J. Natureza das condições de trabalho da enfermagem. Rev. Paul. Enf., São Paulo, v.4, n.3, p.89-94, 1984.

SCHRAIBER, L. B.; NEMES, M. I. B.; MENDES, R. B. Saúde do adulto: programas e ações na Unidade Básica. São Paulo: Hucitec, 2000. 296 p.

SILVA, A.L. Céu e inferno: metáforas no processo do cuidado entre os cuidadores. In: A enfermagem e a arte de cuidar. Florianópolis: Editora UFSC, 1999. $264 \mathrm{p}$.

SILVA, G. Enfermagem profissional. São Paulo: Cortez, 1989. 143 p.

SILVA, L. D. da. A educação revelando os riscos ocupacionais no trabalho da enfermagem intensivista. 2000. $197 \mathrm{f}$. Tese (Doutorado em Enfermagem) - Escola de Enfermagem Anna Nery, Universidade Federal do Rio de Janeiro, Rio de Janeiro, 2000 .

SILVA, R. C. G.; FELLI, V. E. A. Um estudo comparativo sobre a identificação dos riscos ocupacionais por trabalhadores de enfermagem de duas unidades básicas de saúde do município de São Paulo. Rev. Enfermagem USP, São Paulo, v. 36, n. 1, p. $18-24,2002$.

SILVA, E. M.; NOZAWA, M. R.; SILVA, J. C. Práticas das enfermeiras e políticas de saúde pública em Campinas, São Paulo, Brasil. Cad. Saúde Pública, v. 17, n. 4, p. 989-998, julho/agosto 2001.

SLUCHACK, T. J. Ergonomics: origins, focus, and implementation considerations. AAOHNJ, v. 40, n. 3, p. 105-112, março 1992.

STACCIARINI, J. M.; TRÓCOLI, B. T. O estresse na atividade ocupacional do enfermeiro. Rev. Latino-am. Enfermagem, Ribeirão Preto, v. 9, n. 2, p. 17-25, março 2001. 
VELAZQUEZ, F. F.; LOZANO, G. M.; ESCALANTE, J. N.; RIPOLLÉS, M. R. Manual de ergonomia. Madrid: Editorial Mapfre, 1995. 619 p.

VIDAL, M. C. R. Análise focal e pré-diagnóstico. Rio de Janeiro: Curso de Especialização em Ergonomia-CESERG/COPPE/UFRJ, 2000.

. Introdução à ergonomia. Rio de Janeiro: Curso de Especialização em Ergonomia-CESERG/COPPE/UFRJ, 2001a.

Análise focada. Rio de Janeiro: Curso de Especialização em ErgonomiaCESERG/COPPE/UFRJ, 2001b.

. Ergonomia na empresa-útil, prática e aplicada. Rio de Janeiro: Ed. Virtual Científica, 2001c. 260 p.

; SETTI, M. E. C. Ergonomia e segurança do trabalho. Rio de Janeiro: Ação Ergonômica, v. 1, n. 2, p. 13-24, 2001.

VOLTA REDONDA (Cidade). Secretaria de Saúde . Disponível em: http://www.portalvr.com/governo/secretarias.php . Acessado em: 24 agosto 2005.

WISNER, A. A inteligência do trabalho: textos selecionados de ergonomia. São Paulo: UNESP/FUNDACENTRO, 1994. 191 p.

WITT, R. R. As competências da enfermeira na atenção básica: contribuição à construção das funções essenciais de saúde pública. 2005. 336 f. Tese (Doutorado) - Escola de Enfermagem de Ribeirão Preto/USP, Ribeirão Preto, 2005.

WUNSCH FILHO, V. Saúde do trabalhador como liberdade (Debate sobre o artigo de Leny Sato). Cad. Saúde Pública, Rio de Janeiro, v. 18, n. 5, p. 11471166, setembro/outubro 2002.

ZAPATER, A. R.; SILVEIRA, D. M.; VITTA, A.; PADOVANI, C. R.; SILVA, J. C. P. Postura sentada: a eficácia de um programa de educação para escolares. Ci. \& Tecnol., Rio de Janeiro, v. 9, n. 1, p. 191-199, 2004. 
ZEITOUNE, R. C. G. Desconforto lombar e as variáveis cinemáticas da postura do profissional de enfermagem. 1996. 159 f. Tese (Doutorado) - Escola de Enfermagem Anna Nery/UFRJ, Rio de Janeiro, 1996. 


\section{APÊNDICE A}

\section{CONSENTIMENTO LIVRE E ESCLARECIDO}

"Estudo ergonômico da situação de trabalho de enfermagem em unidades básicas de saúde"

Responsável: Sueli Soldati Abranches

Doutoranda em Enfermagem/USP

Orientadora: $\mathrm{Dr}^{\mathrm{a}}$ Maria Helena Palucci Marziale

Estamos realizando um estudo sobre a situação do trabalho em enfermagem, que se propõe a identificar e analisar as condições de trabalho da equipe de enfermagem. Para isto, precisamos que você responda algumas perguntas que faremos por meio de uma entrevista.

As informações que você nos der vai ajudar no diagnóstico de quais as condições em que você trabalha e levantar elementos que necessitam ser modificados para melhorar essas condições em que o trabalho é realizado. Você poderá participar ou não da pesquisa e tem o direito de se recusar a responder qualquer uma das questões sem que isto prejudique sua atuação profissional. Também poderá solicitar esclarecimentos quando sentir necessidade e ainda poderá desistir da participação em qualquer momento que assim desejar .

Será garantido o sigilo e o anonimato das informações que nos der e qualquer dúvida você poderá entrar em contato com a pesquisadora no telefone (24)33431491, no endereço Rua Silva Ramos $n^{0}$ 18, Jardim Normândia-Volta Redonda/RJ.

Esperamos que os resultados desta pesquisa ajudem na melhoria das condições de trabalho desta unidade e de outras unidades da rede básica de saúde.

Desde já agradecemos a sua colaboração.

Sueli Soldati Abranches.

\section{DECLARAÇÃO DE CONSENTI MENTO}

Tendo lido as informações dadas sobre a pesquisa e tendo tido a oportunidade de fazer perguntas, ter recebido respostas que me deixaram satisfeito e ter entendido que tenho o direito de não responder a este questionário, sem que isto traga conseqüências para mim, aceito participar da pesquisa

Volta Redonda,

Assinatura do participante

$\mathrm{RG}$
Assinatura do pesquisador Sueli Soldati Abranches. RG M.619.8885-SSP/MG 


\section{APÊNDICE B \\ ROTEIRO DE ENTREVISTA COM O GERENTE DO SERVIÇOS DE ENFERMAGEM \\ (Adaptado de MARZIALE, 1995)}

- Iniciais do entrevistado:

- Data. / / Horário de início: término:

\section{Dados sobre a Unidade Básica de Saúde - UBS}

Iniciais:

Especialidades atendidas:

Número de trabalhadores/categorias:

\section{Características do serviço de Enfermagem}

Qual o número de funcionários de acordo com cada categoria?

Como se organiza hierarquicamente o serviço? (organograma)

Quais as atividade prescritas para as diferentes categorias de profissionais da Enfermagem?

Como se organiza a divisão de trabalho de Enfermagem? (número de pessoal $\mathrm{X}$ número de usuários, divisão de tarefas e supervisão)

Como são os horários de trabalhos? (pausas)

Como é a rotatividade do pessoal de Enfermagem na UBS? (baseado no ano anterior, qual o número de admissões e demissões) 
Qual é a incidência de absenteísmo mensal do pessoal de Enfermagem?

Qual o motivo alegado pelos trabalhadores como justificativa das faltas?

Quais as causas de absenteísmo registradas? (levantamento epidemiológico)

Quais os benefícios oferecidos aos trabalhadores?

Existe algum treinamento para o pessoal de Enfermagem? Se afirmativo, como e quando é realizado?

Existe algum problema interno ou externo que interfere ou interferiu no serviço de Enfermagem? (exemplo: ritmo de trabalho, local, horário, material, organização etc.)

Existe alguma unidade que apresenta algum tipo de problema com o pessoal de Enfermagem? Qual a unidade? Qual o problema?

O trabalho tem interferido na saúde do pessoal de enfermagem?

Considera que todos desta unidade enfrentam ou estão submetidos à violências? Quais tipos?

Quem são as vítimas? Quem são os agressores? Como lidam com estas situação?

Gostaria de fazer alguma colocação adicional? 


\section{APÊNDICE C \\ ROTEIRO DE ENTREVISTA COM O PROFISSIONAL DE ENFERMAGEM NA UBS \\ (Adaptado de MARZIALE, 1995)}

Data:

Início:

Término:

- Dados de Identificação:

Dados antropométricos

Peso

Altura

Altura ao nível do cotovelo

- Idade: anos

- Sexo:

- Estado Civil

( ) Solteiro

( ) Casado

( ) Viúvo

( ) Outro

especificar

- Escolaridade:

( ) Primeiro grau incompleto

( ) Primeiro grau completo

( ) Segundo grau incompleto

( ) Segundo grau completo

( ) Superior incompleto

( ) Superior completo 
- Categoria profissional:

( ) Auxiliar de enfermagem

( ) Técnico de enfermagem

- Experiência Profissional

- Tempo de trabalho na enfermagem

anos

- Tempo que trabalha nesta unidade:

- Salário

- Salário Mensal (em salários mínimos)do trabalhador nesta UBS

( ) de 1 a 2.

( ) de 2 a 3

( ) de 3 a 4

( ) de 4 a 5

(valor do salário mínimo $=\mathrm{R} \$$ )

- Composição de família:

(quantos elementos da família que residem em sua casa, além de você?)

especificar o número

Renda Familiar (em salários mínimos):

( ) de 1 a 2

( ) de 2 a 3

( ) de 3 a 4

( ) de 4 a 5

( ) de 5 a 6 
- Tem outra ocupação remunerável:

( ) Não ( ) Sim

especificar tipo, local, horário de trabalho

\section{- Satisfação no Trabalho}

- Em relação ao seu trabalho você está?

( ) Satisfeito

$$
\text { por quê? }
$$

( ) Insatisfeito

$$
\text { por quê? }
$$

\section{- Qualidade de Vida}

- Moradia:

( ) Própria quitada

( ) Própria financiada

( ) Alugada

( ) Emprestada

( ) Outros

especificar

- Transporte:

qual (is) o (s) meio (s) transporte que utiliza para vir ou ir ao trabalho?

( ) Carro

( ) Ônibus

( ) Bicicleta

( ) Vai a pé

( ) Outros

especificar 
- Tempo em minutos que você gasta com o transporte para vir a UBS minutos)

- Lazer:

- Tem período destinado ao lazer?

( ) Não

( ) $\operatorname{Sim}$

especificar o forma de lazer

freqüência

- Alimentação:

- Seu horário destinado a alimentação é

( ) Regular

( ) Irregular

- Tem disponibilidade de tempo para realizar sua alimentação?

( ) Não

( ) $\operatorname{Sim}$

Comentar

\section{- Condições de Saúde}

- Possui algum problema de saúde?

( ) Não

( ) $\operatorname{Sim}$

especificar qual

desde quando

motivo que atribui a doença

se usa algum medicamento, especificar qual

- Já teve algum problema de saúde provocado pelo trabalho de enfermagem que 
executa neste setor?

( ) Não

( ) $\mathrm{Sim}$

qual?

quando?

motivo?

- Nestes últimos 12 meses sofreu algum acidente relacionado ao trabalho neste setor?

( ) Não

( ) $\operatorname{Sim}$

qual?

quando?

onde?

motivo que atribui ao acidente

se teve afastamento, o $\mathrm{n}^{\mathrm{o}}$ de dias

-Já sofreu algum tipo de violência no trabalho

( ) Não

( ) $\operatorname{Sim}$

( ) Agressão física de usuário

( ) Agressão verbal de usuário

( ) Relacionamento com os colegas de enfermagem

( ) Relacionamento com outros profissionais de saúde 
( ) Relacionamento com a chefia

( ) Em visitas domiciliares

( ) Em situações de emergências

( ) Outros. Quais?

- Você percebe algum tipo de violência advinda do trabalho

( ) Não

( ) $\operatorname{Sim}$

( ) Espaços de trabalho

( ) Sistema de segurança inadequado

( ) Outros. Quais?

- Como é o seu sono?

( ) Não tem problema

( ) Tem problemas

especificar

\section{- Disposição para o trabalho}

- Fisicamente trabalhando nesta unidade sente-se:

( ) Bem disposto

por quê?

( ) Mal disposto

$$
\text { por quê? }
$$

( ) Outros

especificar como e porque

- Mentalmente sente-se:

( ) Cansado

$$
\text { por quê? }
$$

( ) Bem 
( ) Outro

\section{especificar o porquê}

- Hábitos:

- Você possui hábitos de :

( ) Não fumar

( ) Fumar

o que? quantidade por dia?

( ) Não ingerir bebida alcoólica

( ) Ingerir bebida alcoólica

qual? quantidade por dia?

( ) Drogas

especificar

( ) Outro

especificar

\section{- Atividade de Trabalho}

- A quantidade de tarefas que realiza em cada jornada de trabalho é:

( ) Excessiva

( ) Adequada

( ) Outro especificar

- Como considera a distribuição das tarefas quanto a quantidade:

( ) São adequados

( ) São inadequados 
- Para realizar suas tarefas há esforço físico significativo?

( ) Não

( ) $\operatorname{Sim}$

em qual (is) tarefa(s), por quê?

- É necessário concentrar a atenção par executar suas tarefas?

( ) Não

( ) $\operatorname{Sim}$

em qual(is) atividade(s), por quê?

- Como você considera suas tarefas?

( ) Normais

( ) Repetitivas

( ) Imprevisíveis

( ) Monótonas

( ) Outra

especificar

\section{- Educação em Serviço}

- Quando você iniciou suas atividades nesta unidade recebeu treinamento para executar as tarefas?

( ) Não

( ) $\operatorname{Sim}$

- Se afirmativo esse treinamento foi: $(\quad$ )

1- Suficiente

2- Insuficiente

3- Outro especificar

- Recebe educação em serviço?

( ) Não

( ) $\operatorname{Sim}$

-Quando? Sobre que temas? 
É suficiente para seu desempenho? ( ) Sim

( ) Não

\section{- Material}

- Os materiais que utiliza para executar suas tarefas são? $(\quad)(\quad)$

( ) Adequados na qualidade

( ) Inadequados na qualidade

especificar quais

( ) Adequados na quantidade

( ) Inadequados na quantidade

especificar quais

( ) Outro

especificar quais

- Você usa freqüentemente usa equipamentos de proteção individual- EPI para execução de suas atividades?

( ) Não

por quê?

( ) $\mathrm{Sim}$

- Os EPIs que você usa são confortáveis ?

( ) Não

por quê?

( ) $\operatorname{Sim}$

- Ambiente de Trabalho

- Há algum risco ambiental nesta unidade?

( ) Não

( ) $\operatorname{Sim}$

Qual?

( ) possibilidade de contaminação por agentes biológicos

( ) ruído ambiental

( ) agentes químicos 
( ) temperatura elevada

( ) umidade

( ) ventilação inadequada

( ) iluminação inadequada

( ) mobiliário inadequado

( ) equipamentos inadequados

- O Ambiente físico de trabalho lhe permite conforto?

( ) Não por quê?

( ) $\operatorname{Sim}$

- Como considera os espaços do ambiente de trabalho?

( ) Adequados

( ) Inadequados por quê?

( ) Outros especificar

- A disposição dos equipamentos é

( ) Adequada

( ) Inadequada por quê?

- Como considera a temperatura do ambiente da unidade?

( ) Adequada

( ) Inadequada

porquê?

- Como considera a iluminação do ambiente?

( ) Adequada

( ) Inadequada por quê?

- Organização do trabalho

- Qual a sua carga horária de trabalho ? 
- O que acha do esquema fixo de horários?

( ) Adequado

( ) Inadequado por quê?

( ) Não existe pausa.

- O que acha do tempo de pausas no trabalho ?

( ) Adequado

( ) Inadequado

por quê?

- Você rotineiramente falta ao trabalho?:

( ) Não:

( ) Sim:

motivo, especificar a freqüência

- Quais os motivos que o levam a faltar ao trabalho?

\section{- Supervisão}

- Como é a supervisão do trabalho nesta unidade ?

( ) Adequada

( ) Inadequada

por quê? sugestões 
- Tem alguma dificuldade ou problema em trabalhar nesta unidade?

( ) Não

por quê?

( ) $\mathrm{Sim}$

por quê? 


\section{APÊNDICE D}

AMBIENTE FÍSICO DE TRABALHO

(Adaptado de MARZIALE, 1995)

Local

Data

1- Há fatores de riscos ambientais potenciais?

Químicos: ( ) Não ( ) Sim

Especificar:

Físicos: ( ) Não ( ) Sim

Especificar:

Biológicos: ( ) Não （ ) Sim

Especificar:

Ergonômicos: ( ) Não （） Sim

Especificar: 
2-Aferição da Temperatura

- Condições climáticas do dia:

. Temperatura: máxima: mínimo: média:

. Unidade Relativa: : máxima: mínimo:

. Condições do tempo:

Leituras :

\begin{tabular}{|c|c|c|}
\hline Temperatura & Leitura & \\
\hline Primeiro pavimento & & Segundo pavimento \\
\hline Posto de Enfermagem & & Posto de Enfermagem \\
\hline Hora & & Hora \\
\hline \multirow{3}{*}{\multicolumn{3}{|c|}{$\begin{array}{l}\text { Termômetro } \\
\text { de Bulbo } \\
\text { Úmido }\end{array}$}} \\
\hline & & \\
\hline & & \\
\hline \multicolumn{3}{|l|}{ Termômetro de } \\
\hline Globo & & \\
\hline
\end{tabular}

- Características do trabalho:

. Ambiente de trabalho :

$$
\begin{aligned}
& \text { interno }(\quad) \\
& \text { externo com carga solar }(\quad)
\end{aligned}
$$

Regime de trabalho:

$$
\begin{aligned}
& \text { contínuo ( }) \\
& \text { intermitente }(\quad)
\end{aligned}
$$

Caso intermitente, para 1 hora de tempo trabalho descanso de minutos tempo 
- Tipo de atividade :

$$
\begin{aligned}
& \text { leve }(\quad) \\
& \text { moderada }(\quad) \\
& \text { pesada }(\quad)
\end{aligned}
$$

1- Iluminação

- Quais as tarefas que têm maiores exigências visuais?

- É necessário alto nível de iluminação?

( ) Não ( ) Sim

Onde/para quê?

- É necessário luz artificial geral ou local?

( ) Não ( ) Sim

Porquê?

- Aferição do iluminamento

- Leituras

\begin{tabular}{|l|l|}
\hline Local Hora & $\begin{array}{l}\text { Nível de iluminamento } \\
\text { nas condições de } \\
\text { trabalho (Lux) }\end{array}$
\end{tabular}


-Atividade:

- Nível mínimo de iluminamento exigido (Lux) através da legislação:

- Iluminação natural: (quantidade e dimensões)

Janelas ( )

Portas ( )

Outros ( )

- Cor das paredes:

- Altura do teto:

Iluminação

artificial:

- Tipo de lâmpadas:

- Número de lâmpadas:

- Situação encontrada:

2- Ruído

- Há sinais auditivos na unidade?

( ) Não ( ) Sim

3- Quais são e que características apresentam? 
4- Aferição do ruído:

5- Jornada diária de trabalho: horas

6- Fontes geradoras de ruído:

1.

2.

3.

7- leituras:

\begin{tabular}{|cc|}
\hline $\begin{array}{c}\text { Ruído tipo } \\
\text { contínuo/intermitente }\end{array}$ & Valor \\
\hline \\
\hline
\end{tabular}




\section{APÊNDICE E \\ POSTOS DE TRABALHO \\ (Adaptado de MARZIALE, 1995)}

\section{Postos de Trabalho:}

- Qual a planta física e suas respectivas dimensões?

- Qual as características (descrição e dimensão) dos mobiliários ?

- Quais as atividades executadas no posto de trabalho:

Os postos de trabalho apresentam dimensões compatíveis com as atividades executadas?

( ) não ( ) sim

Por quê?

- As posições dos equipamentos e/ou mobiliários permitem uma postura corporal satisfatória?

$(\quad)$ não $\quad(\quad) \operatorname{sim}$
Por quê?

- O arranjo físico dos equipamentos, mobiliários e/ou instrumentos oferecem riscos a saúde dos trabalhadores?

( ) não ( ) sim

Por quê?

- A altura das superfícies de trabalho são compatíveis com as dimensões dos trabalhadores, nas posições corporais adotadas?

( ) não ( ) sim

Por quê? 
- O acesso ao local prevê protocolos de segurança

( ) não ( ) sim

Por quê? Quais?

- Há dispositivos de segurança no local

( ) não ( ) sim

Por quê? Quais?

- Há protocolos de segurança para as visitas domiciliares

( ) não ( ) sim

Por quê? Quais?

- Existe grupo de apoio e/ou dinâmica de grupos (diálogos sobre os determinantes da violência no trabalho?

( ) não ( ) sim

Por quê? Quais?

Quais os EPI(s) necessários para a realização das tarefas? Para quê e quando?

As medidas dos EPI(s), são adequadas as medidas antropométricas de seus usuários?

( ) Não ( ) Sim

Porquê?

Os EPI(s) são apropriados às atividades a que se destinam?

( ) Não ( ) Sim

Porquê? 
Os trabalhadores utilizam os EPI(s) corretamente?

( ) Não ( )Sim

Porquê? 


\section{APÊNDICE F}

FOLHA DE REGISTRO DAS ATIVIDADES DE TRABALHO

(Adaptado de MARZIALE, 1995)

Data:

Turno:

Iniciais do Trabalhador de Enfermagem observado:

Atividades de trabalho executadas

Tempo gasto 


\section{APÊNDICE G}

\section{ROTINAS DE ENFERMAGEM DA UBS . SALA DE VACINAS}

\section{ORGANIZACAOO DA SALA}

1- PASSAR UM PANO COM ÁLCOOL A 70\% SOBRE A BANCADA;

2- FAZER A LETTURA DO TERMÓMETRO;

3- REGISTRAR O GRAU NO MAPA DA GELADEIRA;

4- RETIRAR OS GELOX E ACONDICIONAR NA CAIXA TÉRMICA COM O TERMÓMETRO DE CABO EXTENSOR NA TEMPERATURA IDEAL;

5. RETIRAR AS VACINAS E ACONDICIONAR NA CAIXA TĖRMICA, DEVIDAMENTE GUARNECIDA DE GELOX QUANDO A TEMPERATURA ESTIVER ENTRE 2 A $8^{\circ} \mathrm{C}$;

6- PROVIDENCLAR O SUPRIMENTO DO MATERIAL NA SALA: AGULHAS, SERINGAS, ALGODÃO COM ÁLCOOL, ALGODÃo SEM ÁLCOOL, TERMÓMETRO, RECIPIENTE PARA PÉRFURO CORTANTE ETC.

\section{RECEPCÃO DO PACIENTE NA SALA}

1- CUMPRIMENTAR O RESPONSAVVL;

2- ANALISAR O CARTÃO DE VACINAS:

3- AFERIR: O PESO, A ALTURA EA TEMPERATURA DA CRIANÇA;

4. REGISTRAR: NO PRONTUÁRIOE NO CARTÃO DE VACINAS;

5- INFORMAR A VACINA QUE SERÁ ADMINISTRADA;

6. ORIENTAR QUANTO AOS CUIDADOS PÓS-VACINAL;

7- REALIZAR A tÉCNICA dE VACINAÇÃo;

8. OBSERVAR O GRÁFico No CARTÃo pARA AVALLAR SE O MENOR É BP3 9 (EM

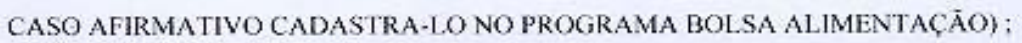

9. ENCAMINHAR À RECEPÇÃ O PARA O AGENDAMENTO DA CONSULTA DE PUERICULTURA;

10- AGENDAR O RETORNO NO CONTRA - ARQUIVO. 


\section{ANEXO A}
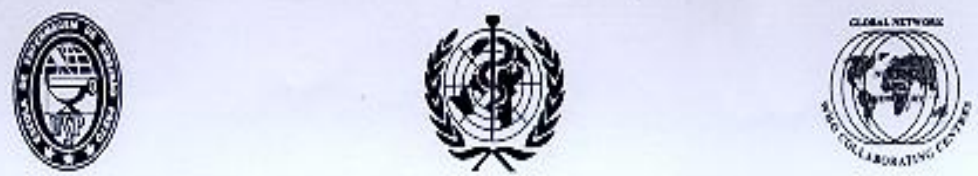

ESCOLA DE ENFERMAGEM DE RIBEIRĀO PRETO - UNIVERSIDADE DE SÃO PAULO

CENTRO COLABORADOR DA ORGANIZAÇÃO MUNDIAL. DA SAÚDE PARA O DESENVOLVIMENTO DA PESQUISA EM ENFERMAGEM

Avenda Eanderantes, 3900 - Compus Universitario - Rikeiráo Preto - CEP 14040902 - Sto Paulo - Brasil FAX $55-16 \cdot 633-327 ! / 55-16 \cdot 630-2561 /$ TEI EFONES: $55-16-633-0379 / 602 \cdot 3382$

Ribcirão Preto, 22 de agosto de 2003

Ilma Sra

Profa Dra Analice Silva Martins

Secretária da Saúde de Volta Redonda

Prezada Senhora

Vimos por meio deste, solicitar permissáo para coleta de dados junto as Unidades Básicas de Saúde deste Município, os quais serão utilizadas na tese de Doutorado da Enfermeira Sueli Soldati Abranches, docente do Centro Universitário de Barra Mansa, e aluna do Programa de Pós-Graduação da Escola de Enfermagen de Ribeirão Preto da Universidade de Săo Paulo.

Informamos que a pesquisa da referida pós-graduanda tem por objetivo "Analisar as condições ergonômicas do trabalho de enfermagem em unidades basicas de Saúde". Os resultados do estudo poderão contribuir para a melhoria das praticas de trabalho.

Atenciosamente

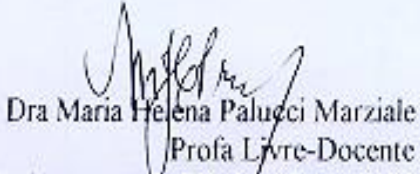

Escola de Enfermagem de Ribeináo Preto/USP

Orientadora do Programa de Pós-Graduação 


\title{
ANEXO B
}

ESTADO DO RIO DE JANEIRO

PREFEITURA MUMICIPAL OE VOLTA REDONDA

SECRETARIA MUNICIPAL DE SAÚDE

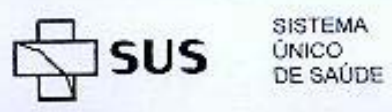

\section{DECLARACÃ O}

Declaro para os devidos fins que, autorizamos a realização nesta Secretaria Municipal de Saúde, da Pesquisa Intitulada " Análise Ergonômica do Trabalho de Enfermagem em Unidade Básica de Saúde de Volta Redonda - RJ, a ser realizada pela Enfermeira Sueli Soldati Abraches, sob a Coordenação da Prof. Dra. Maria Helena Palluci Marziale.

Volta Redonda, 26 de novembro de 2003.

\author{
Auweror \\ Analice Silva Martins \\ Secretaria Municipal de Saúde
}




\section{ANEXO C}

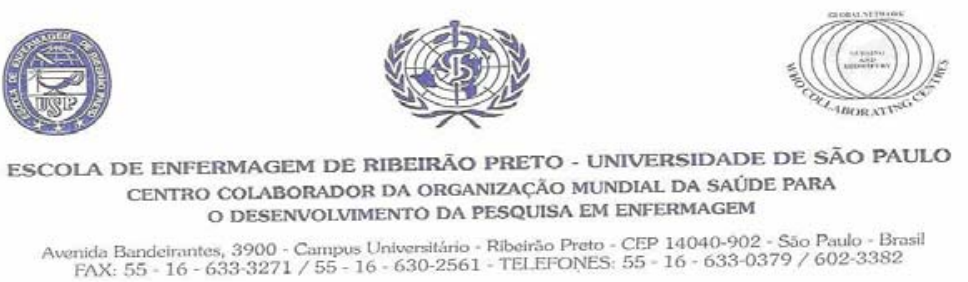

COMITÊ DE ÉTICA EM PESQUISA DA EERPIUSP

Of.CEP-EERP/USP - 049/2004

Ribeirăo Preto, 22 de julho de 2004

Prezada Senhora,

Comunicamos que o projeto de pesquisa, abaixo especificado, foi analisado e considerado APROVADO pelo Comitê de Ética em Pesquisa da foi analisado e considerado Ribeirāo Preto da Universidade de São Paulo, em sua $64^{\mathrm{a}}$ Reunião Ordinária, realizada em 21 de julho de 2004.

\section{Protocolo: $n^{\circ} 0445 / 2004$}

Projeto: Estudo Ergonômico da Situaçăo de Trabalho de Enfermagem em Unidades Básicas de Saúde

Pesquisadores: Maria Helena Palucci Marziale Sueli Soldati Abranches

Em atendimento à Resolução 196/96, deverá ser encaminhado ao Em atendim resultados, para CEP o relatório final da pesquisa e a publicasauer intercorrência ou a sua acompanhar

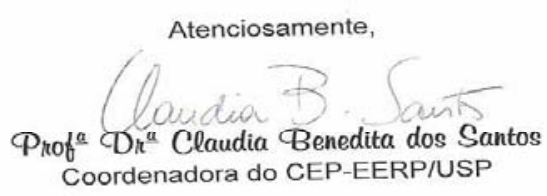

IIma. Sra.

Prof ${ }^{\circ} \mathrm{Dr}^{\circ}$ Maria Helena Palucci Marziale

Departamento de Enfermagem Geral e Especializada

Escola de Enfermagem de Ribeirão Preto - USP 